\title{
Szövettípusokra jellemző folyamatok az UV RESISTANCE LOCUS 8 (UVR8) UV-B fotoreceptor jelátviteli rendszerében
}

Doktori (Ph.D.) értekezés

Készítette: Bernula Péter

Témavezetők:

Prof. Dr. Nagy Ferenc

Dr. Viczián András

\begin{abstract}
Magyar Tudományos Akadémia
Szegedi Biológiai Kutatóközpont

Növénybiológiai Intézet

Foto- és Kronobiológiai Csoport
\end{abstract}

Szegedi Tudományegyetem

Természettudományi és Informatikai Kar

Biológia Doktori Iskola

Szeged

2018 


\section{TARTALOM}

Rövidítések jegyzéke 5

$\begin{array}{lr}\text { A dolgozatban előforduló gének listája } & 6\end{array}$

$\begin{array}{lc}\text { 1. BEVEZETÖ } & 8\end{array}$

$\begin{array}{lc}\text { 2. IRODALMI ÁTTEKINTÉS } & 10\end{array}$

2.1 Fényérzékelő fehérjék a növényekben 10

2.2 UV-B sugárzás: stresszor, vagy környezeti jel? 12

2.2.1 UV-B sugárzás, mint stressz faktor $\quad 12$

$\begin{array}{lll}\text { 2.2.2 UV-B sugárzás, mint jel } & 14\end{array}$

2.3 UVR8: a növényi UV-B fotoreceptor 15

2.3.1 Az UVR8 fotoreceptor felfedezése $\quad 15$

$\begin{array}{lll}\text { 2.3.2 Az UVR8 szerkezete } & 16\end{array}$

$\begin{array}{ll}2.4 \text { Az UVR8 által irányított jelátviteli utak } & 18\end{array}$

$\begin{array}{lll}\text { 2.4.1 Az UVR8 jelátvitel első lépései } & 18\end{array}$

2.4.2 Az UVR8 DNS-kötése 21

2.5 Az UVR8 kapcsolata egyéb jelátviteli útvonalakkal 22

2.5.1 Kapcsolat a fototropinok müködésével 22

2.5.2 Kapcsolat hormonális jelátviteli utakkal 23

$\begin{array}{lll}2.5 .3 & \text { Kapcsolat egyéb jelátviteli folyamatokkal } & 28\end{array}$

2.6 Az UVR8 jelátviteli hálózatának összefoglalása 29

2.7 Szövettípusoktól függő folyamatok a fényérzékelésben 30

2.7.1 Példák szöveti-, vagy szervi autonómiát mutató folyamatokra növényekben 30

3. CÉLKITÜZÉSEK

4. ANYAGOK ÉS MÓDSZEREK

4.1 Kísérleti anyagok és élőlények 35

4.1.1 Tápoldatok, táptalajok, antibiotikumok 35

4.1.2 Baktériumok 36

4.1.3 Növények 36

4.2 Növények nevelése és fénykezelése, kísérletek 37

4.2.1 Csíranövények nevelése és UV-B kezelése 37 
4.2.2 Felnőtt növények nevelése és UV-B kezelése 37

4.2.3 Hipokotil hossz és sziklevél felület meghatározása 39

4.2.4 UV-B irányba történő szárelhajlás vizsgálata felnőtt növényen 39

$\begin{array}{lll}\text { 4.2.5 Klorofill tartalom meghatározása } & 39\end{array}$

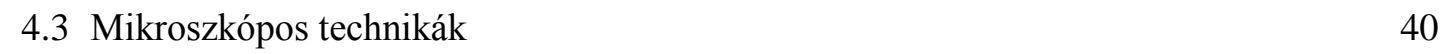

4.3.1 Metszetek készítése felnőtt növények virágzati szárából 40

4.3.2 Konfokális lézer-pásztázó mikroszkópia 40

4.3.3 Flavonoid detektálás 41

4.4 Molekuláris biológiai módszerek $\quad 42$

4.4.1 Molekuláris klónozás $\quad 42$

4.4.2 Növényi fehérjekivonatok készítése 42

4.4.3 Fehérjeszint meghatározás Western blot módszerrel 43

4.4.4 A transzkripciós szintek meghatározása 43

5. EREDMÉNYEK

5.1 Az UVR8 felhalmozódása különböző szövetekben 45

5.1.1 A ProUVR8:YFP-UVR8 transzgén expressziójának helye

Arabidopsis növényben $\quad 45$

5.1.2 Az YFP-UVR8 fehérjét különböző szövetekben kifejező transzgenikus növényi vonalak jellemzése $\quad 48$

5.2 A különböző szövetekben termelt YFP-UVR8 hatásai 50

5.2.1 Csíranövények kis intenzitású UV-B sugárzás hatására bekövetkező fotomorfogenikus válaszai $\quad 50$

5.2.2 Az UV-B sugárzás hatásai a felnőtt növények növekedésére 52

5.2.3 Az UV-B által indukált HY5 gén indukciója és HY5 fehérje termelődése 63

5.2.4 UV-B indukált HY5-függő és HY5-független gének transzkripciója 69

6. EREDMÉNYEK ÉRTÉKELÉSE

6.1 Az UVR8 fehérje előfordulása különböző szövetekben 74

6.2 A különböző szövetekben kifejezett UVR8 funkciói 74

6.2.1 Csíranövényeken vizsgált fotomorfogenikus UV-B-válaszok 74

6.2.2 Felnőtt növényekben vizsgált fotomorfogenikus és akklimációs folyamatok 76

$\begin{array}{lll}\text { 6.2.3 Fototropikus elhajlás UV-B sugárzás irányába } & 77\end{array}$

6.2.4 Az UVR8-függő flavonoid felhalmozódás szabályozása 79

6.3 UVR8 jelátvitel: génindukció 
6.3.1 A kalkon szintáz (CHS) génjének aktivitása UV-B sugárzás alatt 82

6.3.2 A HY5 és HYH UVR8-függő indukciója 82

6.3.3 Az ELIP2 és a PRR9 gén indukciója UV-B hatására 83

7. ÖSSZEFOGLALÁS

$\begin{array}{lr}\text { 8. SUMMARY } & 88\end{array}$

$\begin{array}{ll}8.1 \text { Introduction } & 88\end{array}$

$\begin{array}{ll}8.2 \text { Conclusions } & 89\end{array}$

SAJÁT KÖZLEMÉNYEK

IDÉZETT KÖZLEMÉNYEK

KÖSZÖNETNYILVÁNÍTÁS 103 


\section{Rövidítések jegyzéke}

$35 S$

ARF

AM

bHLH

bZIP

ChIP

CLSM

Col

DPBA

FAD

FMN

GFP

GUS

HRP

$\mathrm{kDa}$

LB

LOV

MAPK

MTHF

MS

NLS

PRC2

ROS

SCF

SDS

Tris

Tris- $\mathrm{HCl}$

UV-A/B

Ws

YFP karfiolmozaik vírus 35S RNS génjének promótere

Auxin Response Factor

Arabidopsis médium, növényi táptalaj

bázikus Helix-Loop-Helix (fehérjemotívum)

basic Leucine-Zipper (fehérjemotívum)

kromatin immunprecipitáció

konfokális lézer-pásztázó mikroszkóp

Arabidopsis thaliana (lúdfü) Columbia természetes ökotípusa

diphenylboric acid 2-amino ethyl ester (Naturstoffreagenz A, flavonoid festék)

Flavin Adenine Dinucleotide

Flavin Mononucleotide

Green Fluorescent Protein

$\beta$-glükuronidáz

torma peroxidáz

kilodalton

Luria-Bertani baktérium táptalaj

Light/Oxygene/Voltage (fehérjemotívum)

Mitogen-Activated Protein Kinase

flavin plus either methenyltetrahydrofolate

Murashige-Skoog növényi táptalaj

Nuclear Localization Signal (fehérjemotívum)

Polycomb Repressive Complex 2

Reactive Oxygen Species (reaktív oxigén formák)

SKP2/CULLIN/F-BOX E3 ubiquitin ligáz komplex

sodium dodecyl sulfate (nátrium-laurét-szulfát)

Trisz-(hidroximetil)-amino-metán

Trisz-(hidroximetil)-amino-metán hidroklorid sója

ultraibolya-A/B sugárzás

Arabidopsis thaliana (lúdfü) Wassilewskija természetes ökotípusa

Yellow Fluorescent Protein 


\section{A dolgozatban előforduló gének listája}

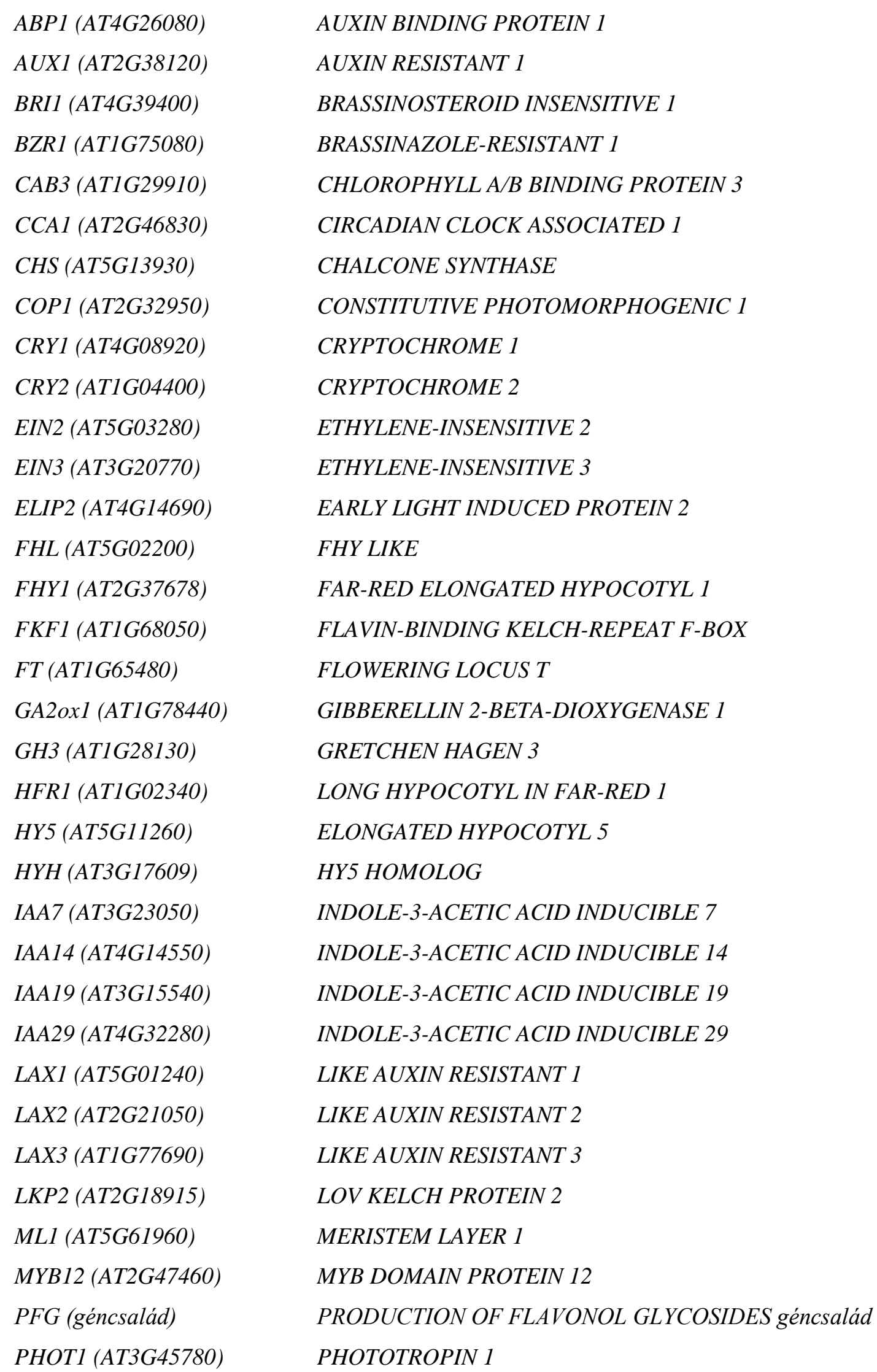




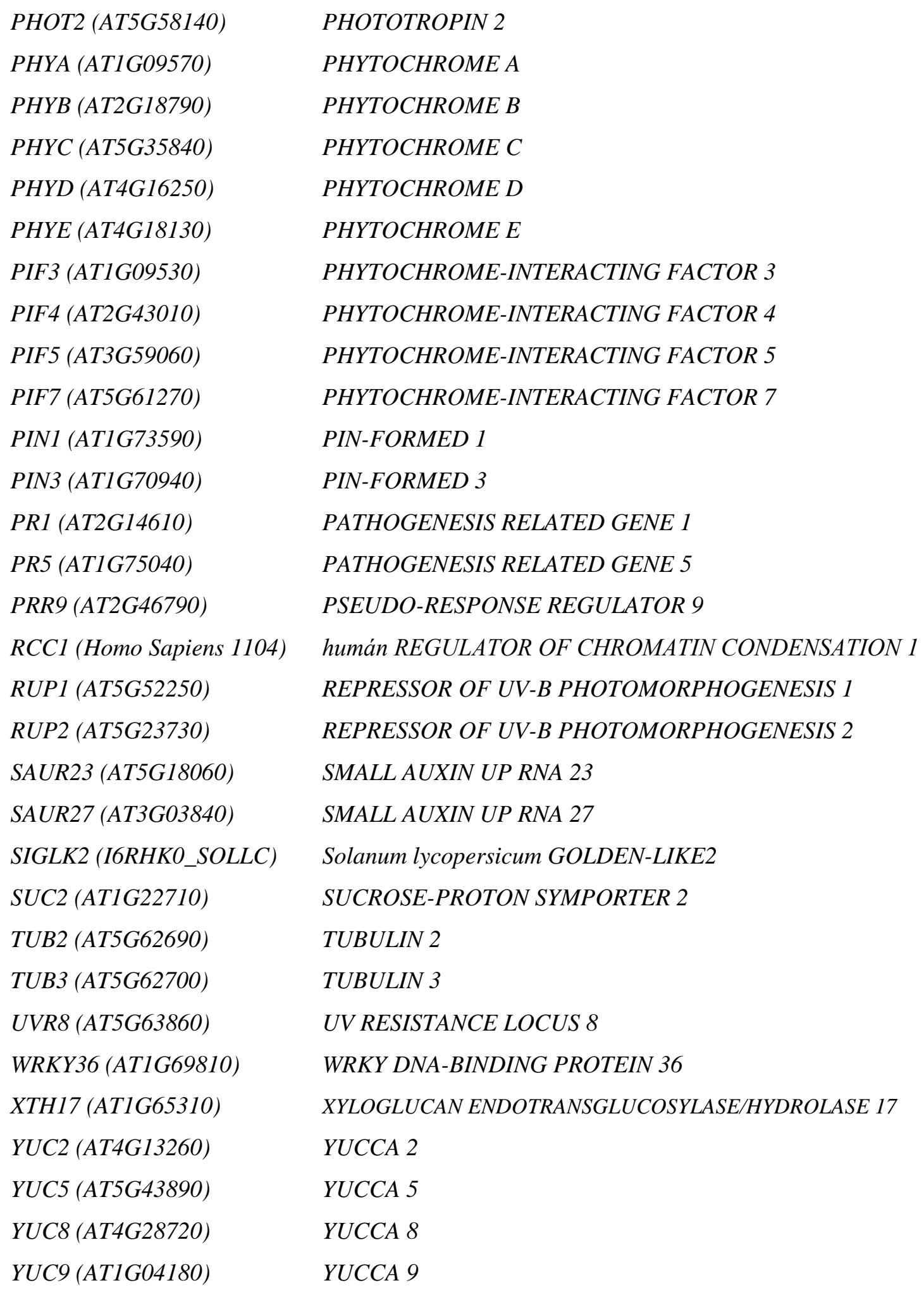




\section{BEVEZETÖ}

A szárazföldi növényeknek kiemelkedően fontos, hogy alkalmazkodni tudjanak az őket körülvevő, folyton változó környezethez. A kedvező hatásokat minél jobban ki kell használniuk annak érdekében, hogy fejlödésük, növekedésük optimális legyen. Emellett a kedvezőtlen, akár káros hatású körülmények ellen védekezniük kell, hiszen ezeket aktív helyváltoztató mozgási képesség hiányában képtelenek elkerülni. A növények számára az egyik legfontosabb környezeti tényező a Föld felszínét elérő napfény, pontosabban annak minősége és mennyisége. A fénykörülmények nyomon követése kiemelten fontos, mert a fény kettős szerepet játszik a növények életében: a fotoszintetikus folyamatok meghajtása révén energiához juttatja a növényeket, másrészről éppen az életfolyamatok optimalizálása érdekében, a növények a fényt jelként is érzékelik. A változó fénykörülmények nyomon követése érdekében a növények számos fényérzékelő fehérjét, fotoreceptort használnak, melyek összességében a napsugárzásból származó fény majdnem teljes spektrális tartományát képesek érzékelni. A receptorok segítségével a növények átfogó képet kapnak a megvilágítás intenzitásáról, hullámhossz-összetételéről, irányáról, időtartamáról, napi ritmusáról. Ezek az információk a növények minden fejlödési szakaszában segítséget adnak ahhoz, hogy fiziológiai folyamataikat az adott fényviszonyoknak megfelelően optimalizálják. A fotoreceptorok a növények élettani folyamatainak többségét befolyásolják, ilyenek például a csírázás, a csíranövények fejlödése, a fototropizmus, az árnyékkerülés, a színtestek mozgása, a gázcserenyílások szabályozása, valamint a nappalok hosszának érzékelése (Sullivan és Deng, 2003). A növények számára a fény fontossága a génkifejeződés szintjén is megnyilvánul, ugyanis a fehér fény a lúdfü (Arabidopsis thaliana) modellnövényben a genom körülbelül 10-30 \%-ának az expresszióját befolyásolja (Ma és mtsai., 2001). Mindezek alapján joggal vált az utóbbi idők népszerü kutatási területévé a fotoreceptorok jelátviteli folyamatainak vizsgálata, ezen belül is egyre intenzívebben kutatott terület a különböző szövetekben lejátszódó részfolyamatok felderítése. Bonyolult, egymással is összefüggő jelátviteli láncolatok biztosítják a gyors, precíz válaszreakciók létrejöttét a változó fénykörülményekre, amelyek részleteinek megismerése segít jobban megérteni a teljes fényjelátviteli hálózat müködését.

A napfény része az ultraibolya $(\mathrm{UV}=$ ultraviolet $)$ tartomány, amit három részre osztanak: a legrövidebb hullámhosszúságú tartomány az UV-C (100-280 nm), ezt követi az UV-B (280-315 nm), majd pedig az UV-A (315-400 nm). Az UV-B sugarak nagy része annak ellenére eléri a Föld felszínét, hogy jelentős részét a sztratoszférikus ózonréteg elnyeli. Az UV-C sugarak egyáltalán nem jutnak el a Föld felszínére, míg az UV-A tartományba eső sugarakat nem nyeli el az ózonréteg. Az UV-B sugárzás, dózistól függően, változatosan képes hatni a növényekre. Nagy energiatartalmának köszönhető károsító hatása miatt könnyen képes stresszválaszokat 
kiváltani, makromolekulákat roncsolni (Hollósy, 2002). Kisebb dózisban azonban az UV-B sugárzás számos jelátviteli folyamatot képes szabályozni akut károk okozása nélkül. Ezek a folyamatok leginkább növekedéssel kapcsolatos válaszok, valamint fénystressz elleni (akár megelőző célú) akklimációs, vagy hosszabb távon adaptációs folyamatok részei. Az UV-B sugárzás által, károkozástól függetlenül elindított jelátviteli folyamatokban kulcsszerepet játszik az UV RESISTANCE LOCUS 8 (UVR8) fehérje, amit 2011-ben UV-B specifikus fotoreceptorként azonosítottak (Rizzini és mtsai., 2011).

Az UVR8 fotoreceptorral kapcsolatban rövid idő alatt számos új információ született, ennek ellenére müködésével és az általa irányított jelátviteli rendszerrel kapcsolatban még mindig sok a megválaszolatlan kérdés. Az UVR8 megtalálható a felnőtt Arabidopsis minden szervében (Rizzini és mtsai., 2011), de szöveti szintủ eloszlásának és expressziós szintjének precíz vizsgálata nem történt meg mostanáig, ezért munkánkban ezek felderítésére kiemelt hangsúlyt fektettünk. Ezen túlmenően célul tủztük ki az UVR8 általi szabályozás alatt álló jelátviteli utak tér- és időbeli vizsgálatát is. A szöveti autonómiára vonatkozó vizsgálatokhoz egyre szélesebb körben alkalmaznak korábban jellemzett, különböző szövetekben müködő promótereket, melyek segítségével transzgenikus növényekben in vivo végezhetőek ilyen célú kísérletek. Munkánk során ilyen promótereket is alkalmazva azt vizsgáltuk meg, hogyan alakul az UV-B által vezérelt jelátviteli útvonalak összefonódása, vagy éppen szétválása. Mindezeket a vizsgálatokat különbözö szervekre, szövetekre vonatkoztatva is elvégeztük, hogy részletesebb képet kapjunk az UVR8 által vezérelt jelátviteli hálózatról. 


\section{IRODALMI ÁTTEKINTÉS}

\subsection{Fényérzékelő fehérjék a növényekben}

A fény olyan hullámhosszúságú tartományba eső elektromágneses sugárzás, amit az emberi szem érzékelni tud (390-750 nm) (1. ábra). Az ember számára az ultraibolya sugarak láthatatlanok, ezért definíció szerint erre a tartományra nem fényként, hanem sugárzásként hivatkozunk. Míg a Föld légköre kiszüri az UV-C sugarakat, addig az UV-B nagyobb része, valamint az UV-A sugarak teljes mértékben átjutnak a légkörön. A növények ezt a két tartományt is képesek érzékelni.

A fény kiemelten fontos környezeti tényező a növények számára, mivel a fotoszintézishez energiát biztosít, ugyanakkor a túl erős fény szabadgyökök felszabadítása révén a szerves makromolekulák károsodását okozhatja (Ksas és mtsai., 2015). Éppen ezért létfontosságú, hogy a növények alkalmazkodni tudjanak az állandóan változó fénykörülményekhez. Ennek érdekében számos fotoreceptoruk segítségével képet alkotnak a környezetük fénykörülményeiről, ennek segítségével optimalizálják a növekedésüket, fejlődésüket, szaporodásukat befolyásoló folyamatokat. A növényi fényérzékelő fehérjékről (fotoreceptorokról) általánosan elmondható, hogy kevés kivételtől eltekintve a következő tulajdonságok jellemzik őket: fény (és/vagy UV sugárzás) hatására fényelnyelő kromofórjuk által valamilyen visszafordítható változás történik a szerkezetükben, aminek következtében legalább egy jelátviteli lánc müködését képesek befolyásolni. A fotoreceptorok jelátviteli folyamatai általában a sejtmagban indulnak el (Ziegler és Möglich, 2015).

A növények számára legfontosabb információkkal a napfény vörös/távoli vörös, kék, illetve UV-B tartományba eső sugarai szolgálnak. Arabidopsisban a vörös és távoli vörös fényt érzékelő fotoreceptorok a fitokrómok (phyA-phyE) (Schäfer és Bowler, 2002; Bae és Choi, 2008), a kék és UV sugárzást érzékelők a fototropinok, kriptokrómok, továbbá a Zeitlupe (ZTL) receptorcsalád tagjai (Briggs, 2007). Az UV-B sugarak érzékeléséért leginkább az UVR8 nevü, nemrég felfedezett UV-B receptor a felelős (Rizzini és mtsai., 2011).

A vörös/távoli-vörös tartományban (600-750 nm) müködő fitokrómok hisztidin-kináz motívumot tartalmazó dimer fehérjék, melyek fényérzékenységéért a kovalensen kötött fitokromobilin kromofór oldallánc felelős. A fitokrómok fénykapcsolókként müködnek, a kapcsoló két állása, vagyis a biológiailag aktív és inaktív forma közti váltást (konformációs változás a molekula szerkezetében) a fitokrómokat érő fény minősége irányítja: a fitokrómok biológiailag inaktív formában vannak jelen a citoplazmában sötétben és távoli vörös fényben, ez a vörös fényt elnyelő forma a $\mathrm{P}_{\mathrm{r}}$ (abszorpciós maximuma: $\lambda_{\max }=660 \mathrm{~nm}$ ). A biológiailag aktív, távoli vörös fényt 
elnyelö forma a $\mathrm{P}_{\mathrm{fr}}$ (abszorpciós maximuma: $\lambda_{\max }=730 \mathrm{~nm}$ ), ami pedig a sejtmagba vándorolva, transzkripciós faktorokkal együttmüködve fejti ki hatásait (Nagy és Schafer, 2002; Kevei és mtsai., 2007). Arabidopsisban a fitokrómokat öt gén kódolja: PHYA, PHYB, PHYC, PHYD, PHYE. Az ötféle fehérje között szerkezetüket tekintve csak kicsi az eltérés, mégis más-más funkciókat látnak el (Li és mtsai., 2011). Az I-es csoportba tartozó phyA legfontosabb feladata a szkotomorfogenezisből (fejlődési program sötétben) a fotomorfogenezisbe (fejlődési program fényben) történő átlépés elindítása (Casal és mtsai, 2014). A II-es csoportba a többi fitokróm tartozik (phyB-E), ezek a phyA-hoz képest sokkal stabilabbak fényben. Többek között a csíranövények növekedésében, a zöldülésben, a szár megnyúlásában, a virágzás szabályozásában és az árnyékkerülési folyamatok irányításában vesznek részt (Li és mtsai., 2011).

A kék (390-500 nm) és az UV-A (320-390 nm) tartomány legfontosabb növényi receptorai a kriptokrómok (CRY1, CRY2) és a fototropinok (PHOT1, PHOT2). A kriptokrómok elsősorban az UV-A, vagy a kék fény által kiváltott zöldülési folyamatokat, fototropikus, vagyis a fény irányától függő növekedési válaszokat, virágzást irányítanak (Ahmad és mtsai., 1998). A szerkezeti hasonlóság ellenére a kriptokrómokra is jellemző, hogy eltérően müködnek bizonyos folyamatok szabályozásában: míg a hipokotil megnyúlás gátlásában mindkét kriptokróm részt vesz (Ahmad és mtsai., 1998; Ahmad és mtsai., 2002), addig a virágzás idejét a CRY2 képes befolyásolni, a CRY1 viszont egyáltalán nem (Guo és mtsai., 1998). N-terminális végükön fotoliázszerü doménnel rendelkeznek, ehhez a régióhoz köt a FAD (flavin adenine dinucleotide) és az MTHF (flavin plus either methenyltetrahydrofolate) kromofór. C-terminálisukon egy szerin/treonin kináz jellegü elem található (Lin és Shalitin, 2003). Sötétben zárt konformációban vannak, majd fény hatására konformációs változáson esnek át, aminek következtében saját magukat foszforilálják (Bouly és mtsai., 2003; Shalitin, és mtsai., 2003; Liu és mtsai., 2017). Ennek hatására szabaddá válik az N-terminális végükön lévő elem, ami azért felelős, hogy kölcsönhatásba lépjen a receptorok által szabályozott jelátviteli molekulákkal. Arabidopsisban a CRY2 fehérje fényben gyorsan lebomlik, ezért föleg erős fényben a CRY1 a domináns kriptokróm (Yu és mtsai., 2007).

A PHOT1 és a PHOT2 fototropikus válaszok kiváltásában, a kloroplasztiszok mozgásának szabályozásában, valamint a gázcserenyílások nyitásában, vagyis összességében a fotoszintézis optimalizálásában és a túl erős fény által okozott károk elkerülésében játszanak szerepet (Huala és mtsai., 1997; Sakai és mtsai., 2001; Briggs és Christie, 2002). Friss kutatási eredmények arra utalnak, hogy a fototropinok képesek az UV-B sugárzás érzékelésére is (Vandenbussche és mtsai., 2014), erről bővebben az eredmények bemutatásánál fogok írni. A fototropinok, annak ellenére, hogy nem rendelkeznek membránkötő doménnel, a plazmamembránhoz asszociálva müködnek (Harada és mtsai., 2003). A fototropinok C-terminálisán egy klasszikus szerin/treonin kináz elem található (Hanks és Hunter, 1995), az N-terminálisukon pedig két, a kromofórokat nem kovalensen kötő LOV (Light/Oxygen/Voltage) motívum helyezkedik el (Huala és mtsai., 1997; Sakai és mtsai., 2001). 
FMN (flavin mononucleotide) kromofórjuknak köszönhetően kék/UV-A sugárzás hatására bekövetkező konformációs változás a fototropinok autofoszforilációját eredményezi, ami a jelátviteli láncuk első lépései közé tartozik (Sakai és mtsai., 2001).

Az UV-B tartomány érzékeléséért (a fototropinokon kívül) az UVR8 fehérje felelős. Szerkezetét, müködését részletesen bemutatom a 2.3-as fejezettől kezdve.

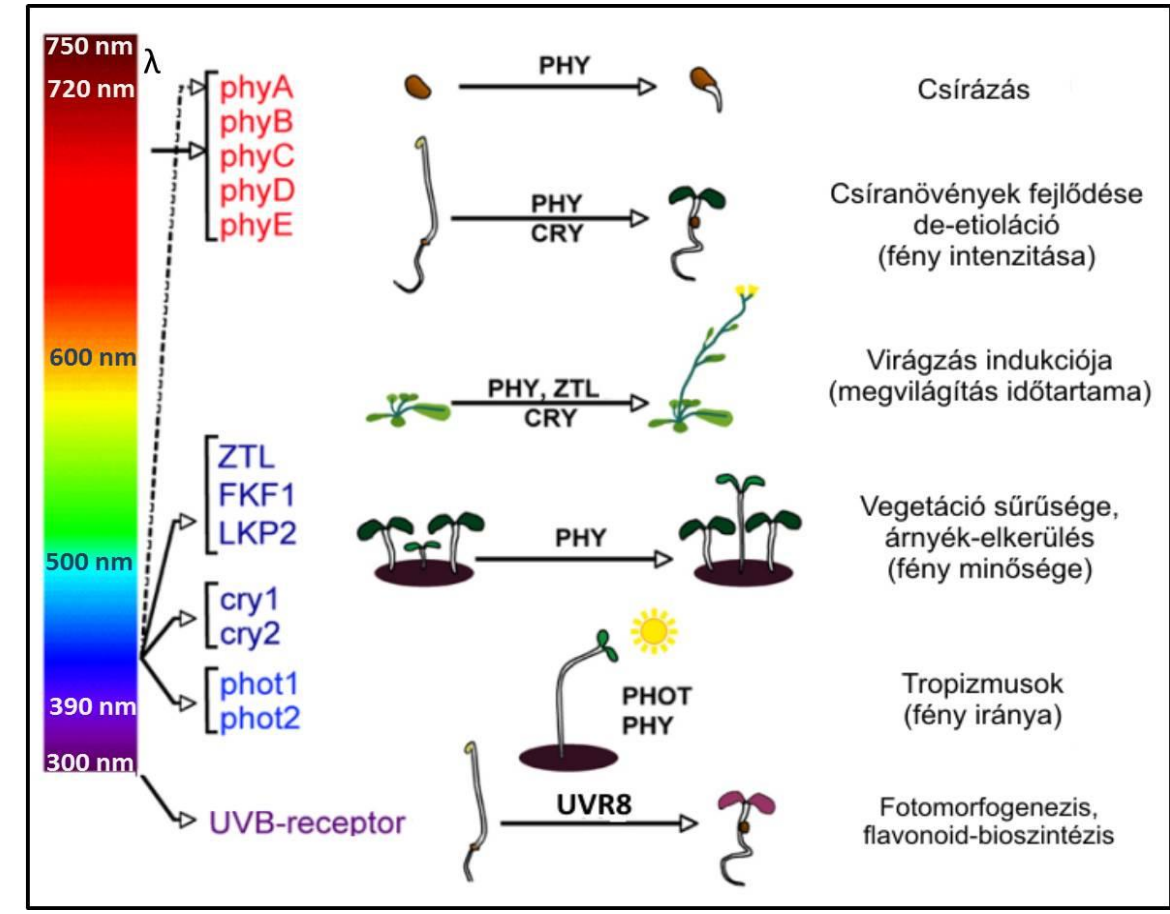

1. ábra: A napfény spektruma és növényi fotoreceptorok

(Fankhauser alapján, www.unil.ch)

A fény olyan elektromágneses sugárzás, amit az emberi szem érzékel. A növények számára a látható fényen kívül az UV-B és UV-A tartomány észlelése is fontos. Az UV-B sugárzástól a távoli vörös fényig a növények számos fotoreceptor segítségével majdnem a teljes fényspektrumot képesek érzékelni. Ez a képesség nélkülözhetetlen a folyton változó fénykörülményekhez történő alkalmazkodáshoz. Az ábrán néhány olyan folyamat is olvasható, amelyeket az adott fotoreceptorok szabályoznak.

\subsection{UV-B sugárzás: stresszor, vagy környezeti jel?}

\subsubsection{UV-B sugárzás, mint stressz faktor}

Az abiotikus tényezők, mint amilyen a fény is, minden tulajdonságukra nézve egy-egy tartományban optimálisak az élölények számára. Ha a környezeti faktorok közül az egyik hatása nem optimális, az a körülmény stresszorként hat a növényre (Lichtenthaler, 1998). A kedvezőtlen körülményekhez a növények képesek alkalmazkodni, hosszú távon genetikai alapokon történő morfológiai változásokkal (adaptáció: öröklődő alkalmazkodóképesség bizonyos környezeti körülményekhez), vagy a gyors változásokkal szemben védekező folyamatok elindításával 
(akklimáció: alkalmazkodás egy bizonyos környezeti tényező megváltozott hatásához) (Lichtenthaler, 1998). A továbbiakban az UV-B sugárzás, mint környezeti tényezö általános hatásait mutatom be.

A Földet körülvevő ózonréteg szürőként óvja az élőlényeket a túl erős UV-B sugárzástól, azonban a Napból származó UV-B sugarak egy része így is eléri a Föld felszínét. Rövid hullámhossza (280-315 nm) miatt az UV-B sugárzás energiatartalma nagyon magas, ezért könnyen károsítani tudja a DNS-t, a fehérjéket, a lipideket (Hollósy, 2002). A káros reaktív oxigénszármazékok (Reactive Oxygen Species $=$ ROS) keletkezése együtt jár az aerob légzéssel és a növényi fotoszintézis folyamatokkal, amik pedig függnek a fénykörülményektöl. A különbözö ROS fajták felhalmozódása általános következménye a legtöbb fajta stressznek, így a túlzott mennyiségü fény miatti stressznek is (Mittler, 2002; Yanykin és mtsai., 2010; Krieger-Liszkay és mtsai., 2011). A ROS-ok prooxidánsokként viselkednek, vagyis túl nagy mennyiségben oxidatív stresszt okoznak az élő szervezetekben (Halliwell 2007). Az oxidatív stresszt kiváltó ROS fajták a triplet oxigén $\left({ }^{3} \mathrm{O}_{2}\right)$, a szinglet oxigén $\left({ }^{1} \mathrm{O}_{2}\right)$, a szuperoxidgyök-anion $\left(\mathrm{O}_{2}{ }^{\circ}\right)$, a hidrogén-peroxid $\left(\mathrm{H}_{2} \mathrm{O}_{2}\right)$ és hidroxilgyök ( $\left.\mathrm{OH}\right)$ (Navari-Izzo és mtsai., 1999; Ivanov és mtsai., 2007; Yanykin és mtsai., 2010; Krieger-Liszkay és mtsai., 2011). A természetes napsugárzásban jelen lévő UV-B önmagában általában nem okoz stresszt, azonban más környezeti tényezők megváltozásával együtt, vagy laboratóriumi körülmények között nagyobb dózisban okozhatja stresszválaszok megjelenését (Hideg és mtsai., 2013). Az UV-B sugárzás több módon is lassítja a fotoszintézist, aminek egyenes következménye a közben természetes úton keletkező ROS-ok termelődésének fokozódása, mivel az elektrontranszport gátlása elősegíti a ROS képződést: az UV-B sugárzásra legérzékenyebb sejtalkotó a fotoszintetikus apparátus, károsodása gátolja a fotoszintézist, amit a sztómazáródás miatti csökkent gázcsere tovább lassít (Nogues és mtsai., 1999; Hideg és Strid, 2016). Az evolúció során a növények számos stratégiát fejlesztettek ki az UV-B elleni védekezésre, az egyik legelterjedtebb a növény felszínhez közeli szöveteiben megfigyelhető UV-B szürő flavonoidok felhalmozása (Jenkins, 2009). Ha a védekező válaszok nem elégségesek a károk elkerüléséhez, az aktiválódó javító mechanizmusok igyekeznek enyhíteni a keletkezett károsodást. A felhalmozódó ROS semlegesítést hatékony antioxidáns rendszerek végzik (Bornmann 1997), a DNS-ben történt károkat pedig fényindukált fotoliáz enzimek javítják (Britt 2004).

Nagy intenzitású UV-B sugárzás hatására tehát általában megemelkedik a ROS szint, felborul a redox homeosztázis, kialakul az oxidatív stressz (Mittler, 2002). Az alkalmazkodás sikeressége leginkább azon múlik, hogy a növényekben fennálló egyensúly a ROS szint és az ezeket semlegesíteni képes antioxidáns rendszerek müködése között fennmarad-e. Minden vegyület antioxidánsnak tekinthetö, ami képes egy bizonyos szubsztrát oxidációját késleltetni, vagy gátolni (Halliwell 2015). Nem enzimatikus antioxidánsok az aszkorbát (együttmüködve a glutationnal), a karotinoidok, a tokoferolok, a $\mathrm{B}_{6}$-vitamin család tagjai, valamint a fenolos vegyületek közé tartozó flavonoidok is. Az antioxidáns rendszerek fontosságát alátámasztja, hogy a ROS-ok elleni 
védekezésben számos enzim is részt vesz: az aszkorbát peroxidáz, a kataláz, a hármas típusú peroxidázok osztályába tartozó enzimek, valamint a szuperoxid dizmutáz (Mackerness és mtsai., 2001; Shigeto és Tsutsumi, 2016).

Annak ellenére, hogy a ROS-ok nagyon reaktívak, kis koncentrációban jelzőmolekulákként is viselkednek, ezáltal részt vesznek az oxidatív stressz elleni védekezés serkentésében (Foyer és Noctor, 2005; Choudhury és mtsai., 2013). Erre jó példa, hogy a ${ }^{1} \mathrm{O}_{2}$ képes fokozni Chlamydomonasban a GLUTATHIONE-PEROXIDASE HOMOLOG (GPXH) gén transzkripcióját, aminek a fotooxidatív károsodások kivédésében van fontos szerepe (Fischer és mtsai., 2007). Mivel bizonyos ROS molekulák jelként is müködnek, a mennyiségüket befolyásoló antioxidáns rendszerek közvetett módon befolyásolják a ROS-ok által kiváltott folyamatokat, de ezen túlmenően bizonyos antioxidánsok közvetlenül is képesek jelátviteli utakat szabályozni. A peroxidázok például részt vesznek az auxin növekedési hormon metabolizmusban, sőt, auxinoxidázként gátolhatják a hipokotil megnyúlását UV-B sugárzás hatására, ami az egyik legismertebb, károsodás nélkül is megjelenő UV-B-válasz (Jansen és mtsai., 2001; Cosio és Dunand, 2009). A nem enzimatikus antioxidánsok közül a flavonoidok rendelkeznek auxin müködést befolyásoló tulajdonsággal: túl azon, hogy a flavonoidok felhalmozódásuk révén szürik az UV-B sugárzást, valamint többrétü antioxidáns hatásuk is van (Pietta, 2000; Jansen és mtsai., 2001), jelként müködve gátolják az auxin növekedési hormon hajtáscsúcsból a gyökér irányába történő (bazipetális) transzportját is (Brown és mtsai., 2001; Jansen és mtsai., 2001; Peer és Murphy, 2007). Ebből az következik, hogy a flavonoidok felhalmozódása is hozzájárul a hipokotil növekedés gátlásához.

\subsubsection{UV-B sugárzás, mint jel}

Már az 1970-es években kimutatták, hogy az UV-B sugárzás képes befolyásolni a növények növekedését, kinézetét, valamint biokémiai változásokat is okozhat (Klein 1978). Éppen ezért évtizedek óta foglalkoztak az UV-B sugárzás jelként történő érzékelésével, ugyanis felfedezték, hogy az alacsony intenzitású UV-B sugárzás olyan fotomorfogenikus válaszokat indított el a növényekben, melyek nem voltak DNS károsodással magyarázhatók (Wellmann, 1976). Nagy intenzitású UV-B hatására is lejátszódnak jelátviteli folyamatok, bár ezek inkább stresszhez köthetőek, így ezeket nem kapcsoljuk az UV-B jelátvitelhez.

A kérdés, mely szerint az UV-B sugárzás stresszor, vagy jel, mindezek alapján könnyen megválaszolható: mindkettő. Az UV-B sugárzás növényekre gyakorolt hatása nagyban függ az intenzitásától és a növényekre ható egyéb körülményektől, de általánosságban elmondható, hogy a növényt nem károsító intenzitású UV-B jelként, míg a károsodást okozó intenzitású UV-B sugárzás inkább stresszorként fejti ki hatását. A későbbiekben a jelként funkcionáló, alacsony intenzitású 
UV-B sugárzás által elindított, főleg az UVR8-hoz köthető jelátviteli utakat és ezek hatásait mutatom be részletesen.

\subsection{UVR8: a növényi UV-B fotoreceptor}

\subsubsection{Az UVR8 fotoreceptor felfedezése}

Már jóval az UVR8 felfedezése elött sejteni lehetett, hogy a növények rendelkeznek egy UV-B specifikus fotoreceptorral. Klebenstein és munkatársai (2002) azonosítottak egy Arabidopsis mutánst, amit uvr8-nak (UV RESISTANCE LOCUS 8) neveztek el, mert az általa hordozott mutáció miatt a növény több UV-B-válaszreakcióban túlérzékenységet mutatott. Később kiderült, hogy az UVR8 fehérje részt vesz az UV-B által indukált jelátviteli folyamatokban. Az uvr8 mutánsban az UV-B sugárzás nem tudta az ELONGATED HYPOCOTYL 5 (HY5) transzkripciós faktor génjének kifejeződését megemelni, ezzel szemben az indukció megfigyelhető maradt látható fény, alacsony hőmérséklet és szacharóz hatására is (Brown és mtsai., 2005). Mindezek az eredmények UV-B specifikus müködésre utalnak, ám az UVR8-ról ekkor még nem tudták, hogy fotoreceptorként müködik. Favory és munkatársai 2009-ben elvégeztek egy transzkriptóma analízist, és azt találták, hogy az alkalmazott gyenge UV-B sugárzás vad típusú növényben egy óra alatt 377 gén aktivitását fokozta, míg 102 génét csökkentette. Az indukált gének 98,6\%-a az UVR8-tól, ráadásul 99,5\%-uk a CONSTITUTIVE PHOTOMORPHOGENIC 1 (COP1) E3 ubiquitin ligáztól is függött. Az UV-B sugárzás által represszált 102 gént kivétel nélkül szabályozza az UVR8 és a COP1 is. A megváltozott kifejeződésű gének többsége az UV-B elleni védekezésben játszik szerepet. A COP1 a fény irányította jelátviteli utak egyik kulcsszereplöje, a SUPPRESSOR OF PHYA-105 (SPA1-4) fehérjékkel komplexben (COP1 homodimer és két SPA fehérje együtt) végzi bizonyos fehérjék ubiquitinációját, vagyis lebontásra jelöli ki azokat (Laubinger és mtsai., 2004; Zhu és mtsai., 2008; Podolec és Ulm, 2018). Favory és munkatársai (2009) a két kulcsfehérje sejtmagi elhelyezkedését is megvizsgálta különböző fluoreszcens fehérjéket fúzionáltatva hozzájuk. Az UVR8 dimerek UV-B sugárzás hiányában a citoplazmában is megtalálhatóak, a (GFP-vel megjelölt) UVR8 molekulák egyenletes sejtmagi eloszlást mutattak, míg UV-B sugárzásban a COP1-hez hasonlóan sejtmagi aggregátumokba csoportosultak (Kaiserli és Jenkins, 2007; Yin 2016), ez viszont még nem bizonyítja a két fehérje közötti kölcsönhatást. Nem sokkal később azonban kimutatták, hogy az UVR8 és a COP1 között közvetlen kölcsönhatás jön létre UV-B-től függő módon (Favory és mtsai., 2009). Az UVR8 N-terminálisán lévő, meghatározott 23 aminosav (397-423) önmagában elég és szükséges is a COP1 WD40 motívumán keresztüli kötődéséhez. A WD40 az eukarioták körében az egyik legelterjedtebb interakciós motívum, akár fehérje-fehérje, akár fehérje-DNS kölcsönhatásokban 
(Xu és Min, 2011). A COP1-gyel kölcsönható SPA fehérjék szintén rendelkeznek WD40 doménnel, ezek a fehérjék is kölcsönható partnerei az UVR8-nak, és fontos szerepet játszhatnak más kölcsönható partnerek kötődésének befolyásolásában, azok komplexről történő leszorítása által (Huang és mtsai., 2013; Chen és mtsai., 2016; Podolec és Ulm, 2018). Ahogy korábban említettem, az UVR8 UV-B sugárzás által kiváltott sejtmagi felhalmozódásához a molekula N-terminálisán lévő meghatározott 23 aminosav szükséges (Cloix és mtsai., 2012). Mivel ez a szakasz nem tartalmaz sejtmagi lokalizációs jelet (Nuclear Localisation Signal = NLS), nagy valószínűséggel az UVR8 sejtmagi felhalmozódása egy NLS tartalmú fehérjétől függ, ami ráadásul ehhez az N-terminális szakaszhoz képes kötődni. Hasonló folyamat játszódik le a phyA esetében is, aminek a sejtmagi importjában a FAR-RED ELONGATED HYPOCOTYL (FHY1) és a FHY1 LIKE (FHL) fehérjék játszanak szerepet (Hiltbrunner és mtsai., 2005; Hiltbrunner és mtsai., 2006).

Az UVR8-ról tudni lehetett, hogy részt vesz UV-B által kiváltott jelátviteli folyamatokban. Rizzini és munkatársai 2011-ben bizonyították, hogy az UVR8 az UV-B indukált jelátvitelben nem csak egyszerủen részt vesz, hanem fotoreceptorként múködik. Bemutatták, hogy UV-B sugárzás hatására az alapesetben dimer formában előforduló UVR8 monomerekké esik szét, tehát változás történik a szerkezetében. Ez az egyik általános jellemzője a fotoreceptoroknak. Ráadásul élesztő két-hibrid kísérletekből az is kiderült, hogy az UVR8 és COP1 közti kölcsönhatás UV-B specificitását az UVR8 fehérje biztosítja, ami egyértelmúvé tette, hogy valóban az UVR8 felelős a válaszok UV-B-függéséért (Rizzini és mtsai., 2011). Mindezek alapján az UVR8 fehérje valóban alkalmas arra, hogy fotoreceptorként müködjön, mivel UV-B sugárzástól függően, a kialakuló kölcsönhatás által befolyásolja egy fényjelátviteli komponens, a COP1 müködését. A jelátvitel további lépéseit és résztvevőit a 2.4-es fejezetben mutatom be részletesen.

\subsubsection{Az UVR8 szerkezete}

Az UVR8 gén egy hétlapátos $\beta$-propeller fehérjét kódol (2. ábra), ami felépítésében hasonlít az emberi REGULATOR OF CHROMATIN CONDENSATION 1 (RCC1) fehérjéhez (Brown és mtsai., 2005). Korábban említettem, hogy az UVR8 alapállapotában inaktív homodimerekként van jelen a növényekben, ezek UV-B sugárzás hatására biológiailag aktív monomerekké esnek szét. Az a felület, ahol egymással kölcsönhatásba lépnek a monomerek, sok aromás és töltéssel rendelkező aminosavat tartalmaz, a felületek között kialakuló sóhidak tartják össze a monomereket, ezek szakadnak fel UV-B általi gerjesztés hatására. Az így kialakult aktív monomerek fejtik ki élettani hatásukat a sejtmagban (Christie és mtsai., 2012).

Az UVR8 nem rendelkezik a többi növényi fotoreceptoréra jellemző klasszikus értelembe vett prosztetikus kromofórral. A kromofórok fényelnyelő feladatát az UVR8 molekulán belül meghatározott elhelyezkedésü triptofán aminosavak látják el (2. ábra C-D), ugyanis a triptofán aminosav jellegzetes elnyelési sávval rendelkezik az UV-B tartományban (O'Hara és Jenkins, 
2012). A 233., 285. és a 337. triptofán kiemelt fontosságú, ugyanis bármelyiket alaninra cserélve az UVR8 nem müködik fotoreceptorként (mivel az alanin nem képes jól elnyelni az UV-B sugarakat). Ha a 285. triptofánt fenilalaninra cseréljük, az UVR8 dimerek nem képesek monomerizálódni sem (Christie és mtsai., 2012; Heijde és mtsai., 2013). Ez kifejezetten érdekes, ugyanis a dimerizációra való képesség megmaradása arra enged következtetni, hogy az aminosav cseréje nem okozza a fehérje szerkezetének drasztikus megváltozását, a molekula mégis funkcióképtelenné válik. A 285. triptofán kulcsszerepét továbbá az is alátámasztja, hogy azt alaninra cserélve az új UVR8 variáns folyamatosan monomer állapotban van és kötődik a COP1-hez (Rizzini és mtsai., 2011). Továbbá azt is kimutatták, hogy ugyanezt a mutáns UVR8-at termelö növények folyamatos UV-B-választ adtak fényben és sötétben egyaránt, tehát a 285. triptofánt alaninra cserélve egy folyamatosan aktív UVR8 variáns állt elő, ami tovább erősítette a triptofánok fontos szerepére vonatkozó eredményeket (Heijde és mtsai., 2013). Mindezek a megállapítások a triptofán aminosavak kromofór szerepét bizonyítják.
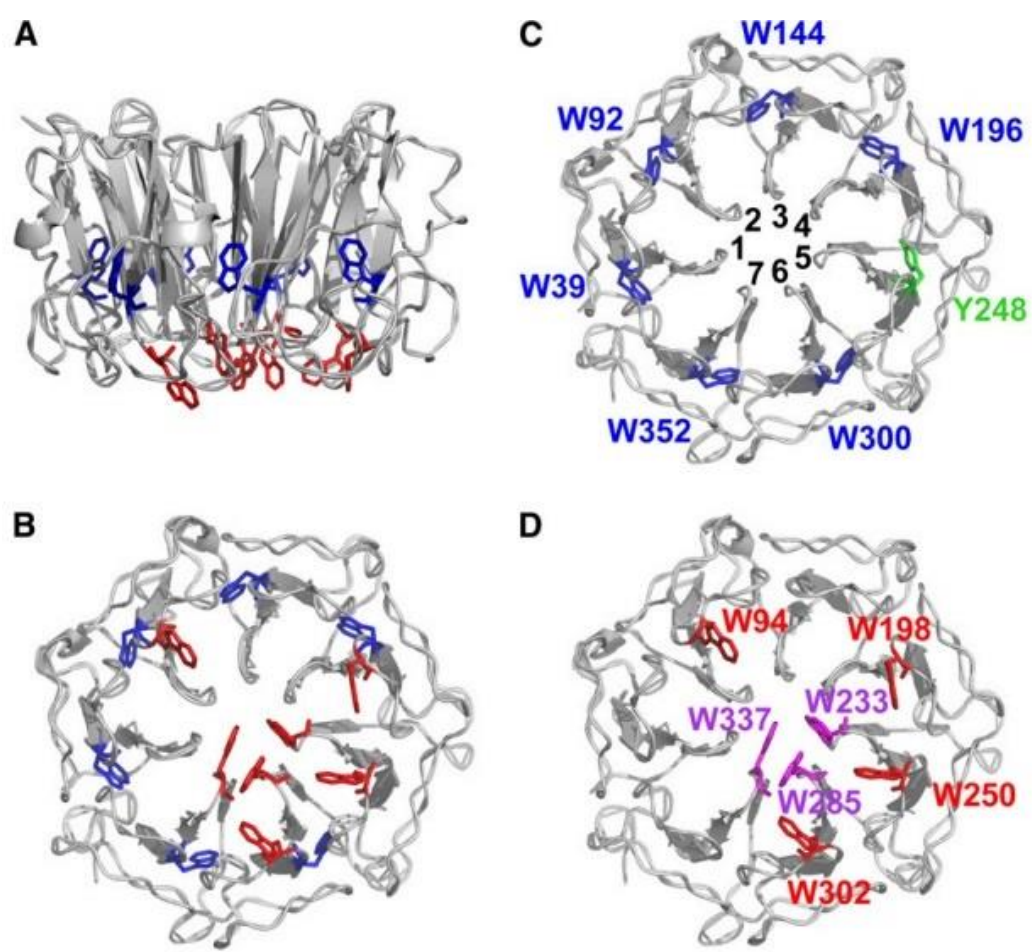

\section{2. ábra: Az UVR8 fotoreceptor szerkezete (O'Hara és Jenkins, 2012)}

A) A molekula síkjával párhuzamos nézet. Hat triptofánt találhatunk a központban (kékkel jelölve), hetet a kölcsönható felületen (pirossal jelölve) és egyet a C-terminális régióban (nincs jelölve).

B) Interakciós felület felőli nézet, a triptofánok jelölése megegyezik az A) panel jelöléseivel.

C) A központi triptofánok elhelyezkedése (kékkel és zölddel jelölve), mindegyik egy-egy lapáthoz tartozik (lapátok számozva). Az Y248 zárja a triptofán-gyürüt (zölddel jelölve).

D) A kölcsönható felületben található triptofánok. A dimerizációban (és így a fényérzékelésben) legfontosabb szerepet játszó, vagyis a triádba tartozó triptofánok rózsaszínnel, a többi pirossal van jelölve. 


\subsection{Az UVR8 által irányított jelátviteli utak}

\subsubsection{Az UVR8 jelátvitel első lépései}

Az UV-B-től függő UVR8 jelátviteli folyamatok legelső lépése az UVR8 dimerek szétesése biológiailag aktív monomerekké. Az UVR8 megtalálható a citoplazmában és a sejtmagban is, UV-B sugárzás hatására azonban mennyisége számottevően megemelkedik a sejtmagban (Kaiserli és Jenkins, 2007). Ezt a fényjelátviteli folyamatokban fontos szerepet játszó COP1 fehérje esetében is megfigyelték (Oravecz és mtsai., 2006), továbbá az is kiderült, hogy ez a két fehérje sejtmagi testecskékben kölcsönhatásba kerül egymással (Favory és mtsai., 2009). A legújabb eredmények alapján ráadásul a COP1 nélkülözhetetlen már az UVR8 sejtmagba jutásához is: egy glükokortikoid-receptor (GR) alapú rendszerrel kimutatták, hogy ha a GR-COP1 kimérafehérje nem tud bejutni a sejtmagba, elmarad az UV-B által kiváltott UVR8 sejtmagi import (Yin és mtsai., 2016). Ezt az is alátámasztja, hogy cop1 mutánsokban szintén elmarad az UVR8 sejtmagi akkumuláció (Yin és mtsai., 2016). Mindezek alapján a COP1 kettős szerepet játszik az UVR8 jelátvitelben, egyrészt az UVR8 sejtmagi importját segíti UV-B hatására, másrészt hat a jelátvitelre (utóbbiról később részletesen írok). A génexpressziós változások elindításához azonban nem elég önmagában az UVR8 sejtmagi felhalmozódása, UV-B sugárzás hiányában akkor sem indulnak el az UVR8-függő válaszok, ha a receptor nagy mennyiségben megtalálható a sejtmagban (Kaiserli és Jenkins, 2007; Jenkins, 2009). Az UV-B sugárzás szükséges a monomerré alakuláshoz és ahhoz, hogy az UVR8 C-terminálisa megváltoztassa a konformációját, aminek következtében a COP1 képes lesz az UVR8-hoz kötődni (Rizzini és mtsai., 2011). Az a tény, hogy a COP1 segíti az UVR8 sejtmagi felhalmozódását, arra utal, hogy az UVR8 fehérje nem a sejtmagban lép kölcsönhatásba a COP1-gyel, hanem az UVR8 monomerizálódása és kölcsönhatása a COP1-gyel már a citoplazmában létrejön. Ezt támasztja alá, hogy csak a monomer UVR8-hoz képes kapcsolódni a COP1, így a dimerek sejtmagba juttatásához valószínüleg nem tudna hozzájárulni (Rizzini és mtsai., 2011). Érdekes jelenség, hogy a GFP-UVR8 egy alacsonyabb, de kimutatható szinten jelen van a sejtmagban UV-B sugárzás hiányában is (Kaiserli és Jenkins, 2007; Yin és mtsai., 2016). Arra, hogy az UVR8 hogyan jut be a sejtmagba UV-B sugárzás hiányában, egyelőre nincs magyarázat. Annyit tudunk, hogy ezt a folyamatot biztosan nem a COP1 segíti elő: Yin és munkatársai (2016) kimutatták, hogy a COP1-UVR8 kölcsönhatáshoz szükséges N-terminális domént nélkülöző, GFP-kapcsolt UVR8 mutáns fehérje ugyanúgy jelen van a sejtmagban, mint a GFP-UVR8 fehérje, UV-B sugárzástól függetlenül is. Ez a deléció csupán az UVR8 UV-B által kiváltott további sejtmagi felhalmozódást gátolta (Yin és mtsai., 2016).

Az UVR8 és a COP1 fehérjék UV-B sugárzástól függő összekapcsolódása csak a jelátviteli lánc egyik első lépése. Ebből a kezdő lépésből következik, hogy a további hatások a 
COP1 múködésével szoros kapcsolatban állnak. A COP1 sötétben 26S proteaszóma általi lebontásra jelöl ki fehérjéket, többek között a kulcsfontosságú, fotomorfogenezist serkentő ELONGATED HYPOCOTYL 5 (HY5) bázikus leucin cipzár motívumot (basic Leucine-Zipper = bZIP) tartalmazó transzkripciós faktort, míg érdekes módon az UVR8 stabilitására nincs hatással (Osterlund és mtsai., 2000; Lau és Deng, 2012; Podolec és Ulm, 2018). Mindezekböl következtetésül levonhatjuk, hogy mivel az UV-B sugárzás hatására aktív UVR8 monomer kapcsolódik a HY5-ot gátló COP1-hez és ez által a COP1 aktivitása csökken, a HY5 fotomorfogenezist serkentő funkciói jobban érvényesülhetnek (Favory és mtsai., 2009; Rizzini és mtsai., 2011; Huang és mtsai., 2013; Podolec és Ulm, 2018). A COP1-SPA komplex müködését többek között a fitokrómok és a kriptokrómok, bár eltérő módon, de szintén gátolják, így ez a jelenség nem egyedülálló a fotoreceptorok körében (Podolec és Ulm, 2018). A COP1 és a HY5 viszonya azonban nem egy egyszerú gátláson alapul, ugyanis érdekes módon a COP1 a fehérjeszintű gátló hatása ellenére szükséges a HY5 gén indukciójához, ugyanis cop1 mutáns növényekben a HY5 gén expressziója lecsökken (Huang és mtsai., 2012). Ráadásul a COP1 által szabályozott folyamatok közel felére a HY5 is hatással van, ami bizonyos fokú együttmüködésre utal (Oravecz és mtsai., 2006). Az eddigi eredmények alapján felállított modellben a COP1 HY5-ot gátló hatását tekintjük kifejezettebbnek: a COP1 UVR8 általi inaktiválását követően a megemelkedett HY5 fehérjeszint hatására erősödnek a fotomorfogenikus válaszok, amiket tehát az UVR8 közremüködésével az UV-B sugárzás képes kiváltani. A két fehérje összetett viszonyára utal az is, hogy a HY5 pozitív visszacsatolásokban is részt vesz, indukálja a COP1 és a saját génjének átíródását is (Binkert és mtsai., 2014; Huang és mtsai., 2012).

A HY5 fehérjének van egy nagyon hasonló működésü homológja, a HY5 HOMOLOG (HYH). A HY5 és a HYH funkciói jórészt redundánsak, de a főbb szerepet a HY5 transzkripciós faktor játssza az UVR8 irányított jelátviteli folyamatokban (Brown és Jenkins, 2008). Ezt támasztják alá a hy5 és hyh mutánsokon végzett fenotípus kísérletek is: a hy5 növények, az uvr8 mutánshoz hasonlóan, túlérzékenyek az UV-B sugárzásra, a hyh növények viszont sokkal jobban tolerálják azt (Brown és mtsai., 2005; Oravecz és mtsai., 2006; Brown és Jenkins, 2008;). Az UV-B sugárzás UVR8-függő módon emeli mindkét transzkripciós faktor expresszióját, ráadásul HY5 hiányában az UVR8 indukált transzkriptóma sem teljes (Brown és mtsai., 2005; Favory és mtsai., 2009; Oravecz és mtsai., 2006). Tehát mivel a HY5 egy fotomorfogenezist serkentő transzkripciós faktor, ennél fogva a HY5 részvétele az UVR8 jelátvitelben megteremti a molekuláris kapcsolatot az UVR8 és a fotomorfogenikus válaszok között.

Az UVR8 szabályozás alatt álló HY5 nem csak fotomorfogenikus válaszokhoz kapcsolható gének indukciójáért felelős. Az EARLY LIGHT INDUCED PROTEIN 2 (ELIP2) fehérje a tilakoid membránok fotoprotekciójában vesz részt azáltal, hogy klorofill szintézis útvonalban szereplő enzimeket gátol, ezzel megelőzve az esetlegesen túlzott mértékü szabad klorofill előállítását, aminek megemelkedett ROS felszabadulás lenne a következménye (Hutin és mtsai., 2003). 
A PRODUCTION OF FLAVONOL GLYCOSIDES (PFG) családba tartozó MYB DOMAIN PROTEIN 12 (MYB12) transzkripciós faktor pedig a flavonol bioszintézisben játszik szerepet (Stracke és mtsai., 2010). Az előzőekhez hasonlóan a CHALCONE SYNTHASE (CHS) gén (az UV-B szűrő flavonoidok bioszintézisének kulcsenzimét kódolja) aktivitását szintén fokozza a HY5 (Jenkins és mtsai, 2001; Fehér és mtsai., 2011). Léteznek olyan gének is, melyek átíródását ugyan serkenti az UVR8, de ehhez nincs szükség sem a HY5, sem a HYH közremüködésére. Ilyenek például a CIRCADIAN CLOCK ASSOCIATED 1 (CCAl) és a PSEUDO-RESPONSE REGULATOR 9 (PRR9) (Fehér és mtsai., 2011).

A legtöbb jelátviteli folyamatban a pozitív szabályozó elemeket valamilyen negatív visszacsatolás féken tartja. Az UVR8 esetében ezt a feladatot a REPRESSOR OF UV-B PHOTOMORPHOGENESIS 1 (RUP1) és RUP2, WD40 elemet tartalmazó fehérjék végzik (Gruber és mtsai., 2010; Vanhaelewyn és mtsai., 2016). Az UVR8 által elindított jelátviteli folyamatok egyik kulcslépése az UVR8 és a COP1 között létrejövő kapcsolat, amiben szintén fontos szerepet játszanak a fehérjékben található WD40 motívumok, amikhez a RUP fehérjék más interakciós partnerekkel versengve kötődhetnek. Ilyen versengés és leszorítás történik az UVR8 esetében is: azáltal, hogy a RUP fehérjék az UVR8-hoz kötve gátolják a COP1 kölcsönhatását, az egész jelátviteli folyamatot gátolni tudják (Gruber és mtsai., 2010; Heijde és Ulm, 2013). A rup1rup2 dupla mutáns növényekben valóban megnőtt, míg RUP2-t túltermelő vonalakban lecsökkent az UVR8 által kiváltott HY5 és CHS génindukció. Ráadásul a RUP1 és RUP2 gének UVR8-tól, COP1-től és HY5-tól függően UV-B sugárzással indukálhatóak, így tehát éppen akkor fejtik ki gátló hatásukat, amikor az UVR8 jelátvitel elindul, ami a negatív visszacsatoló szerepüket erősíti. Meg kell azonban említeni, hogy a RUP fehérjék UV-B fénytől függetlenül is képesek kötődni az UVR8-hoz, így szerepüket valószínüleg pusztán változó mennyiségüktől függően fejtik ki (Gruber és mtsai., 2010). A RUP fehérjék hatásmechanizmusa könnyen magyarázható lenne azzal, hogy pusztán a COP1-gyel versengenek az UVR8 WD40 kötőhelyéért, de ez nem magyarázza az UVR8 által COP1-től függetlenül lezajló génindukciós folyamatok gátlását. Heijde és Ulm (2013) magyarázattal szolgált a kérdésre: a RUP fehérjék az UVR8 inaktív dimerré történő visszaalakulásában is szerepet játszanak, ugyanis a folyamat a vad típusban tapasztaltakhoz képest rup1rup2 mutáns növényekben sokkal lassabb. Ezt erősíti, hogy a RUP2-t túltermelö növényekben az UVR8 monomerek aránya alacsonyabb, mint a vad típusban. Összegezve tehát a RUP fehérjék a COP1 távoltartásával, valamint az UVR8 inaktív dimerré alakulásának gyorsítása révén fejtik ki gátló hatásukat az UVR8 által UV-B-ben elindított válaszokra.

Negatív regulátor szerepet nem csak a RUP fehérjék játszanak az UVR8 jelátvitelben. Kimutatták, hogy a WRKY DNA-BINDING PROTEIN 36 (WRKY36) fehérje kötődik a HY5 promóteréhez, ezáltal gátolja a HY5 gén átíródását. Az UVR8 a sejtmagban képes kötődni a WRKY36 fehérjéhez, ezáltal gátolva annak DNS kötését, ily módon feloldva a HY5 gént a gátlás alól. Így tehát az UVR8 nem csak a HY5 COP1 általi lebontását akadályozza meg, hanem 
WRKY36-hoz kötve képes megemelni a HY5 gén aktivitását is (Yang és mtsai., 2018), így ez a két mechanizmus hozzájárul a HY5 fehérjeszint UV-B sugárzás hatására bekövetkező emelkedéséhez. Az, hogy találtak egy újabb fehérjét, ami kölcsönhatásba lép az UVR8-cal, önmagában is érdekes, mivel eddig nagyon kevés UVR8-kölcsönható partnert sikerült csak azonosítani. (További két, eddig ismert kölcsönható partnert a 2.5.2.2. fejezetben említek).

\subsubsection{Az UVR8 DNS-kötése}

Mivel az UVR8 szerkezetéhez leginkább hasonlító RCC1 fehérje kötődik a kromatinhoz, nem volna meglepő, ha az UVR8 is képes lenne DNS kötésre (Azuma és mtsai., 1999; Cloix és Jenkins, 2008). A látszólag egyszerü és logikus következtetés ellenére az UVR8 DNS-kötése egy ellentmondásokkal átszőtt kérdéskör.

Brown és munkatársai (2005) feltételezték, hogy az UVR8 képes kötődni a kromatinhoz, így tudja a célgének átírását közvetlenül szabályozni. Később in vitro és in vivo kísérleti rendszerben kimutatták, hogy az UVR8 a H2B hisztonhoz képes legerősebben kötődni (Cloix és Jenkins, 2008). Ezek az eredmények azonban önmagukban nem elég meggyőzőek az UVR8 közvetlen génregulációs képességeit tekintve, ráadásul az alapgondolatot adó RCC1 sem DNS szekvencia specifikus területekhez kötődik, ami megkérdőjelezi az UVR8-ról feltételezett génregulációs képességet (Makde és mtsai., 2010). Az újabb eredmények is számos kérdést vetettek fel: Cloix és Jenkins (2008) kromatin-immunprecipitációs (ChIP) kísérletekkel kimutatta, hogy az UVR8 képes kötődni a kromatinhoz UV-B sugárzástól függetlenül is, ami szintén ellentmond az UVR8 UV-B-specifikus génindukáló képességének. Az előző eredmények némileg erősítenék a feltevést, ha bizonyítanák például a kötés erősségének megemelkedését UV-B hatására, de erre vonatkozó adat nem született.

Az UVR8 DNS-kötő képességére utaló eredmények tehát önmagukban sem egyértelmüek, ráadásul a legújabb kísérleti eredmények nagy részüket tételesen meg is cáfoják: Binkert és munkatársai (2016) arra a következtetésre jutottak, hogy az RCC1 fehérjével ellentétben az UVR8 nem volt képes nukleoszómákhoz kötődni in vitro, hiába hasonló a szerkezetük. ChIP kísérleteik pedig azt mutatták, hogy az UVR8 nem kötődik sem a HY5, sem a MYB12 gének promóter régióihoz, ami szöges ellentétben áll a korábban leírtakkal. Egy nemrég megjelent munkában Yang és munkatársai (2018) kísérleteinek bár nem ez volt a célja, EMSA (electrophoretic mobility-shift assay) módszerrel alátámasztották, hogy az UVR8 in vitro nem kötődik a HY5 promóteréhez. Mindezek mellett az RCC1 és UVR8 kristályszerkezetét összehasonlítva az is kiderült, hogy az egyébként sem szekvencia-specifikus kromatin kötésért felelős motívumok, amik az RCC1-ben megtalálhatóak, az UVR8-ból hiányoznak (Binkert és mtsai., 2016). 
A régi és újabb eredményeket összevetve az UVR8 DNS-kötését illetően inkább újabb megválaszolandó kérdések és kételyek, mintsem megdönthetetlen eredmények születtek az évek során, így a témakörben további vizsgálatok szükségesek a tisztánlátáshoz.

\subsection{Az UVR8 kapcsolata egyéb jelátviteli útvonalakkal}

\subsubsection{Kapcsolat a fototropinok müködésével}

A növények helyváltoztató képesség hiányában kénytelenek alkalmazkodni a változó fényviszonyokhoz, ezt többek között fototropikus növekedési válaszokkal igyekeznek megvalósítani fotoreceptoraik közremüködésével. A pozitív fototropizmus a fény felé megfigyelhető elhajlás, vagy fordulás a fotoszintézis hatékonyságának növelése érdekében, míg a negatív fototropizmus éppen ellentétesen müködik, amire a gyökér fénykerülő válasza egy ismert példa (Iino, 1990; Ahmad és mtsai., 1998; Correll és mtsai., 2003). Amellett, hogy a legismertebb fototropikus mozgások kék fény irányába történnek, a csíranövények hipokotilja az UV-B sugárzás felé is képes elhajlani (Baskin és Iino, 1987; Vandenbussche és mtsai., 2014). Mivel föleg a fototropinok szabályozzák a kék fény irányába induló fototropikus mozgásokat, ráadásul érzékelik az UV-A tartományt is, ezért az UV-B irányába történő elhajlásért először a fototropinokat tették felelőssé. A felvetés önmagában igaznak is bizonyult, a fototropinok valóban szabályozzák az UV-B irányú hipokotil elhajlást. Érdekes módon photlphot2 dupla mutánsokon végzett kísérletek alapján viszont nem kizárólag a fototropinok felelősek ezért a válaszért, ugyanis ez a mutáns is képes teljes értékủ, bár később elinduló elhajlásválaszt mutatni (Vandenbussche és mtsai., 2014). Logikus következtetés, hogy az UVR8 lehet felelös a megfigyelt elhajlásért, az uvr8 mutáns csíranövényeken végzett kísérlet eredménye azonban meglepö volt: az uvr8 növényeket nem lehetett megkülönböztetni a vad típusúaktól egyirányú UV-B kezelést követöen. Ha azonban a phot1phot2 dupla mutáns háttérben csendesítették az UVR8 gént, eltünt a photlphot2 mutánsokra jellemző, később induló UV-B irányú elhajlás. Ezek alapján a megfigyelt, fototropinoktól független elhajlásválaszért tényleg az UVR8 a felelős (Vandenbussche és mtsai., 2014). Ezek az eredmények a fototropinokra nézve is új információkkal szolgálnak, ugyanis kiderült, hogy nem csak UV-A, hanem UV-B sugárzásra is képesek reagálni. Érdekes módon ráadásul nagyon alacsony intenzitású

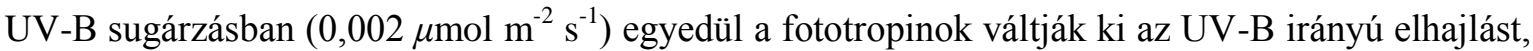
ilyen körülmények között az UVR8 nem járult hozzá a megfigyelt válaszreakcióhoz (Vanhaelewyn és mtsai., 2016).

Bár a fototropinok és az UVR8 az UV-B indukált elhajlást tekintve látszólag egymástól függetlenül müködnek, mégis kapcsolatban állnak. A negatív visszacsatolás hiánya miatt erősebb UVR8-választ adó ruplrup2 dupla mutáns csíranövények UV-B felé hajlása ugyanabban az 
időpontban kezdődik el, mint a vad típusú növényeké, sebessége az UV-B kezelés kezdete után 2 órával mégis lelassul (Vanhaelewyn és mtsai., 2016). Ez éppen az az időpont, amikor az UVR8 által kiváltott elhajlás elindul, vagyis nagy valószínüséggel az UVR8 jelátvitel elindulása gátolja a fototropinok müködését ebben az esetben. Ezt bizonyítja, hogy a fokozott UVR8 müködést mutató rup1rup2 mutánsban megfigyelhető lassulás eltủnik a rup1rup2uvr8 hármas mutánsban, tehát valóban az UVR8 müködésének elindulása lassítja a fototropinok által korábban kiváltott elhajlást (Vanhaelewyn és mtsai., 2016).

Összegezve, az UV-B irányú elhajlást kiváltó fő receptorok csíranövényekben érdekes módon a fototropinok, ennek ellenére az UVR8 is képes elhajlásválaszt kiváltani, a fototropinoktól függetlenül. A két jelátviteli út a látszat ellenére kapcsolatban áll, ugyanis az UVR8 egyértelmüen gátolja a fototropinok müködését ebben a folyamatban (Vanhaelewyn és mtsai., 2016).

\subsubsection{Kapcsolat hormonális jelátviteli utakkal}

\subsubsection{Auxin}

Az UVR8 számos folyamat szabályozásában részt vesz azáltal, hogy bizonyos hatásai összefonódnak egyéb jelátviteli utakkal. Ilyen folyamat többek között általánosságban a növekedés szabályozása (mint amilyen a fototropikus elhajlás is, a későbbiekben részletesen kifejtem), aminek egyik kulcsszereplöje az auxin növekedési hormon (Vandenbussche és Van Der Straeten, 2014). Az auxin serkenti a sejtek osztódását és megnyúlását, ezzel járul hozzá a növekedési válaszok kialakulásához, így tehát az auxin mutáns növények törpe fenotípust mutatnak: rövid levélnyelük és kicsi, vastag leveleik vannak, vagyis nagyon hasonlítanak az UV-B sugárzásnak kitett növényekre (Jansen és mtsai., 2001). Ez arra utal, hogy az auxin és az UV-B jelátvitel kapcsolatban állhat egymással. Később kiderült, hogy ez a kapcsolat nem csak létezik, hanem kifejezetten szoros a két jelátviteli rendszer között.

Az indol-3-ecetsav, vagyis az auxin fitohormon a növények fejlődését, növekedését, a fototropikus válaszokat, az apikális dominanciát, a szeneszcenciát, a virágzást, valamint sok más fejlődési választ szabályoz (Woodward és Bartel, 2005; Quint és Gray, 2006). Külső auxin kezelés hatására számos gén expressziója megemelkedik, ezek promóterében megtalálható az auxin-válasz elem, amihez az aktiváló hatású ARF (AUXIN RESPONSE FACTOR) transzkripciós faktorok kötődnek (Ulmasov és mtsai., 1997). Auxin hiányában az AUX/IAA (Auxin/Indole-3-Acetic Acid) fehérjék ARF transzkripciós faktorokhoz kötnek, gátolva az aktiváló funkciójukat (Tiwari és mtsai., 2001). Az SCF ${ }^{\mathrm{TIR} 1}$ komplex (SKP2/CULLIN/F-BOX E3 ubiquitin ligáz komplex TRANSPORT INHIBITOR RESPONSE1 (TIR1) specificitással) jelöli ki lebontásra a gátló AUX/IAA fehérjéket auxin jelenlétében, vagyis az ubiquitin ligáz komplex auxin receptorként müködik (Quint és Gray, 2006). Ezen kívül az AUXIN BINDING PROTEIN 1 (ABP1) játszik 
receptor szerepet, mint sejtfelszíni fehérje, ami a MAPK (MITOGEN-ACTIVATED PROTEIN KINASE) útvonalon keresztül indukál auxin válasz-géneket (Napier és mtsai., 2002). A legfontosabb auxin indukált géneket három géncsaládba csoportosíthatjuk: a SAUR (Small Auxin-Up RNAs), a GH3 (Gretchen Hagen 3) és az Aux/IAA (Auxin/Indole-3-Acetic Acid, Indolacetic Acid-Induced Protein) családokba (Quint és Gray, 2006).

Fototropikus hipokotil elhajlás során az auxin felhalmozódás az árnyékolt oldalon történik, ráadásul az auxin bioszintézis- és auxin válasz-gének csendesítése a megvilágított oldalon felerősödik, mindezek következtében az árnyékos oldalon tapasztalható intenzívebb megnyúlás miatt hajlik el a fény felé a hipokotil (Christie és Murphy, 2013; Goyal és mtsai., 2013; Vandenbussche és Van Der Straeten, 2014) (3. ábra). Az auxin gradiens kialakulását több folyamat befolyásolhatja: a de novo auxin szintézis és szállitás az árnyékolt oldalon, valamint a termelődés gátlása a megvilágított részen (Vandenbussche és Van Der Straeten, 2014; Woodward és Bartel, 2005). Az auxin szintézisben résztvevő kulcsenzimek génjének (például $Y U C C A=Y U C$ gének) aktivitását befolyásolva alakítható az auxin szint (Woodward és Bartel, 2005). Az auxin szállítása is kulcsfontosságú a megfelelő fejlődési válaszok kialakulásához, például a tropikus válaszokhoz (Friml és mtsai., 2003). A hormon sejtbe jutása az AUXIN RESISTANT 1 (AUX1) transzmembrán fehérjének, valamint homológjainak (LIKE AUXIN RESISTANT = LAX) segítségével történik (Marchant és mtsai., 1999; Vandenbussche és mtsai., 2010). Miután az auxin bejut a sejtbe, számos egyéb faktor, föként a PIN-FORMED (PIN) transzmembrán fehérjék szabályozzák az auxin kijutását (Chen és mtsai., 1998; Galweiler és mtsai., 1998; Abas és mtsai., 2006). Az AUX1-hez hasonlóan a PIN1 fehérje is aszimmetrikusan helyezkedik el, ezzel elősegítve az auxin poláris transzportját (Galweiler és mtsai., 1998). Az eltérő auxinválaszok kialakulásához a flavonoidok is hozzájárulnak, ugyanis gátolják az auxin bazipetális transzportját (Brown és mtsai., 2001; Jansen és mtsai., 2001; Peer és Murphy, 2007), mégpedig fényfüggő felhalmozódásuk miatt a megvilágított oldalon (lásd: 5.2.2.2. fejezet). A tapasztalatok alapján tehát az UV-B irányú elhajlásválaszokhoz is hozzájárulhat az auxin növekedési hormon, ezért DR5rev:GFP auxin riporter konstrukciót (Friml és mtsai., 2003) alkalmazva megvizsgálták az auxin müködésének helyét a hipokotilban. Vad típusban egyirányú kék fényben a jel erősebb volt a hipokotil árnyékos oldalán, photlphot2 dupla mutánsban viszont nem alakult ki auxin gradiens. UV-B fényben azonban a photlphot2 dupla mutáns növényekben is erősebb auxin jelet kaptak az árnyékos oldalon, ami bizonyítja a fototropinoktól független auxin gradiens kialakulását UV-B hatására (Vandenbussche és Van Der Straeten, 2014). Az auxin eloszlás változását kék fényben az auxin vízszintes irányú szállítása okozza, amit a PIN-FORMED 3 (PIN3) auxin efflux szállító fehérje végez (Ding és mtsai., 2011; Esmon és mtsai., 2006). Az auxin influx szállítóknak nincs szerepük a folyamatban, ugyanis az auxllax1lax2lax3 négyszeres mutáns elhajlik kék és UV-B irányába is, ami arra utal, hogy inkább az auxin efflux, mint az influx folyamatok játszanak szerepet a fototropikus elhajlásban (Vandenbussche és Van Der Straeten, 2014). 
Az auxin efflux gátlása azonban nem eredményezte az elhajlás teljes elmaradását, ami arra utal, hogy nem kizárólag az auxin eloszlásától függ a fototropikus válaszok kialakulása. Valóban bebizonyosodott, hogy az UVR8 és az auxin jelátviteli útjai kapcsolatban állnak, ezáltal az UV-B sugárzás képes jelátviteli szinten is befolyásolni az auxin hatását. Az UVR8 szabályozás alatt álló HY5 transzkripciós faktorról kiderült, hogy befolyásolja az auxin jelátvitelét, ugyanis a hy5 mutáns növényben nem expresszálódik sem az IAA7, sem pedig az IAAI4 auxin válasz-gén (Cluis és mtsai., 2004; Halliday és mtsai., 2009; Sibout és mtsai., 2006; Vanhaelewyn és mtsai., 2016).

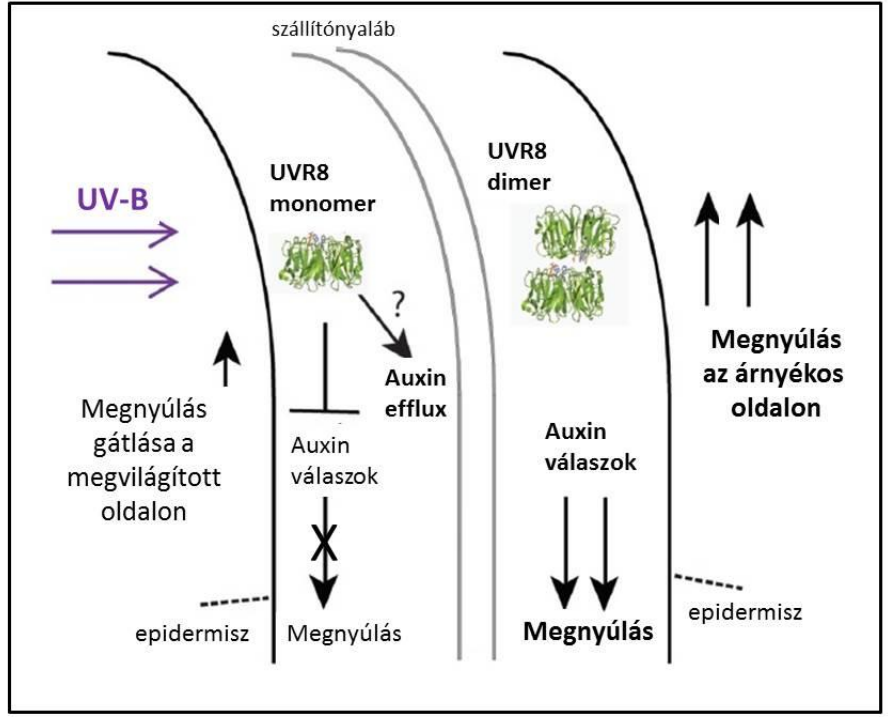

3. ábra: Az egyirányú UV-B sugárzásban UVR8 által indukált fototropikus elhajlás modellje Vandenbussche és mtsai. (2014) alapján

Az UVR8 és az auxin kölcsönhatásának köszönhető a hipokotil elhajlása. A megvilágított oldalon az UVR8 aktív monomerjeinek aránya magasabb, mint az árnyékos oldalon. Az aktív UVR8 gátolja az auxin által kiváltott növekedési válaszokat, emiatt a megvilágított oldali növekedés elmarad az árnyékos oldalon bekövetkezö növekedéstől. Ennek az egyenetlen növekedésnek köszönhető az UV-B irányba történő fototropikus elhajlás.

Az auxin jelátvitelét természetesen nem csak az UV-B sugárzás befolyásolja, mint ahogy az ki is derült a fototropinokkal kapcsolatban. Az UV-B sugárzás és kék fény mellett a vörös fény is szabályozza a növekedési válaszokat. Ez nem meglepő, mivel a phyB és az UVR8 jelátviteli útja nem csak hogy kapcsolatban áll, hanem nagyjából 70\%-ban a bennük résztvevő faktorok is közösek (Fierro és mtsai., 2015). A levél epinasztia (levélszélek lehajlása) szabályozásában például -aminek létrejöttében az auxin eloszlásnak van fontos szerepe- az UVR8 és a phyB jelátvitel egymással összhangban müködik. Az UV-B hatására történő epinasztia uvr8 mutánsokban nem figyelhető meg, tehát ez egy UVR8 által szabályozott mechanizmus. Meglepő azonban, hogy phyB mutáns növényekben szintén nem történik meg a levélszél lehajlás UV-B hatására. A phyB hiánya tehát lehetetlenné tette az UVR8 által szabályozott epinasztia kialakulását, ugyanúgy, ahogy a phyB jelátvitelben szereplö negatív szabályozó faktor, a PHYTOCHROME INTERACTING 
FACTOR 5 (PIF5) fehérje túltermeltetése is (Fierro és mtsai., 2015). Nem meglepő tehát, hogy a fitokróm jelátvitelben szereplö PIF transzkripciós faktorok mennyiségét is szabályozza az UVR8: a PIF4 és a PIF5 valóban lebomlik UV-B sugárzás hatására (Hayes és mtsai., 2014). Ráadásul célgénjeik szabályozását ugyanazokhoz a G-box elemekhez kötve végzik, mint melyekhez a HY5 is köt, ezáltal befolyásolják egymás müködését, mivel általában ellentétes hatásúak (Hayes és mtsai., 2014; Toledo-Ortiz és mtsai., 2014). A PIF4, a PIF5 és a PIF7 több, auxin jelátvitelben (IAA19, IAA29) és bioszintézisben (YUC2, YUC5, YUC8, YUC9) szereplő gén promóteréhez képes kötni, ezáltal aktiválni azokat, így befolyásolva az auxin által kiváltott növekedési folyamatokat fényfüggő módon (Hornitschek és mtsai., 2012; Sun és mtsai., 2013). A PIF fehérjék fénytől/UV-B sugárzástól függő lebomlása tehát segíti a HY5 auxinválaszra gyakorolt gátló hatását.

Az auxin jelátvitel a PIF4 révén nem csak fotomorfogenikus, hanem termomorfogenikus, vagyis hőmérséklettől függő növekedési válaszokkal is kapcsolatban áll: a PIF4 kulcsszereplője a melegben $\left(28{ }^{\circ} \mathrm{C}\right) \quad$ megfigyelhető hipokotil megnyúlás, illetve levélnyél megnyúlás szabályozásának (Hayes és mtsai., 2017). Azon túl, hogy az UV-B sugárzás hatására lebomlik a PIF4 fehérje, a PIF4 génnek az átíródása is gátlódik UVR8-függő módon. Ráadásul az UVR8 aktiválása következtében a LONG HYPOCOTYL IN FAR-RED 1 (HFR1) fehérje stabilitását is növeli, ami pedig a PIF4-gyel heterodimert kialakítva gátolja annak müködését. Ezek a különbözö gátló hatások együtt elegendőek ahhoz, hogy a melegben észlelhető, PIF4-től függő termomorfogenikus hipokotil nyúlást az UV-B sugárzás teljes mértékben gátolja (Hayes és mtsai., 2017).

Az előzőek mind közvetett szabályozási formák abban a tekintetben, hogy az UVR8 által elindított jelátviteli út bizonyos résztvevője, vagy azzal kölcsönhatásban álló egyéb faktor müködése közvetítette az UVR8 hatását. Mivel azonban az UVR8 feltételezett DNS-kötö képessége révén közvetlenül is képes lehet gének szabályozására, nem zárhatjuk ki a lehetőségét, hogy ilyen gének az auxin jelátvitelében, vagy bioszintézis útjaiban is szerepelnek. Ebből kiindulva kvantitatív valós idejü RT-PCR módszerrel olyan géneket vizsgáltak, amelyek müködése megváltozik UV-B és auxin jelenlétében is. Több olyan gént (IAA19 IAA29, SAUR23, SAUR27) is találtak, amiket vad típusú növényben gátolt az UV-B sugárzás, míg uvr8 mutáns növényben ez nem történt meg (Vandenbussche és mtsai., 2014). Valószínủ tehát, hogy az auxinválaszt az UVR8 jelátvitel gének szintjén is képes befolyásolni, még ha nem is az UVR8 DNS-kötő képessége révén.

\subsubsection{Kapcsolat egyéb hormonok jelátviteli rendszerével}

A gibberellinek legfőbb funkciója a csírázás elősegítése, valamint a virágzás indukálása, emellett a gibberellin jelátviteli útvonal a növekedést is serkenti a gátló hatású DELLA fehérjék lebontásának elősegítése által (Hauvermale és mtsai., 2012). Az UV-B sugárzás, nagy valószínüséggel HY5-függő úton, gibberellin inaktiváló enzimek (például a GIBBERELLIN 2- 
BETA-DIOXYGENASE 1 = GA2oxl) génjeit indukálja, aminek következtében megemelkedik a DELLA proteinek szintje (Ulm és mtsai., 2004; Weller és mtsai., 2009; Hayes és mtsai., 2014), ami a növekedés gátlásához vezet. A DELLA fehérjékről kimutatták, hogy több módon is gátolják a növekedést serkentő PIF fehérjék működését (Mazza és Ballare 2015; Li és mtsai., 2016). Mivel az UVR8 befolyásolja a HY5 és a PIF-ek mennyiségét is, így az UVR8 és a gibberellinek jelátvitele több ponton is összekapcsolódik.

A brasszinoszteroidok növekedést serkentő hormonok, emellett szabályozzák a szkotomorfogenezis-fotomorfogenezis átmenetet is (Luo és mtsai., 2010). Az UVR8 a brasszinoszteroidok jelátvitelével is kapcsolatban áll. Ezt bizonyítja, hogy a BRASSINOSTEROID INSENSITIVE 1 (BRI1) hormonreceptor és az UVR8 jelátvitel kulcsszereplője, a COP1 képes kölcsönhatni egymással, ráadásul sötétben a COP1 köt a BRASSINAZOLE-RESISTANT 1 (BZR1) transzkripciós faktor foszforilált, inaktív formájához, aminek következtében utóbbi lebomlik. Ez a defoszforilált, aktív BZR1 túlsúlyát eredményezi, ami elősegíti a növekedést sötétben (Li és He, 2016). Az UVR8 ezt a folyamatot gátolja meg a COP1 ubiquitináló hatását csökkentve. A növekedés gátlás másik módja, hogy az UVR8 UV-B hatására kiváltja a HY5 szint emelkedését, a HY5 pedig gátló hatást gyakorol a brasszinoszteroid jelátvitelre azáltal, hogy az aktív állapotú BZR1 faktorhoz köt, így inaktiválva azt (Li és He, 2016). Mindezek mellett a BZR1 képes a PIF4 fehérjével is kölcsönhatásba lépni, utóbbinak az UVR8 szintén befolyásolja a mennyiségét (Oh és mtsai., 2012). Az UVR8 közvetlenül is képes brasszinoszteroid jelátvitelében szerepet játszó transzkripciós faktorokhoz kötni, ezáltal gátolni a brasszinoszteroidok növekedést serkentő hatását: a BRI1-EMS SUPPRESSOR 1 (BES1) és a BES1-INTERACTING MYC-LIKE 1 (BIM1) brasszinoszteroid szabályozás alatt álló, növekedést serkentő transzkripciós faktorok, melyekhez az UVR8 kapcsolódni képes, így gátolva utóbbiak DNS-kötését (Liang és mtsai., 2018; Yang és mtsai., 2018).

Szintén a növekedésre ható hormonok a citokininek. Szerepük van a sejtosztódás és a sejtmegnyúlás serkentésében, a sejtek differenciálódásának szabályozásában. Az UVR8 jelátvitelével közvetve és közvetlenül is összefonódik a citokininek müködése, ugyanis több citokinin-oxidáz gén is PIF4, PIF5, valamint PIF7 szabályozás alatt áll, továbbá a flavonoid bioszintézist befolyásolják, ráadásul a citokininek hatnak a HY5 transzkripciós faktor működésére is (Vandenbussche és mtsai., 2007; Hornitschek és mtsai., 2012).

Az etilén egy olyan gázhormon, aminek termelődése fokozódik UV-B sugárzás hatására (Mackerness és mtsai., 1999). Szerteágazó funkciói ismertek a morfogenezis és a stresszválaszok terén is. Az etilén jelátviteli rendszere szintén kapcsolatban áll az UV-B sugárzás hatásával: az ETHYLENE-INSENSITIVE 2 (EIN2) az etilén jelátvitel pozitív hatású résztvevője, aminek hiánya megemelkedett flavonoid felhalmozódást eredményez UV-B hatására (Sun és mtsai., 2011). Az EIN2 által aktivált, szintén pozitív hatású ETHYLENE-INSENSITIVE 3 (EIN3) pedig a PIF3 
fehérjét aktiválva képes a hipokotil megnyúlást befolyásolni (Zhong és mtsai., 2012). Az etilén a COP1 müködését is segíti, ami szintén a fotomorfogenikus válaszokat gátolja (Yu és mtsai., 2013).

Az abszcizinsav a növények stresszhormonja, így tehát szintje UV-B stressz hatására is megemelkedik a növényekben (Rakitina és mtsai., 2004; Tossi és mtsai., 2009; Dinh és mtsai., 2013). Az abszcizinsavnak fotoprotekcióban betöltött szerepét támasztja alá, hogy az abszcizinsav bioszintézisben mutáns növények érzékenyebbek az UV-B sugárzásra (Tossi és mtsai., 2009). A molekuláris szintű kapcsolatot az UVR8 és az abszcizinsav jelátvitele között a HY5 biztosítja, ugyanis a hy5 mutáns növények rezisztensek az abszcizinsavra (Chen és mtsai., 1998). A stresszválaszok szorosan összefüggnek ROS-ok képződésével is, ami további UVR8 jelátviteli kapcsolatokra enged következtetni. A fennálló kapcsolatok ellenére azonban meg kell állapítanunk, hogy az abszcizinsav termelésének fokozódása UV-B-ben inkább általános stresszválasz, mintsem specifikus UV-B-válasz.

A szalicilsav és a jázmonsav a növények stresszhormonjai, amelyeknek legfontosabb szerepük a biotikus stressz (növényi kártevők) elleni védekezés szabályozásában van. Számos esetben az UV-B sugárzás pozitívan befolyásolja a növények védekezőképességét az ilyen stresszfaktorok ellen (Ballare és mtsai., 2012). Egy friss összehasonlító elemzés alapján a szalicilsav és a jázmonsav kezelések hasonló génregulációs folyamatokat indítanak el, mint az UV-B sugárzás. Az RNAseq adatbázisok összehasonlítása alapján számos olyan gén regulációja megtörténik biotikus stressz következtében, amiket az UVR8 is szabályoz, ennek köszönhetően a növény (megfelelő dózisú) UV-B kezelés segítségével hatékonyabban tud védekezni bizonyos kártevők ellen (Vandenbussche és mtsai., 2018). Mindezek alapján a jelátviteli rendszerek összefonódása egyértelmünek látszik.

Összességében levonhatjuk azt a következtetést, hogy a növekedésre ható hormonok működését az UV-B sugárzás gátolja, ezáltal hozzájárulva a fotomorfogenikus válaszok kialakulásához. A stresszválaszokhoz kapcsolt hormonok müködését ellenben elösegíti az UV-B sugárzás. Mindent összevetve az adatok tükrében kijelenthetjük, hogy az UV-B-válaszok kialakulásához nagyban hozzájárul a hormonális rendszer és az UVR8 jelátviteli hálózat összehangolt müködése.

\subsubsection{Kapcsolat egyéb jelátviteli folyamatokkal}

Az, hogy az UVR8 hozzájárul az UV-B elleni védekezéshez a flavonoidok felhalmozódása által, kiderült a korábbi fejezetekből. Ezt a funkcióját azonban más fotoreceptorok is befolyásolják: az UVR8 által serkentett $C H S$ génexpressziót a vörös fény gátolja, míg az UV-A és a kék fény elősegíti (Wade és mtsai., 2001). Tekintve, hogy az UVR8 számos gén müködését befolyásolja, nem meglepö, hogy az UV-B elleni összetett védekezési válaszokban is fontos szerepet játszik. Az UVR8 fehérje valóban segíti a növények UV-B akklimációját: kimutatták, 
hogy az uvr8 mutáns növényeket a kísérletben használt intenzitású UV-B sugárzás komolyan károsítja, míg az UVR8 túltermelő növények ugyanolyan körülmények között megemelkedett UV-B toleranciaszintet mutattak (Favory és mtsai., 2009). Annak ellenére, hogy ezt a témakört nem a hormonokkal foglalkozó fejezetben említem tág mivolta miatt, kétségtelen, hogy legalább közvetett módon bizonyos részfolyamatok szabályozásához a hormonális rendszer tagjai is hozzájárulnak.

Az $u v r 8$ mutánsok csökkent fotoszintetikus aktivitással rendelkeznek UV-B sugárzásban, amire az a magyarázat, hogy számos, színtestben található fehérjét kódoló gén is UVR8 általi szabályozás alatt áll (Davey és mtsai., 2012). Érdekes jelenség, hogy bár az UV-B sugárzás UVR8 független úton kisebb levélméretet okoz, az $u v r 8$ mutáns növények a várakozással ellentétben kisebb levélmérettel rendelkeznek, mint a vad típusú növények. Ezek alapján az UVR8 hatása, bár kisebb mértékben, de éppen ellentétes egy szintén UV-B által kiváltott folyamatra nézve (Wargent és mtsai., 2009). Ez a példa is az UV-B által kiváltott válaszok szabályozási hálózatának bonyolultságát érzékelteti.

Mindent összevetve megállapíthatjuk, hogy az UVR8 UV-B receptor számos folyamatot befolyásol a növények teljes életciklusa során. Müködéséhez elengedhetetlen az egyéb fotoreceptorokkal, valamint a hormonokkal átfedő bonyolult jelátviteli hálózat. Az UVR8 hozzájárul a növények optimális növekedéséhez és fejlődéséhez, valamint segíti az UV-B sugárzás károsító hatásainak kivédését. Az esetlegesen mégis bekövetkező (makromolekulák sérüléséből adódó) károk enyhítésére irányuló folyamatok szabályozásában szintén fontos szerepet játszik a növények UV-B receptora, az UVR8.

\subsection{Az UVR8 jelátviteli hálózatának összefoglalása}

Az UV-B sugárzás hatására az UVR8 és a COP1 szintje megemelkedik a sejtmagban, az UVR8 sejtmagi importjához nélkülözhetetlen a COP1 jelenléte. Az inaktív UVR8 dimerek aktív monomerré alakulva kötődnek a COP1 E3 ubiquitin ligázhoz, gátolva annak lebontásra kijelölő, ubiquitináló funkcióját. Ennek következtében minden COP1 általi gátlás alatt álló fehérje szintje megemelkedhet, ilyen például a HY5, fotomorfogenezist serkentő transzkripciós faktor is. A kulcsszerepet játszó HY5 aktiválásához más, gátló faktorok müködésének visszafogása is hozzájárul, mint amilyen például a WRKY36. Pozitív visszacsatolásként a HY5 elősegíti saját maga és nagy valószínüséggel a HYH termelődését (lásd az eredményeknél, az 5.2.3. fejezetben) (Binkert és mtsai., 2014). A HY5 révén bonyolult hálózat irányítása történik meg a PIF transzkripciós faktorokra és növekedési hormonokra gyakorolt hatásán keresztül, amelyek leginkább növekedési válaszokat befolyásolnak. Az UVR8, eddig tisztázatlan mechanizmusok segítségével számos olyan folyamatot is irányít, amik HY5-tól függetlenek. Ilyen például a $P R R 9$ óragén aktiválása. A RUP fehérjék negatív visszacsatolást biztosítanak azáltal, hogy gátolják az 
UVR8-COP1 interakciót és gyorsítják az UVR8 redimerizálódását, vagyis inaktiválódását (4. ábra).

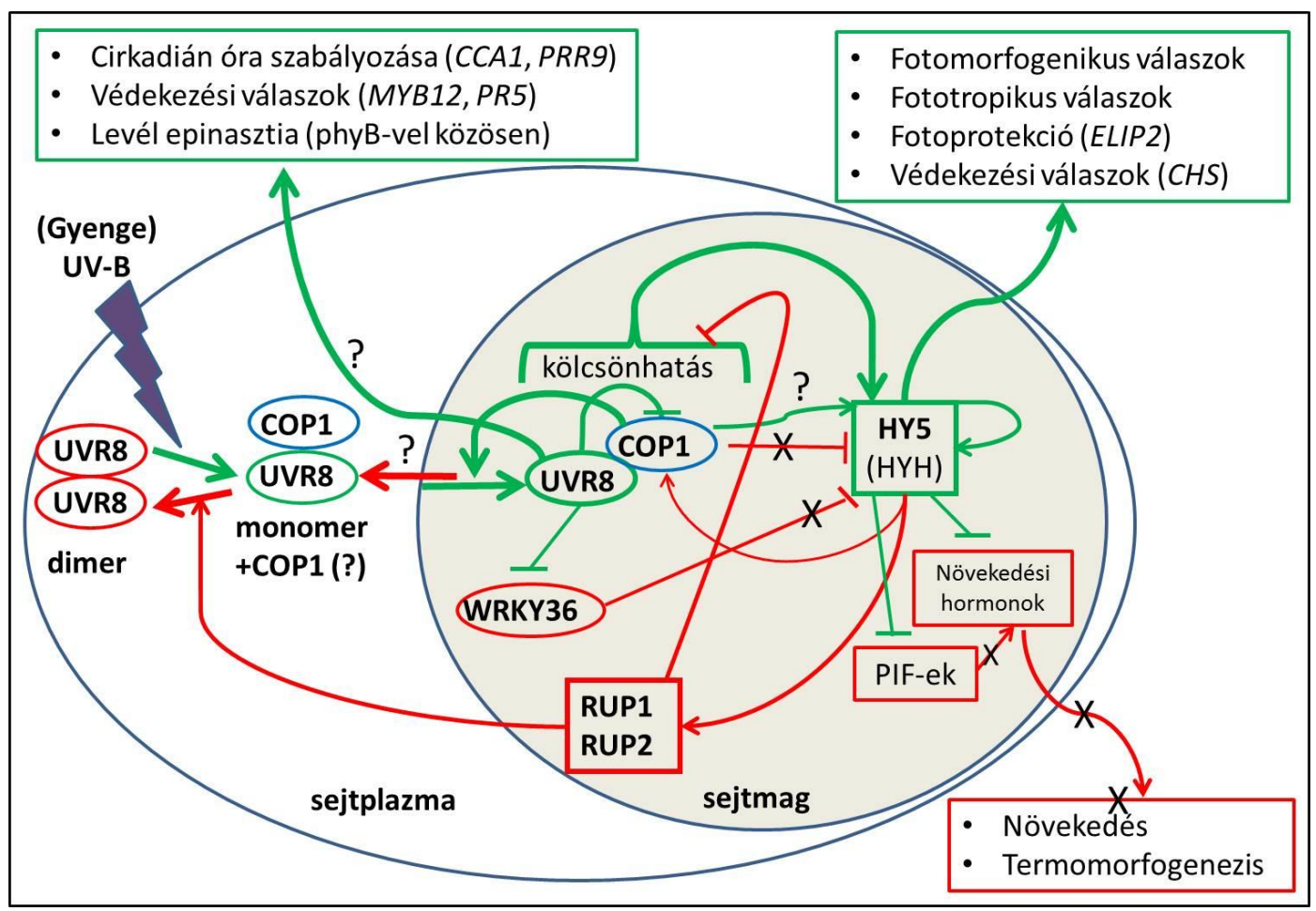

4. ábra: Az UVR8 által elindított jelátviteli folyamatok sematikus modellje

A nyilak aktiválást, a talpas nyilak gátlást mutatnak. A nyilak vastagsága a folyamatok jelátvitelben betöltött fontosságát szimbolizálják. A zöld színnel ábrázolt jelátviteli folyamatok és faktorok az UVR8 hatásait segítik, míg a pirossal jelöltek gátolják azokat. A COP1 kettős szerepe miatt kék jelölést kapott. A zöld keretekben felsorolt folyamatokat az UVR8 kiváltja, illetve serkenti, a piros keretben felsorolt folyamatokat az UVR8 gátolja. Az UVR8 és a COP1 között létrejövő kölcsönhatás és ennek hatása a HY5-ra kulcsfontosságú ezért külön ki van emelve. Az X-szel áthúzott folyamatok addig müködnek, amíg az UVR8 inaktív, az UVR8 aktivitása következtében ezek a folyamatok gátlódnak. A kérdőjellel jelölt folyamatok molekuláris háttere egyelőre nem tisztázott. Bővebb magyarázat a 2.6 fejezetben.

\subsection{Szövettípusoktól függő folyamatok a}

\section{fényérzékelésben}

\subsubsection{Példák szöveti-, vagy szervi autonómiát mutató folyamatokra növényekben}

A fény a beérkezési helytől távoli szövetekben is, akár az egész növényre hatást gyakorló változásokat képes okozni. Energiaforrásként tekintve a fényre egyértelmü, hogy a fény által termelt energia a növény minden szervéhez eljut, azokhoz is, amelyek nem érintkeznek fénnyel. A hosszan tartó, erős fény a korábban bemutatott példák alapján stresszt okoz, ROS-ok 
keletkezését és sok egyéb, káros következményekkel járó folyamatot vált ki az egész növényben, amelyek ellen összetett védekező válaszok is elindulnak (Bornmann 1997; Hollósy 2002; Mittler 2002; Britt 2004; Jenkins 2009; Hideg és mtsai. 2013). Mint ahogyan az előző fejezetben bemutatott példák is alátámasztják, a fény, mint jel sem csak ott okoz változásokat, ahol a növény érzékeli azt a fotoreceptorai segítségével. A fotoreceptorok által kiváltott válaszok a növény fejlődését, növekedését befolyásolják, amik összetett szabályozást igényelnek, ráadásul a különböző jelátviteli utak összehangolt működése is szükségs (Li és mtsai., 2011). A fény hasonló hatásai a gyökérben is megfigyelhetők: nagy intenzitású UV-B sugárzás hatására gyökérnövekedés gátlás történik Arabidopsisban, miközben a gyökeret közvetlenül nem éri fény (Ge és mtsai., 2010; Krasylenko, és mtsai., 2012). A gyökérben egyébként szintén található UVR8 fehérje (Rizzini és mtsai., 2011), aminek valószínüleg a gyökér fénykerülő fototropikus válaszában van szerepe (Yokawa és Baluska, 2015).

Számos esetben az összetett szabályozási folyamatok létrejöttéhez is bizonyos szövetekre kizárólagosan jellemző részfolyamatok összessége vezet, amelyek a szövetek közti kommunikáció révén kapcsolatban is állhatnak. Erre érzékletes példa a növényi szerveket alkotó összes szövettípus önálló, mégis koordinált fejlődése, aminek eredménye az adott szerv vagy szervrendszer, például a levelek kialakulása (Bai, és mtsai., 2010; Breuninger és Lenhard, 2010; Uchida és mtsai., 2012). Szövetautonómnak tekintjük azokat a folyamatokat, amelyek kizárólag abban a szövetben/sejttípusban jelennek meg, amelyben a választ elindító faktor megtalálható, vagy azokat, amelyek esetében a vizsgált faktor egy adott választ csak akkor képes kiváltani, ha egy bizonyos szövetben/szervben jelen van. A legtöbb fényregulált válaszreakció nagyon összetett, ezért sokszor előfordul, hogy bizonyos részfolyamatok szövetekre jellemzően mennek végbe, míg a teljes értékü válaszhoz a jelek terjedése is szükséges, ami nem egyenlő a különböző részfolyamatok párhuzamos lefutásával. Erre az összetettségre kiváló példa a növények árnyékkerülési válasza, amit a fitokrómok szabályoznak a PIF-ek segítségével, főleg az auxin szintézis gének müködésének befolyásolása által (Lorrain és mtsai., 2008; Tao és mtsai., 2008; Casal, 2013; Kim és mtsai., 2018). Míg a választ, aminek része a virágzás serkentése is, a mezofillben található phyB elindítja, addig a szállítószövetekben található phyB egyáltalán nem befolyásolta a virágzás idejét (Endo és mtsai., 2005; Smith és Whitelam, 1997). A szöveti autonómia mellett a szövetek közti kommunikáció is jelen van az árnyékkerülési válasz során, ugyanis kiderült, hogy a mezofillben lévő phyB képes a szállitószövetekben csökkenteni a FLOWERING LOCUS T (FT) gén müködését, ami pedig a virágzás egyik kulcsgénje (Cerdan és Chory, 2003; Endo és mtsai., 2005). Ráadásul azt is kimutatták, hogy az árnyékkerülési válasz során a szállítószövetekben jóval több gén müködése fokozódott, mint a mezofillben, vagy az epidermiszben. A gének többsége auxin-válaszgén volt, tehát a növekedési választ segítették (Kim és mtsai., 2018). A válaszreakció végeredménye is szervek szintjén szerveződik, ugyanis transzkriptóma analízis segítségével megállapították, hogy az árnyékkerülési reakció alatt a hajtáscsúcsban sokkal több gén múködése fokozódott, mint a 
levélben (Nito és mtsai., 2015). Könnyen beláthatjuk, hogy bár jelen van a szöveti autonómia a szabályozásban, a jelek terjedése nélkül ez, az egész növényre ható összetett válaszreakció, nem jöhetne létre.

A virágzás idejének szabályozásában a CRY2 is részt vesz, bár más szövetben érvényesíti a hatását, mint a phyB. CRY2-GFP (GREEN FLUORESCENT PROTEIN = GFP) fúziós fehérjét a szállítószöveti részben kifejeztetve a cry2 mutáns növények késői virágzás fenotípusát sikerült helyreállítani, míg ugyanez nem sikerült sem az epidermiszben, sem a mezofillben termeltetett CRY2-GFP-vel. A tapasztalt szöveti autonómia az FT CRY2 általi indukciójára is érvényes, ugyanis a szállítószövetben termeltetett CRY2-GFP csak a szállítószövetben emelte meg az FT expresszióját (Endo és mtsai., 2007). A phyB-hez hasonlóan a CRY2 is szövetautonóm módon szabályozza a virágzás idejét, de érdekes módon hatása nem ugyanabban a szövetben érvényesül, mint a phyB-é. Ez remekül példázza, hogy ugyanazt a választ különböző fajtájú szabályozási módok és faktorok egyidejűleg is befolyásolhatják, amik végül kialakítanak egy összetett válaszreakciót.

Korábban megállapították, hogy a PHOT1 az Arabidopsis hipokotiljának minden sejtrétegében előfordul (Sakamoto és Briggs, 2002; Wan és mtsai., 2008), ráadásul a fototropikus elhajlást gyenge kék fényben az epidermális, a mezofillben található, valamint az endodermális PHOT1 is el tudja indítani (Preuten és mtsai., 2013). Ennek ellenére bizonyos folyamatokban a fototropinok müködésére is jellemző a szöveti autonómia. Kék fényben a levélben található paliszád parenchima (oszlopos sejtek a mezofillben, a felső epidermisz alatt) sejtek hengeres alakot vesznek fel, ehhez a PHOT2-re van szükség. Azt is kimutatták, hogy ezt a választ csak a mezofillben lévő PHOT2 indítja el, az epidermiszben található PHOT2 nem, vagyis a szabályozás szövetautonóm módon zajlik (Kozuka és mtsai., 2011).

Számos, korábbi eredmény utalt arra, hogy érdemes megvizsgálni a phyA távoli vörös receptor szöveti szintü funkcióit. Már 1993-ban Nick és munkatársai arra a következtetésre jutottak, hogy mustár csíranövények sziklevelét távoli vörös „microbeam” sugárzással kezelve a kalkon szintáz gén átíródása sejtautonóm módon történik (Nick és mtsai., 1993). Szövetautonóm folyamatokra utaló eredményeket hozott az a kísérlet, amiben zab (Avena sativa) phyA receptorát dohányban, különböző szervekben termeltették, aminek következtében egymástól eltérő fenotípus változásokat tapasztaltak. Kimutatták továbbá, hogy a szállítószövetben található phyA gátolja a gibberellin jelátvitelt, ennek következtében befolyásolja a növekedést (Jordan és mtsai., 1995).

A phyA szövetspecifikus müködésének átfogó vizsgálatát a közelmúltban végezték el (Kirchenbauer és mtsai., 2016). Kimutatták, hogy az epidermiszben található phyA önmagában felelős a gyökérnövekedés befolyásolásáért, a mezofillben és a szállítószövetekben található phyA nem volt képes helyreállítani a phyA mutáns háttér fenotípusát. Az epidermális phyA fontos, de nem kizárólagos szerepet játszik a sziklevél kiterülésében, valamint a hipokotil megnyúlás gátlásában, ugyanis a mezofillben és a szállítószövetben található phyA hozzájárulása szükséges a 
teljes értékü válaszok kialakulásához (Kirchenbauer és mtsai., 2016). A kék fény felé történő fototropikus elhajlásban a phyA is szerepet játszik, ugyanis a vörös/távoli vörös mellett a kék tartományban is van egy abszorpciós csúcsa (Janoudi és mtsai., 1997; Kami és mtsai., 2012). Az eredmények alapján, érdekes módon sem az epidermális, sem a szállítószöveti phyA nem járul hozzá a hipokotil elhajláshoz, egyedül a mezofillben található phyA volt képes a választ indukálni (Kirchenbauer és mtsai., 2016). A phyA által elindított jelátvitelben központi szerepet játszik a HY5: távoli vörös fény hatására a HY5 gén átíródása és a HY5 fehérje szintje megemelkedik. Emellett a szkotomorfogenezist szabályozó PIF-ek szintje lecsökken, tehát összességében fotomorfogenikus válaszok indulnak el a növényben (Osterlund és mtsai., 2000; Leivar és mtsai., 2012). Távoli vörös fény hatására a HY5 szint emelkedése és a PIF-ek lebomlása csak azokban a szövetekben volt megfigyelhetö, ahol a phyA jelen volt, tehát az ezeket irányító molekuláris mechanizmusok egyetlen tagja sem lépett ki abból a szövetből, ahol a fényérzékelés megtörtént, ami bizonyítja a szöveti autonómiát (Kirchenbauer és mtsai., 2016).

Szövetek közötti jelterjedésre is találhatunk példát a phyA jelátvitelében: távoli vörös fényben, vad típusú növényhez hasonlóan, a phyA-t kizárólag epidermiszben termelö transzgenikus csíranövények esetében megfigyelhető volt a GA2oxl gén indukciója az epidermisz mellett az epidermisz alatti rétegekben is (Kirchenbauer és mtsai., 2016). Hasonló eredmény született a XYLOGLUCAN ENDOTRANSGLUCOSYLASE/HYDROLASE 17 (XTH17) génnel kapcsolatban is, ami etiolált csíranövényekben a növekedő szervekben a sejtfal kialakításában vesz részt. Etiolált csíranövényekben az XTH17 gén a hipokotilban aktív, míg a sziklevelekben inaktív volt. A távoli vörös kezelés a sziklevelekben megemelte, míg a hipokotilban csökkentette az XTH17 aktivitását, érdekes módon utóbbi szervnek csak a mezofill rétegében, annak ellenére, hogy a phyA-t epidermiszben termelő transzgenikus növények mezofilljében nem volt detektálható mennyiségü phyA (Kirchenbauer és mtsai., 2016). Ebben az esetben a szöveti autonómia helyett szövetek közti jelterjedés és inkább szerv szintű specifikus szabályozás figyelhető meg.

Mindezek tükrében levonhatjuk azt a következtetést, hogy összetett válaszreakciók tekintetében nehéz kijelenteni, hogy lefolyásuk szövet-, esetleg szervautonóm-e, érdemesebb részfolyamatokra koncentrálni ilyen célú vizsgálatok során. 


\section{CÉLKITÜZÉSEK}

A Föld felszínét elérő UV-B sugárzás növényekre gyakorolt hatása kiemelten kutatott terület. Napjainkban kitüntetett figyelmet élveznek azok az élettani vizsgálatok, melyek az UV-B sugárzás hatását nem stresszorként, hanem jelként elemzik. A kis intenzitású UV-B sugárzás számos növekedési és fejlödési folyamatot szabályoz anélkül, hogy komolyabb károsodást okozna, viszont kiváltja a növények akklimáció érdekében bekövetkező védekező válaszait. Az UVR8 UV-B fotoreceptor azonosítása óta kifejezetten erősen kutatott területté vált az UV-B által irányított jelátviteli utak felderítése.

Több fotoreceptorral kapcsolatban számos adat áll rendelkezésre különböző szövetekben lejátszódó jelátviteli folyamatokról. Ezek felderítéséhez nagyon jól alkalmazható in vivo módszer a szövetspecifikus promóterek által müködtetett riporter konstrukciók alkalmazása transzgenikus növényekben. Ilyen növényi vonalak felhasználásával vizsgálhatjuk, hogy milyen válaszért melyik szövet(ek)ben található receptor a felelős. Az UVR8 fotoreceptorral kapcsolatban eddig nem álltak rendelkezésre szövetspecifikus működésével kapcsolatos adatok, ráadásul az UVR8 jelátviteli folyamataira vonatkozó információk is hiányosak. Ezek vizsgálatára az UVR8 saját promóterével és egyéb, széles körben használt szövetspecifikus promóterek segítségével kifejeztettük az YFP-UVR8 kimérafehérjét transzgenikus uvr8 mutáns növényekben. Ezekkel a növényekkel, illetve más, az UVR8 irányította jelátviteli utakban szerepet játszó komponenseket kifejező transzgenikus növények vizsgálatával célul tüztük ki, hogy:

1. felderítsük az UVR8 mennyiségének eloszlását a különböző szövetekben;

2. megvizsgáljuk az UVR8 szövetspecifikus hatásait fotomorfogenikus, akklimációs és fototropikus válaszokra;

3. felderítsük az UVR8 funkcióira vonatkozó, csíranövényekben és felnőtt növényekben mutatkozó esetleges különbségeket;

4. riporter konstrukciók segítségével megvizsgáljunk néhány, az UVR8 irányította jelátvitelben szereplő gén kifejeződésének mintázatát;

5. megfigyeljük a felnőtt növények UV-B indukálta fototropikus válaszát és a mögötte álló molekuláris szintü változásokat. 


\section{ANYAGOK ÉS MÓDSZEREK}

\subsection{Kísérleti anyagok és élőlények}

\subsubsection{Tápoldatok, táptalajok, antibiotikumok}

\subsubsection{Bakteriális tápoldatok}

$\underline{\text { LB }}$ (Luria-Bertani medium) $(\mathrm{pH}=7,0): 1 \% \quad(\mathrm{w} / \mathrm{v})$ tripton (Molar Chemicals, Budapest, Magyarország), 0,5\% (w/v) élesztő kivonat (Molar Chemicals), 1\% (w/v) NaCl (Molar Chemicals); táptalajhoz 1,5\% (w/v) agar (Molar Chemicals).

$\underline{\text { YEB }}$ (Yeast Extract Beef) (pH=7,0): 0,5\% (w/v) Difco ${ }^{\mathrm{TM}}$ beef extract (Fisher Scientific, Hampton, $\mathrm{NH}$, Egyesült Államok), 0,5\% (w/v) szaharóz (Molar Chemicals), $2 \mathrm{mM} \mathrm{MgSO}_{4}$ (sterilre szürve); táptalajhoz: $1,5 \%(\mathrm{w} / \mathrm{v})$ Difco $^{\mathrm{TM}}$ Bacto $^{\circledR}$-agar (Fisher Scientific).

\subsubsection{Növényi táptalajok}

1/2MS1 (Murashige-Skoog Medium) $(\mathrm{pH}=5,6): 2,15 \mathrm{~g} / \mathrm{L}$ MS por (Sigma-Aldrich, St. Louis, Missouri, Egyesült Államok), 1\% (w/v) szaharóz, 0,8\% (w/v) Difco ${ }^{\mathrm{TM}}$ agar (Fisher Scientific).

$\underline{\text { MS3 }}$ (Murashige-Skoog Medium) (pH=5,6): 4,3 g/L MS por (Sigma-Aldrich), 3\% (w/v) szaharóz, $1 \%(\mathrm{w} / \mathrm{v})$ Difco $^{\mathrm{TM}}$ agar (Fisher scientific).

$\underline{\mathrm{AM}}$ (Arabidopsis Medium) (pH=5,6): 2,15 g/L MS por, 1\% (w/v) szaharóz, 0,2\% (w/v) phytagel (Sigma-Aldrich).

\subsubsection{Antibiotikumok}

Escerichia coli: Ampicillin (Amp) $100 \mu \mathrm{g} / \mathrm{mL}$ végkoncentrációban, Kanamicin (Km) $50 \mu \mathrm{g} / \mathrm{mL}$ végkoncentrációban.

Agrobacterium tumefaciens: Karbenicillin (Cb) $100 \mu \mathrm{g} / \mathrm{mL}$ végkoncentrációban, Kanamicin $(\mathrm{Km})$ $50 \mu \mathrm{g} / \mathrm{mL}$ végkoncentrációban, Rifampicin (Rif) $25 \mu \mathrm{g} / \mathrm{mL}$ végkoncentrációban.

Arabidopsis thaliana: Higromicin (Hyg) $15 \mu \mathrm{g} / \mathrm{mL}$ végkoncentrációban, Klaforán (Cf) $200 \mu \mathrm{g} / \mathrm{mL}$ végkoncentrációban (utóbbit nem szelektáláshoz, hanem a növényi táptalajok bakteriális fertőzésének visszaszorítása érdekében használtuk). 


\subsubsection{Baktériumok}

A molekuláris klónozási munkák során Escherichia coli (E. coli) XL-1 Blue törzset használtunk (Stratagene). A növényi transzformáláshoz elkészített plazmidokat E. coli S17-1 törzsbe transzformáltuk, ezt követően a baktériumot ampicillines LB folyadékkultúrában növesztettük. Az Agrobacterium tumefaciens GV3101 (pPM90RK) (Rif ${ }^{\mathrm{R}}, \mathrm{Kan}^{\mathrm{R}}$ ) törzsböl (Koncz és mtsai., 1994) YEB tápoldatban neveltünk kultúrát. Utóbbi törzs hivatott arra, hogy a növénybe bejuttassa az idegen DNS darabot (t-DNS). A két elkészült szuszpenzióból egyenlő mennyiségeket (1-1 mL) összekevertünk, majd a keveréket 24 órán keresztül antibiotikumot nem tartalmazó YEB táplemezen neveltük $28{ }^{\circ} \mathrm{C}$-on. A növekedő tenyészetböl rifampicin, karbenicillin és kanamicin tartalmú YEB táplemezre szélesztettünk, majd a rezisztens Agrobacterium telepeket három alkalommal kentük át friss lemezre (passzálás). Az E. coli-tól ily módon megtisztított Agrobacterium-ot használtuk a növények transzformálására. Az Arabidopsis virág-infiltrációs transzformálást a korábban leírtak alapján végeztük (Clough és Bent, 1998). Lemezeinkben a kanamicint biztonsági okokból használjuk, hogy elkerüljük a többi agrobaktérium törzsünkkel történő esetleges befertőződést.

\subsubsection{Növények}

Kísérleteinkhez Arabidopsis thaliana L (Heynh.) uvr8-6 (Favory és mtsai., 2009), uvr8-7 (Favory és mtsai., 2009), hy5-ks50 (Oyama és mtsai., 1997), phot1phot2amiUVR8 (Vandenbussche és mtsai., 2014) mutáns, Wassilewskija (Ws) és Columbia (Col) növényeket használtunk, utóbbi kettőt vad típusú kontrollként. A hy5-1 hátterü ProHY5:HY5-YFP transzgént hordozó vonal korábban elkészült (Oravecz és mtsai., 2006), ezt a vonalat kereszteztük az uvr8-6 mutáns vonallal, így állt elő az uvr8 hátterü ProHY5:HY5-YFP transzgént expresszáló vonal. A transzformált növények magjainak begyüjtése után a rezisztens egyedek szelektálása klaforánnal és higromicinnel kiegészített szelekciós AM táptalajon történt steril körülmények között. A rezisztens egyedeket két hét elteltével földbe ültettük, majd üvegházban neveltük. Konstrukciónként 10-10 vonalat neveltünk, amikből kiválogattuk azokat, amik a transzgénre nézve egygénes mendeli hasadást mutattak. Ezt követően vizsgálatainkat a transzgénre nézve homozigóta egyedeken végeztük. Legalább 3-3 független vonalat vizsgáltunk, az összehasonlítható eredményeket mutattuk be. 


\subsection{Növények nevelése és fénykezelése, kísérletek}

\subsubsection{Csíranövények nevelése és UV-B kezelése}

A magok felületi sterilizálása 30\%-os Domestos oldatban történt, steril vízben négyszeri átmosást követően 72 órás duzzasztáson estek át, sötétben, $4{ }^{\circ} \mathrm{C}$-on (csírázás indukció). Ezt követően a magokat 1⁄2MS1 (MS = Murashige and Skoog, Sigma-Aldrich) táptalajra szélesztettük. A mikroszkópos kísérletekhez a csíranövényeket 12 óra fehér fény $\left(80 \mu \mathrm{mol} \mathrm{m} \mathrm{m}^{-2} \mathrm{~s}^{-1}\right) / 12$ óra sötét ciklusban neveltük $22{ }^{\circ} \mathrm{C}$-on 6 napig, növénynevelö kamrákban (MLR-350, Sanyo, Gallenkamp, Egyesült Királyság), ezután UV-B fénnyel kiegészített folyamatos fehér fény alá tettük őket. A fehér fényt PHILIPS TL-D 18W/33-640 fénycsövek biztosították $\left(10 \mu \mathrm{mol} \mathrm{m}^{-2} \mathrm{~s}^{-1}\right)$. A károsodást nem okozó, alacsony intenzitású UV-B fényt PHILIPS ULTRAVIOLET-B TL20W/01RS

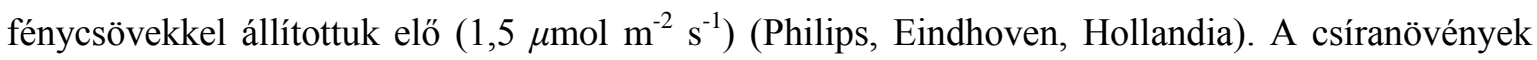
UV-B kezeléséhez $3 \mathrm{~mm}$ vastag WG filtereket használtunk (Schott, Mainz, Németország), a korábban leírtak szerint (Ulm és mtsai., 2004). Ezek a filterek úgynevezett alulvágó (cut-off) filterek. Az UV-B kezelt csíranövényeket (+UV-B) WG305 filterrel (kiszüri az UV-C tartományt, de átengedi az UV-B jelentős részét), míg a nem UV-B kezelt kontroll növényeket (-UB-V) WG385 (a teljes UV-B tartományt kiszürő) filterrel takartuk le, ahogy azt korábban leírták (Oravecz és mtsai., 2006; Favory és mtsai., 2009; Rizzini és mtsai., 2011). Az UV-B fényt egy CX-312 szenzorral felszerelt VLX-3W UV fénymérővel (Vilber Lourmat, Eberhardzell, Németország), a látható fényt egy LI-250 Light Meter (Li-Cor, Lincoln, NE, Egyesült Államok) fényintenzitás mérővel mértük. A hipokotil- és sziklevél felületmérésekhez a csíranövényeket 3 napig növénynevelő kamrában tartottuk, mielőtt megkapták az UV-B fénnyel kiegészített folyamatos fehér fényes kezelést 4-, vagy 5 napon keresztül.

\subsubsection{Felnőtt növények nevelése és UV-B kezelése}

Az Arabidopsis magokat virágföldre szórást követően $4{ }^{\circ} \mathrm{C}$-on tartottuk 4 napig, ezt követően növénynevelő kamrában neveltük (Grobank, CLF Plant Climatics, Wertingen, Németország) rövidnappalos körülmények között (8 óra fény/16 óra sötét) fehér fényben $\left(120 \mu \mathrm{molm}^{-2} \mathrm{~s}^{-1}\right)$, vagy UV-B fénnyel kiegészített fehér fényben (kísérleteknél jelölt intenzitáson), $22{ }^{\circ} \mathrm{C}$-on. A látható fényt egy LI-250 Light Meter (Li-Cor, Lincoln, NE, Egyesült Államok) fénymérővel mértük. A kamrában a fénykörülmények beállítása Aphalo és munkatársai (2012) által leírtak alapján történt, az alkalmazott fény teljes spektrumát egy QE65000 spektrométerrel (Ocean

Optics, Dunedin, FL, Egyesült Államok) mértük (5. ábra). Fehér fluoreszcens fénycsöveket (L18W, Osram, München, Németország) és a csíranövény fénykezelésénél is használt UV-B fénycsöveket használtuk (TL20W/01RS, Philips). A kezeléseinkhez használt UV-B intenzitásokat 
úgy választottuk meg, hogy azok hasonlóak legyenek a Szegeden, egy átlagos nyári napon, 11:00 és 13:00 között mért természetes értékekhez (7-15 $\left.\mu \mathrm{mol} \mathrm{m} \mathrm{m}^{-2} \mathrm{~s}^{-1}\right)$. Az UV-B sugárzást egy CX-312 szenzorral felszerelt VLX-3W UV fénymérővel (Vilber Lourmat, Eberhardzell, Németország) mértük. A tőlevélrózsa átmérőt héthetes növényeken mértük, az analízishez ImageJ (NIH Bethesda, MD, Egyesült Államok) képelemző szoftvert használtunk.

A szárelhajlás, flavonoid akkumuláció és HY5/HYH felhalmozódás szárban történő méréséhez a növényeket növénynevelő kamrában neveltük $22{ }^{\circ} \mathrm{C}$-on, hosszú nappalos fénykörülmények között (16 óra $65 \mu \mathrm{mol} \mathrm{\textrm {m } ^ { - 2 }} \mathrm{s}^{-1}$ intenzitású fehér fény/8 óra sötét). Hozzávetőlegesen 5-6 hetes növényeket válogattunk a kísérleteinkhez, amiket együtt neveltünk és megfelelő hosszúságú (minimum $5 \mathrm{~cm}$ ) szárral rendelkeztek. A kiválasztott növényeket egyoldali, gyenge UV-B kezelésnek tettük ki: a 311 nm UV-B sugárzást egy TL01 lámpa biztosította (Philips), a kibocsátott sugárzást cellulóz-acetát film segítségével szürtük, hogy a $295 \mathrm{~nm}$ alatti sugarakat távol tartsuk a növényektöl. Így $1,4 \mu \mathrm{mol} \mathrm{m} \mathrm{m}^{-2}$ intenzitású UV-B és $2,5 \mu \mathrm{mol} \mathrm{m} \mathrm{m}^{-2} \mathrm{~s}^{-1}$ intenzitású fehér fény keverékét kaptuk. A fénymérést egy UV-B detektorral felszerelt PMA2100 fénymérővel (SOLAR LIGHT CO. Glenside, PA, Egyesült Államok) és egy SKP200 fénymérővel (Skye Instruments, Powys, Egyesült Királyság) végeztük.
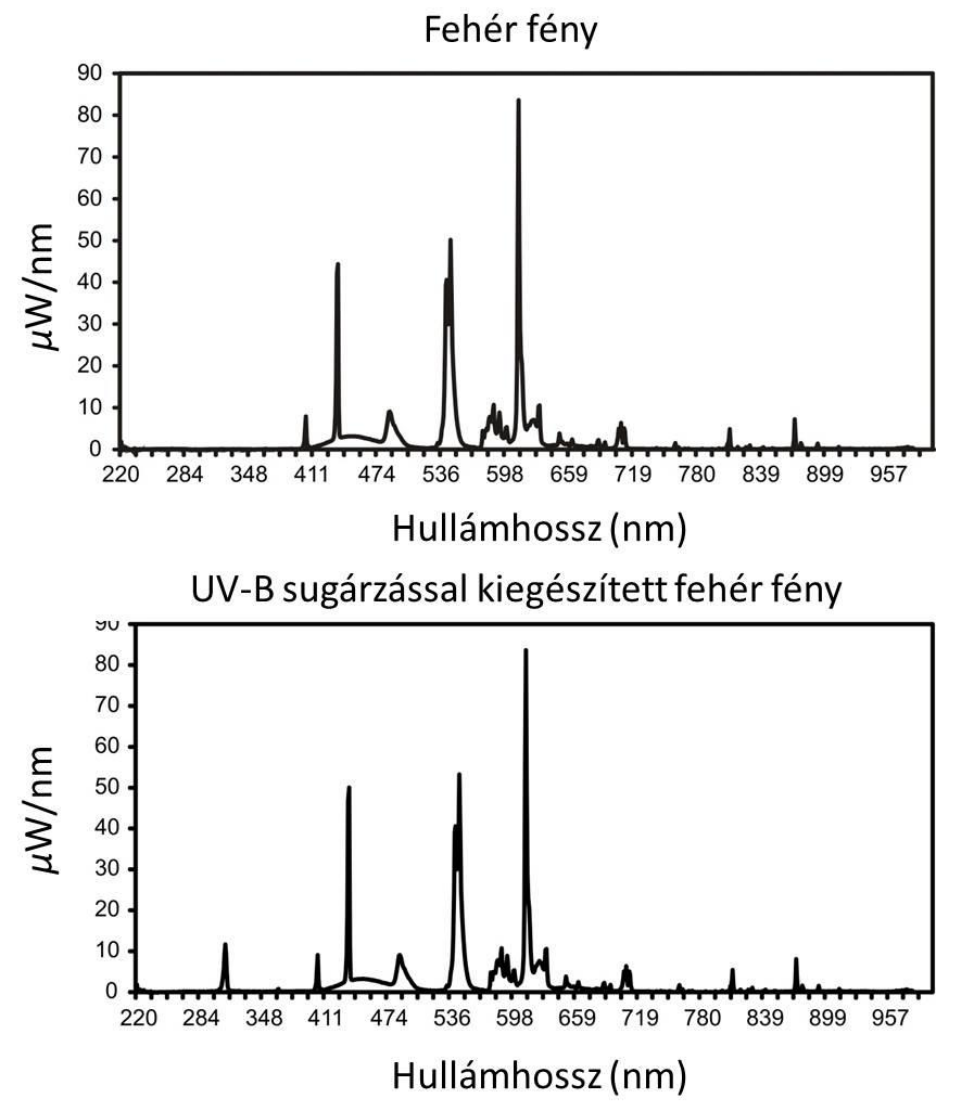

5. ábra: A növénynevelő kamrában használt fehér, illetve UV-B-vel kiegészített fehér fény teljes spektruma 


\subsubsection{Hipokotil hossz és sziklevél felület meghatározása}

Kísérleteinkben legalább 40 csíranövényt és 100 sziklevelet mértünk le vonalanként és kezelésenként. Minden vizsgálatban az UV-B-vel kezelt/nem kezelt hipokotil hossz, vagy sziklevél felület értékek arányát számoltuk. Minden kísérletet legalább háromszor ismételtünk. A csíranövényekről készített képeken a hipokotilok hosszát, valamint a sziklevelek felületét ImageJ (NIH) képelemző szoftver segítségével mértük le, a kapott értékeket átlagolva, az átlagok standard hibáját feltüntetve ábrázoltuk.

\subsubsection{UV-B irányba történő szárelhajlás vizsgálata felnőtt növényen}

Az UV-B irányba történő szárelhajlás vizsgálatát a 4.2.2. fejezetben leírt módon nevelt felnőtt növényeken végeztük. A kiválasztott egyedeket fekete falú nevelőszobába tettük, ahol egyoldali UV-B sugárzást alkalmaztunk: a 311 nm UV-B sugárzást egy TL01 lámpa biztosította (Philips), a kibocsátott sugárzást cellulóz-acetát film segítségével szürtük, hogy a $295 \mathrm{~nm}$ alatti sugarakat távol tartsuk a növényektől. Így $1,4 \mu \mathrm{mol} \mathrm{m} \mathrm{m}^{-2} \mathrm{~s}^{-1}$ intenzitású UV-B és $2,5 \mu \mathrm{mol} \mathrm{m} \mathrm{m}^{-2} \mathrm{~s}^{-1}$ intenzitású fehér fény keverékét kaptuk. A fénymérést egy UV-B detektorral felszerelt PMA2100 fénymérővel (SOLAR LIGHT CO. Glenside) és egy SKP200 fénymérővel (Skye Instruments) végeztük. Az egyoldali UV-B kezelés alatt a kiválasztott növényekről az éjszaka folyamán 15 percenként egy webkamerás, automatizált képrögzítő rendszer - infravörös filter nélküli CCD kamera (Guillemot, La Gacilly, Franciaország), Active WebCam v.4 software (PY Software, Etobicoke, Kanada) - segítségével készítettünk a fény beérkezési síkjára merőleges képeket a növényekről (Vandenbussche és mtsai., 2010). Az elkészült képeket ImageJ (NIH) képelemző szoftver segítségével elemeztük, a mért értékek átlagát ábrázoltuk.

\subsubsection{Klorofilltartalom meghatározása}

A klorofilltartalom mérésének menete a korábban leírtak alapján történt (Porra és mtsai., 1989). Mintánként 10-10 csíranövényt 1,5 mL-es reakciócsőbe gyüjtöttünk. Nedves tömegük lemérése után 1-1 mL N,N-dimetilformamidot (Sigma-Aldrich) mértünk a növényi anyagra. A mintákat 24 órán keresztül szobahőmérsékleten, sötétben tartottuk, miközben időnként összeráztuk őket. Ezután a mintákat lecentrifugáltuk, a tiszta felülúszó abszorbanciáját spektrofotométerrel (Shimadzu UV-160A, Kiotó, Japán) mértük 664 nm-en. A klorofill mennyiségét ebből az értékből számítottuk ki, korábban leírtak alapján (Inskeep és Bloom, 1985) és az adott minta nedves tömegéhez arányosítva, a kontrollhoz viszonyítva ábrázoltuk. 


\subsection{Mikroszkópos technikák}

\subsubsection{Metszetek készítése felnőtt növények virágzati szárából}

Mikroszkópos vizsgálatokhoz a felnőtt növények virágzati szárának felső harmadából származó metszeteket készítettünk. A vizsgálni kívánt szárrészt (1-1,5 cm) orvosi szikével vágtuk ki a szár felső harmadából, majd a szárdarabokat vágott 1,5 mL-es reakciócsövekben függőlegesen, 7\%-os, alacsony olvadáspontú agarózba (Sigma-Aldrich) dermesztettük. Az agarózba ágyazott szárdarabokból vibratóm (Thermo scientific HM560, Waltham, MA, Egyesült Államok) segítségével metszeteket készítettünk, amiket üveg tárgylemezekre gyüjtöttünk (metszetvastagság: $100 \mu \mathrm{m}$, frekvencia: $120 \mathrm{~Hz}$, amplitúdó: 0,9 $\mu \mathrm{m}$ ). A metszeteket mikroszkóppal vizsgáltuk a 4.3.2. és a 4.3.3. fejezetekben leírtak szerint.

\subsubsection{Konfokális lézer-pásztázó mikroszkópia}

A csíranövényeken végzett kísérletek során használt konfokális lézer-pásztázó mikroszkóp (CLSM) beállításai és a magi fluoreszcencia mérésre vonatkozó részletes információkat Kirchenbauer és munkatársai (2016) írták le korábban. CLMS vizsgálatainkhoz Leica SP5 konfokális lézer-pásztázó mikroszkópot (Leica, Wetzlar, Németország) használtunk. A GFP-t a 488 nm-en, az YFP-t 514 nm-en gerjesztettük, a jelet érzékelő detektorok beállítása 496-518 nm (GFP), illetve 545-582 nm (YFP) volt. Ezekkel a beállitásokkal az YFP-ből és a GFP-ből származó jelek jól elkülöníthetőek (6. ábra). A mikroszkóp beállításai, illetve a képfeldolgozás során alkalmazott fényerő és a kontraszt értékek az összetartozó képek esetében ugyanazok voltak, így azok egymással összehasonlíthatóak.

uvr8-6 háttérben ML1:YFP-UVR8

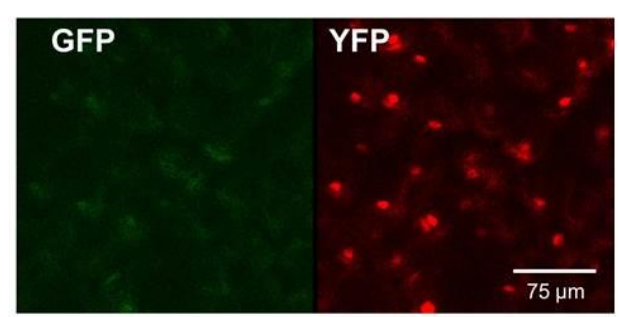

Col háttérben HY5:GFP-GUS-NLS

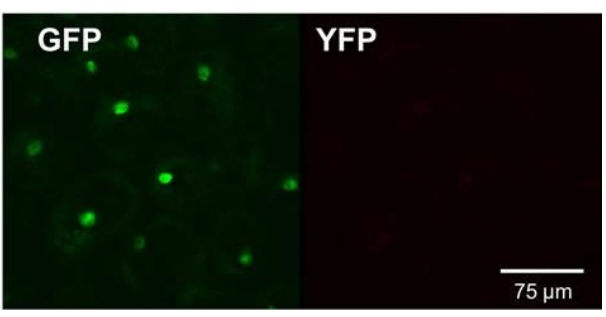

\section{6. ábra: YFP és GFP jelek detektálása}

Az YFP és GFP jelek elkülönítését bemutató mikroszkópos felvételek. A mikroszkóp beállításai fentebb találhatóak. 
Felnőtt növények esetében a szár elhajlásának vizsgálatakor alkalmazott egyoldali UV-B kezelést használtuk különböző időtartamig (eredményeknél jelölve), ezt követően a szár árnyékos oldalát kalkofluór (Calcofluor fluorescent brightener 28, Sigma-Aldrich) oldattal ecseteltük, hogy a vibratómmal készített metszetek orientációja a tárgylemezen is követhető maradjon. A metszetekben található GFP jeleket CLSM mikroszkóppal figyeltük meg (Nikon, EZ C1, Tokyo, Japán), mindegyik képet azonos beállításokkal készítettük el. A jelintenzitás mérését a megvilágított oldalon végeztük, ezzel beállítva a maximális intenzitást, elkerülve a jelek szaturálását. Az elkészült képeket a mikroszkóp saját szoftverével értékeltük ki (Advanced Research analízis szoftver: Nikon, EZ C1, Tokyo, Japán). A megvilágított és árnyékos oldalon is 10-10 sejtmagot mértünk le, a mérés adatait Microsoft ${ }^{\circledR}$ Excel-ben (Redmond, WA, Egyesült Államok) tovább szerkesztettük, a kapott értékek átlagát ábrázoltuk. A kalkofluor ecsetelés helyének meghatározásához a mikroszkópon DAPI-festés (4',6-Diamidin-2'-fenilindol dihidroklorid) detektálására alkalmas beállításokat alkalmaztunk. Minden kísérlethez legalább 5-5 növényt használtunk vonalanként. A mikroszkóp beállításokat a korábban leírtak alapján végeztük (Vandenbussche és Van Der Straeten, 2014).

\subsubsection{Flavonoid detektálás}

Csíranövényeken végzett kísérletek során a magok csíráztatása a fentebb leírtak alapján történt. A csíranövényeket 2 napig 12 óra fehér fény/12 óra sötét körülmények között neveltük, majd 4 napig 1,5 $\mu \mathrm{mol} \mathrm{m} \mathrm{m}^{-2} \mathrm{~s}^{-1}$ intenzitású fehér fény alatt nőttek, ami $1,5 \mu \mathrm{mol} \mathrm{m} \mathrm{m}^{-2} \mathrm{~s}^{-1} \mathrm{UV}-\mathrm{B}$ fénnyel volt kiegészítve. Az UV-B kezelt csíranövényeket (+UV-B) WG305 filterrel, míg a nem UV-B kezelt negatív kontroll növényeket (-UB-V) WG385 filterrel takartuk le. A mikroszkópos vizsgálatot megelözően a csíranövényeket $0,1 \%(w / v)$ DPBA (diphenylboric acid 2-aminoethyl ester, Sigma-Aldrich) tartalmú, 0,15 $\mathrm{M} \mathrm{KH}_{2} \mathrm{PO}_{4}$ (Molar Chemicals) és 0,15 $\mathrm{M} \mathrm{Na}_{2} \mathrm{HPO}_{4}$ (Molar Chemicals) összetételü foszfát pufferben ( $\mathrm{pH}=6,8)$ inkubáltuk sötétben, 15 percig. Ezután a DPBA oldatot eltávolítottuk, a csíranövényeket friss foszfát pufferrel kétszer átmostuk. A pásztázó mikroszkóppal (Leica S5P, Németország) a DPBA-flavonoid komplexre jellemző fluoreszcenciát detektáltuk (488 nm lézer; pinhole: $200 \mu \mathrm{m}$; spektrális emisszió detektor: 501-601 nm).

A felnőtt növényeket a már korábban leírtak alapján neveltük, majd különböző idejü (eredményeknél jelölt), egyoldali UV-B sugárzásnak tettük ki. A szárakon az árnyékos oldalt laborfilc segítségével megjelöltük, majd a metszetek készítésekor ezt figyelembe véve, a szármetszetek morfológiája alapján tudtuk pozícionálni a bemutatásra szánt, jelöletlen szakaszból készített metszeteket. Ezt követően a szárak felső harmadából 3-4 cm-es darabokat vágtunk, majd ezeket egy éjszakán át 96\%-os etanolban áztattuk a klorofill eltávolítása érdekében. Másnap az etanolt DPBA oldatra -0,00375\% (w/v) Triton X100 (Serva, Heilderberg, Németország), 0,25\% (w/v) DPBA-, vagy steril vízre (kontroll) cseréltük, majd 2 órányi áztatást követően vibratóm 
készülékkel a korábban leírt módon metszeteket készítettünk, ezeket tárgylemezre gyüjtöttük. A flavonoidok felhalmozódását epifluoreszcens mikroszkóppal vizsgáltuk (Zeiss Axiovert 200M, Oberkochen, Németország), korábbiakban leírt beállításokat használtunk: 365-395 nm-es gerjesztő fény, $420 \mathrm{~nm}$ long pass emission filter (Stracke és mtsai., 2010).

\subsection{Molekuláris biológiai módszerek}

\subsubsection{Molekuláris klónozás}

A restrikciós emésztésekhez használt enzimek a Thermo Fisher Scientific-tôl származtak, felhasználásuk során követtük a gyártó utasításait. A megemésztett DNS fragmentek tisztítását, összeligálásukat, valamint a baktériumok transzformálást és a szelektálási lépéseket a Sambrook és munkatársai (2001) által leírtak szerint végeztük. Az YFP és az UVR8 kódoló régiókat a pPCV812es plazmidba $\left(\mathrm{Amp}^{\mathrm{R}}\right.$ ) klónoztuk (Bauer és mtsai., 2004), SmaI-EcoRI és EcoRI-ScaI fragmentek formájában. A MERISTEMLAYER 1 (ProML1), SUCROSE-PROTON SYMPORTER 2 (ProSUC2) és a CHLOROPHYLL A/B BINDING PROTEIN 3 (ProCAB3) promóter fragmentek klónozását a korábban leírtak alapján végeztük (Kirchenbauer és mtsai., 2016), a ProUVR8 klónozása egy 2569 bázispáros SalI-BamHI DNS fragmentként történt. A $\beta$-glüuronidáz (GUS) kódoló régiója SmaIXhoI (Ádám és mtsai., 1995), a GFP egy XhoI-ClaI, az NLS egy ClaI-SacI fragmentként (Wolf és mtsai., 2011) került a pPCVB812 bináris vektorba (Bauer és mtsai., 2004), így jött létre a GUS-GFP-NLS pPCVB vektor. Ezt HindIII és SmaI restrikciós enzimekkel emésztettük, a ProHY5et (Oravecz és mtsai., 2006) HindIII-StuI fragmentként klónoztuk, ezzel helyettesítve a $35 S$ promótert (Pro35S). A ProELIP2 (EARLY LIGHT INDUCED PROTEIN 2) és a ProPRR9 (PSEUDO-RESPONSE REGULATOR 9) promóterek klónozása 2772 bp (BamHI-XbaI), valamint 1324bp (BamHI-SmaI) fragmentekként történt. A ProHY5:HY5-GFP klónt korábban készítettük el (Kirchenbauer és mtsai., 2016).

\subsubsection{Növényi fehérjekivonatok készítése}

Kísérleteink során mintánként 100-150 mg növényi anyagot szedtünk 1,5 mL-es reakciócsövekbe. A mintákat folyékony nitrogénben fagyasztottuk le, majd $95{ }^{\circ} \mathrm{C}$-ra előmelegített feltáró puffert -50 mM Tris-HCl (Molar Chemicals) (pH=6,8), $4 \mathrm{M}$ urea (Sigma-Aldrich), 3\% (w/v) SDS (Molar Chemicals), 0,1 M ditiotreitol (Sigma-Aldrich), 10\% glicerin (SigmaAldrich), 0,4 g/L brómfenolkék (Serva)- mértünk az adott mintára. Közvetlenül ezután speciális fúróheggyel történt a csőben lévő minták feltárása eldörzsöléssel, $80 \mathrm{mp} 95{ }^{\circ} \mathrm{C}$-os melegítést követően újabb dörzsölés, majd 2 perc $95{ }^{\circ} \mathrm{C}$-os melegítés következett. A feltárást minden egyes mintával egyenként végeztük el. A feltárt mintákban a törmeléket 5 perc centrifugálással 
ülepítettük, a felülúszót új csövekbe gyüjtöttük. Az így nyert fehérjekivonatok további kezelés nélkül felvihetőek SDS-poliakrilamid gélre.

\subsubsection{Fehérjeszint meghatározás Western blot módszerrel}

A fehérjék elválasztásához 10\%-os SDS-poliakrilamid denaturáló gélt alkalmaztunk, a futtatás Tris/glicin/SDS futtató pufferben történt: $25 \mathrm{mM}$ Tris (Molar Chemicals), $192 \mathrm{mM}$ glicin (Sigma-Aldrich), 0,1\% (w/v) SDS (Molar Chemicals). Mintánként 20-20 $\mu \mathrm{g}$ összfehérjét futtattunk meg. Az elválasztást követően a gélt néhány percig mosópufferben -0,05 M Tris/ $\mathrm{HCl}$ (Molar Chemicals) (pH=7,4), 0,2 M NaCl (Molar Chemicals), 0,05\% Tween $^{\circledR} 20$ (Sigma-Aldrich)áztattuk, amíg metanollal equilibráltuk az Immobilon ${ }^{\circledR}$-P PVDF (polivinilidén-difluorid) mủanyag membránt (Merck Millipore, Darmstadt, Németország), amire a fehérjék átvitelét végeztük. A gélből a fehérjéket elektroblot készülékkel (BioRad, Hercules, CA, Egyesült Államok) vittük át a PVDF membránra $(100 \mathrm{~V}, 2 \mathrm{~h})$. Az átvitel végén a membránt egy éjszakán keresztül $4^{\circ} \mathrm{C}$-on, blokkoló pufferben áztattuk: 2,5\% (w/v) tejpor (zsírmentes tejpor, élelmiszerboltból), 0,1 M Tris- $\mathrm{HCl}$ (Molar Chemicals) (pH=7,4), 0,2 M NaCl (Molar Chemicals), 0,05\% Tween ${ }^{\circledR} 20$ (SigmaAldrich). Másnap a membránt mosópufferben egyszer átöblítettük, majd 1,5 órán keresztül mosópufferben oldott anti-UVR8 ellenanyaggal (Prof. Roman Ulm ajándéka), vagy anti-aktin ellenanyaggal (Sigma-Aldrich) mostuk szobahömérsékleten. Ezt a lépést 3x10 perc mosás követte mosópufferrel. Ezután mosópufferbe oldott torma peroxidáz (HRP) kapcsolt nyúl-IgG elleni (Dako/Agilent, Santa Clara, CA, Egyesült Államok) (anti-UVR8 elsődleges ellenanyag esetén), vagy egér-IgG elleni (Invitrogen, Carlsbad, CA, Egyesült Államok) (anti-aktin esetén) másodlagos ellenanyaggal mostuk a membránokat 1,5 órán keresztül. További 3x10 perces mosópufferes mosást követöen a leitatott membránt $30 \mathrm{mp}$-ig áztattuk Millipore Immobilon Western Chemiluminescent HRP Substrate Peroxidáz és Luminol reagensek 1:1 arányú oldatában, majd CCD kamera (Hamamatsu C4742-98, Hamamatsu, Japán) segítségével detektáltuk a kemilumineszcens reakcióból származó jeleket. A fehérjekivonatok elkészítését és a Western blot kísérleteket háromszor ismételtük, az eredményeket reprezentáló képeket mutatom be. A kapott jelek intenzitását ImageJ (NIH) képelemző szoftver segítségével számszerüsítettük.

\subsubsection{A transzkripciós szintek meghatározása}

Az össz-RNS kivonat készítése, a cDNS szintézis és a kvantitatív RT-PCR analízis Fehér és munkatársai (2011) leírása alapján történtek. Csíranövények esetében adott fénykezelést követően teljes csíranövényekből készítettünk össz-RNS mintát.

Felnőtt növények esetében végzett egyoldali UV-B sugárzást követő HY5 és $H Y H$ expressziós mintázatot vizsgáló kísérletünkben hosszában félbevágott szárak 1,5-2 cm hosszúságú 
darabjait gyüjtöttük reakciócsövekbe, külön a megvilágított és az árnyékos oldali feleket, mintánként legalább három növényröl. A feltárást minden esetben a folyékony nitrogénben lefagyasztott minták rázatásos homogenizálásával végeztük Retsch ${ }^{\circledR}$ MM 301 (Retsch, Budapest, Magyarország) homogenizátor segítségével.

Feltárást követően $1 \mu \mathrm{g}$ RNS-ből cDNS-t készítettünk cDNS szintézis kittel, random hexamer primereket használva, a gyártó utasításainak megfelelően (Fisher Scientific RevertAid ${ }^{\mathrm{TM}}$ First-Strand cDNA Synthesis Kit). Az mRNS szinteket valós időben mért PCR-rel határoztuk meg ABI PRISM ${ }^{\circledR} 7300$ (Applied Biosystems, Foster City, CA, Egyesült Államok) gépet használva, POWER SYBR ${ }^{\circledR}$ Green PCR Master Mix (Applied Biosystems) alkalmazásával. Minden kísérletnél készült egy, a mintákból keverékként elöállított cDNS hígítási sor, mely 1-, 10-, 100-, 1000-szeres hígítási pontokat tartalmazott. A hígítási sor tagjaiban megmértük az adott mRNS-ek szintjét, majd az egyes primerpárokkal kapott értékekre egy egyenest illesztettünk, aminek meghatároztuk az egyenletét. A vizsgálni kívánt mintákban az mRNS szintet ez alapján számítottuk ki. A kapott értékeket a minták TUB2 és TUB3 (tubulin) össz-mRNS szintjéhez vonatkoztatva adtuk meg. Minden mérést háromszor ismételtünk meg. A PCR körülményeit a következők szerint állítottuk be: $94{ }^{\circ} \mathrm{C} 2,5$ perc, $40 x\left(95{ }^{\circ} \mathrm{C} 15 \mathrm{mp}, 60{ }^{\circ} \mathrm{C} 1\right.$ perc), $95^{\circ} \mathrm{C} 15 \mathrm{mp}, 60^{\circ} \mathrm{C} 15 \mathrm{mp}$. A sokszorozáshoz használt primerek $(0,3 \mu \mathrm{M})$ listája az alábbi táblázatban olvasható:

\begin{tabular}{|c|c|c|}
\hline Gén neve & Forward primer $\left(5^{\prime} \rightarrow 3^{\prime}\right)$ & Reverse primer $\left(3^{\prime} \rightarrow 5^{\prime}\right)$ \\
\hline ELIP2 (At4g14690) & CAGTTAGCAAGCCTAAGGTG & AATCCAACCATTGCTAGTCTC \\
\hline PRR9 (At2g46790) & ACTCAACTCGTCAAATCATCAC & TCTCCTTTAGAACCTCCCAC \\
\hline HY5 (At5g11260) & CAGGCGACTGTCGGAGAAAGTCAAAGG & TCAACAACCTCTTCAGCCGCTTGTTCTC \\
\hline HYH (At3g17609) & GCCTCAAGAGATTATTGAGGA & CTCTTGATTCCAAATCACTCAC \\
\hline CHS (At5g 13930) & TGAGAACCATGTGCTTCAGGCGGAG & TGTCGACTTGTCGCACATGCGCT \\
\hline TUB2/TUB3 (At5g62690/At5g62700) & CCAGCTTTGGTGATTTGAAC & CAAGCTTTCGGAGGTCAGAG \\
\hline
\end{tabular}

1. táblázat: a transzkripciós szintek meghatározásához használt primerek jegyzéke 


\section{EREDMÉNYEK}

\subsection{Az UVR8 felhalmozódása különböző szövetekben}

\subsubsection{A ProUVR8:YFP-UVR8 transzgén expressziójának helye Arabidopsis növényben}

Mivel vizsgálatainkban az UVR8 szövettípusoktól függő funkcióira szerettünk volna fókuszálni, ezért első lépésként fel kellett derítenünk, hogy pontosan milyen szövetekben található UVR8 a növényben. Elöállítottunk olyan transzgenikus növényi vonalakat, melyek az YFP-UVR8 fúziós fehérjét az UVR8 gén saját promóterének irányítása alatt termelik uvr8 mutáns háttérben. Mivel mindegyik vonalunk alacsony szinten termelte az YFP-UVR8 fehérjét, kísérleteinkhez kiválasztottuk a legmagasabb szinten expresszáló vonalat (későbbiekben: ProUVR8 vonal). A ProUVR8 növények szöveteiben és a (későbbiekben bemutatásra kerülö, YFP-UVR8-at szövetspecifikusan termelő) többi vonalunk különböző szöveteiben mérhető YFP-UVR8 mennyiségek jól összehasonlíthatónak bizonyultak. A növények vizsgálata a csíranövények esetében a sziklevél és a hipokotil epidermiszére, a sziklevelek (és felnőtt növények leveleinek) mezofill szöveteire, a hipokotil szubepidermális sejtjeire (felnőtt növény szárában a kortexre), valamint a szállítószövetekre vonatkozott. A vizsgált csíranövényekben az YFP-UVR8 fehérjét az epidermiszben, és bár alacsonyabb szinten, de a mezofill/szubepidermális sejtekben is ki tudtuk mutatni CLSM-mel, a sziklevelekben és a hipokotilban egyaránt (7. ábra A-C, 8. ábra A, B). A szállítószövetekben YFP-UVR8-at nem tudtunk detektálni (7. ábra A-C, 8. ábra C).

Felnőtt növény szárában szintén megtalálható az YFP-UVR8 az epidermiszben, valamint a szár kortexében (9. ábra). Érdemes azonban megjegyezni, hogy a használt transzgenikus vonalunkban kifejeztetett YFP-UVR8 fehérje mennyisége megközelítőleg csak 10\%-a volt a vad típusú növényben megtalálható endogén UVR8 fehérje szintjének (10. ábra A) és nem sikerült azonosítani ennél magasabb szinten expresszáló ProUVR8:YFP-UVR8 transzgenikus vonalat. Ennek fényében nem zárhatjuk ki a lehetőségét annak, hogy a vad típusú növények szállítószöveteiben is megtalálható az UVR8 fotoreceptor. 

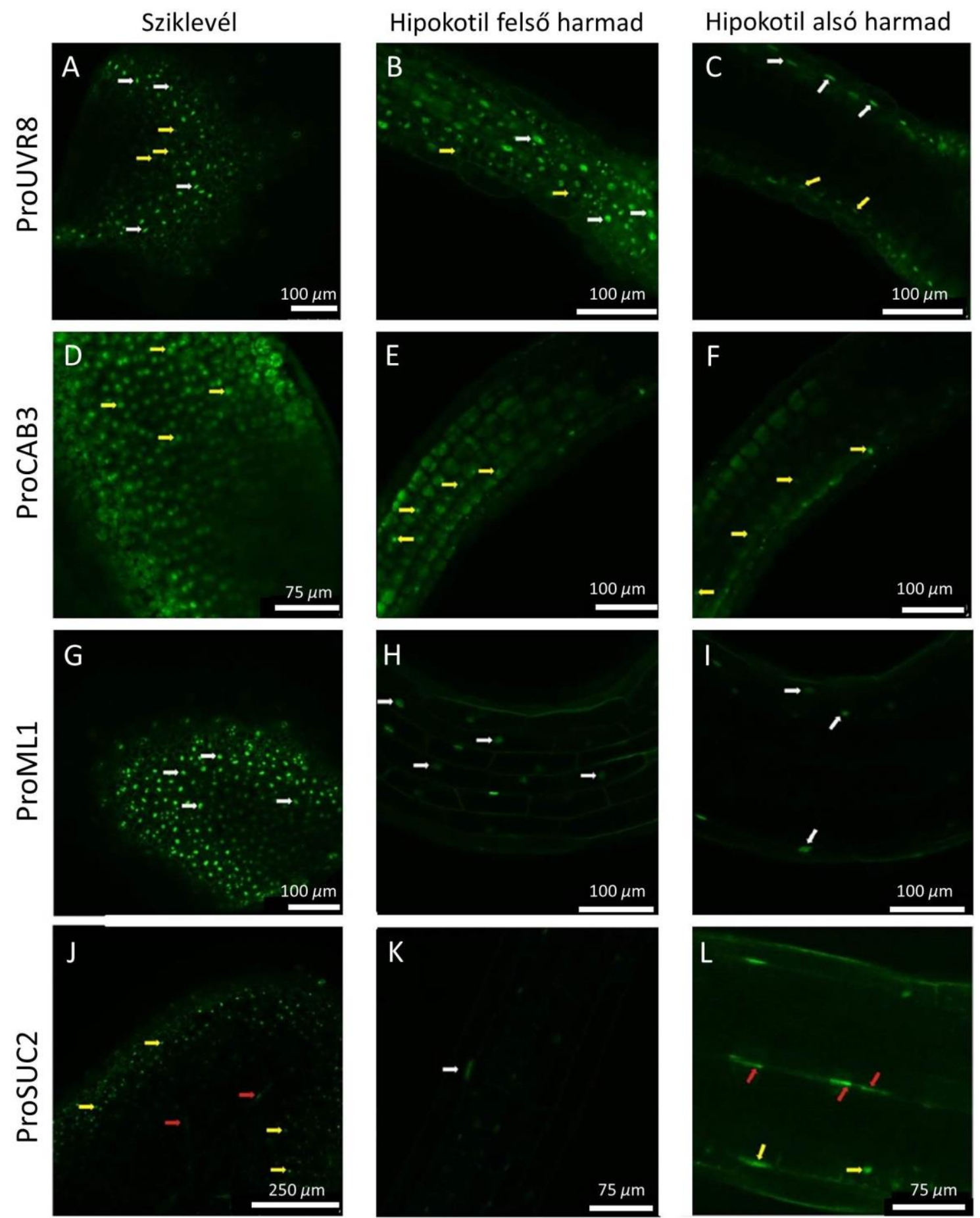

7. ábra: Az YFP-UVR8 fúziós fehérje kimutatása a csíranövény sziklevelében és hipokotiljában CLSM segítségével

A szövetspecifikusan YFP-UVR8-at termelő transzgenikus hétnapos csíranövényekben detektáltuk CLSMmel az YFP-UVR8-ból származó YFP jeleket, különböző szövetekre fókuszálva:

Első oszlop: (A, D, G, J) Sziklevél.

Második oszlop (B, E, H, K) Hipokotil (felső része), fókuszsík az epidermisz/epidermisz alatti szövetrész határán.

Harmadik oszlop: (C, F, I, L) Hipokotil (felső része), fókuszsík az epidermisz alatti/szállítószövetek rétegében.

Fehér nyilak: néhány kiválasztott sejtmag az epidermiszben, sárga nyilak: sejtmagok a mezofill/szubepidermális rétegben, piros nyilak: sejtmagok a szállítószövetekben. 

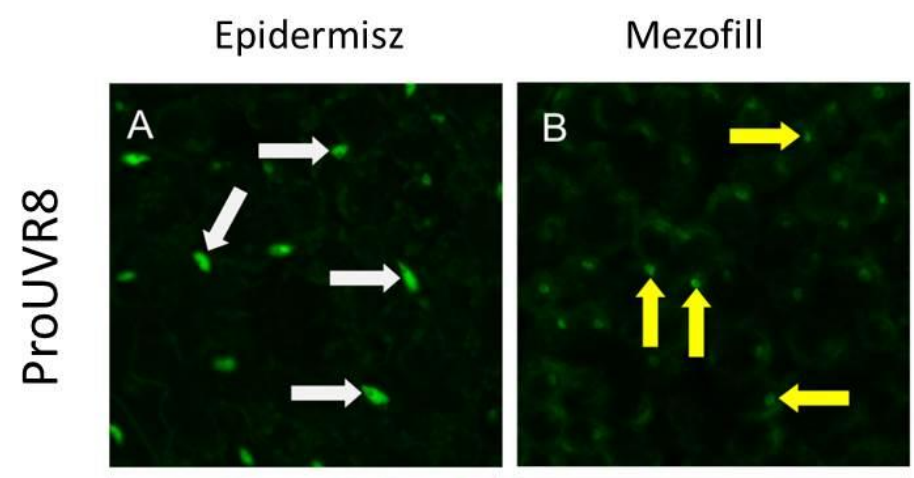

\section{Szállítószövetek}
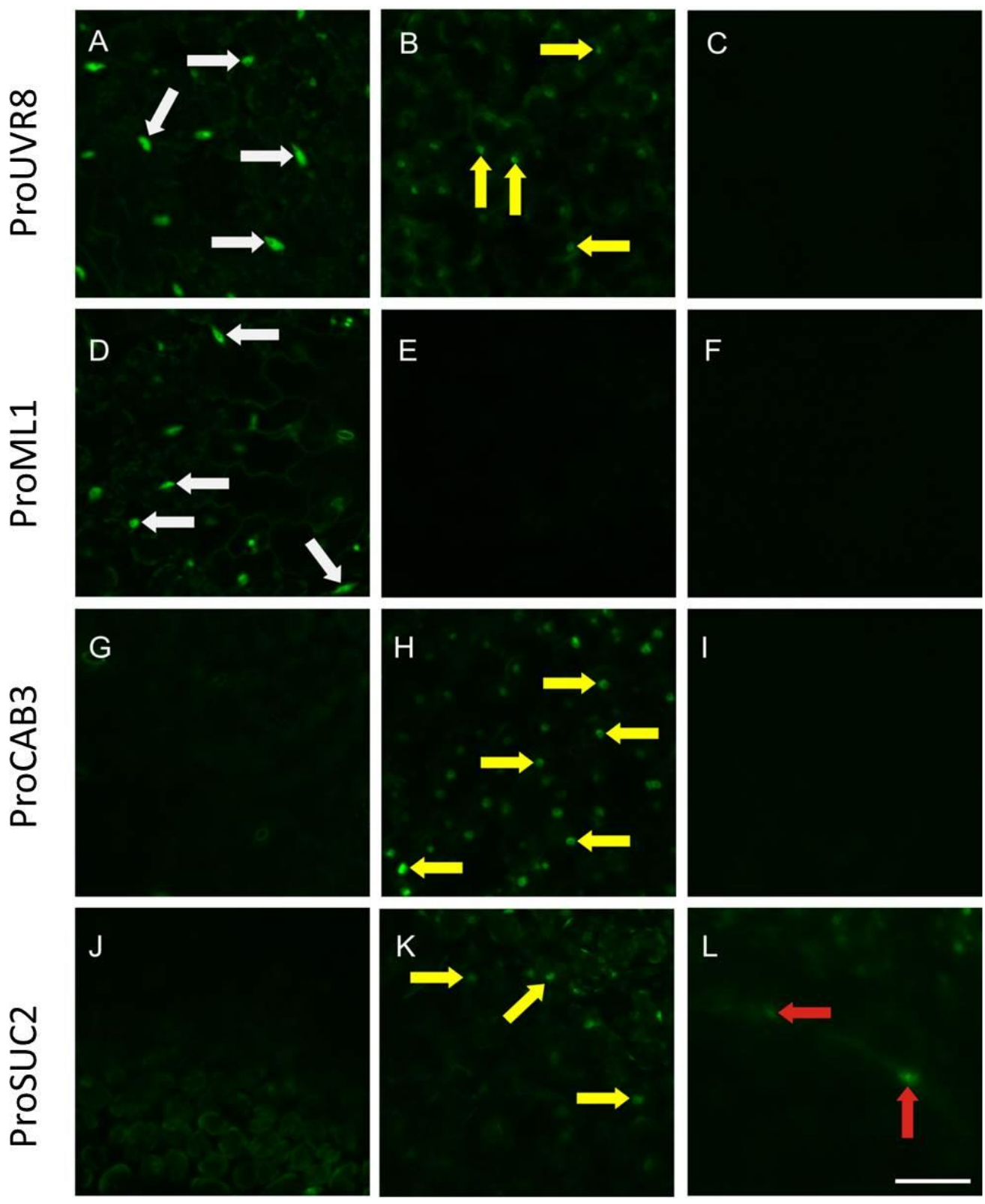

\section{8. ábra: Az YFP-UVR8 fúziós fehérje szövetspecifikus kifejeződése transzgenikus csíranövények sziklevelében}

Az YFP-UVR8 fehérje elhelyezkedését CLSM-el vizsgáltuk az UV-B sugárzással kiegészített fehér fényben nevelt hétnapos transzgenikus $u v r 8$ mutáns növények szikleveleiben. A különböző transzgenikus vonalakban termelödő YFP-UVR8 mennyiségek összehasonlíthatósága érdekében az egyes szövetekben készült képekhez ugyanazokat a beállításokat alkalmaztuk. A ProUVR8 (A, B, C), ProML1 (D, E, F), ProCAB3 (G, $\mathbf{H}, \mathbf{I})$ és ProSUC2 (J, K, L) transzgenikus csíranövények epidermiszét (A, D, G, J), mezofill sejtjeit (B, E, $\mathbf{H}, \mathbf{K})$ és szállítószöveti részeit $(\mathbf{C}, \mathbf{F}, \mathbf{I}, \mathbf{L})$ vizsgáltuk. A fehér nyilak az epidermisz rétegben kiválasztott sejtmagokat, a sárga nyilak a mezofill rétegben kiválasztott sejtmagokat, míg a piros nyilak a szállítószöveti sejtek sejtmagjait jelölik. A méret vonal $50 \mu \mathrm{m}$-t mutat. 


\subsubsection{Az YFP-UVR8 fehérjét különböző szövetekben kifejező transzgenikus növényi vonalak jellemzése}

Annak érdekében, hogy vizsgálni tudjuk az egyes szövetekben található UVR8 fehérje funkcióit, olyan transzgenikus növényi vonalakat is elöállítottunk, melyek $u v r 8$ mutáns háttérben, ProML1, ProSUC2, vagy ProCAB3 promóter irányításával termelik az YFP-UVR8 fehérjét (későbbiekben ProML1, ProSUC2, ProCAB3 néven hivatkozok az adott növényi vonalakra). Ezeket a promótereket korábban már számos alkalommal használták arra, hogy a vizsgált fehérjét specifikusan, bizonyos sejtekben termeltessék: a MERISTEM LAYER 1 promóter (ProML1) az epidermiszben, a CHLOROPHYLL A/B BINDING PROTEIN 3 promóter (ProCAB3) a mezofill/kortex szövetekben, a SUCROSE-PROTON SYMPORTER 2 promóter (ProSUC2) a szállítószövetekben történő fehérjetermeltetésre alkalmas (Mitra és mtsai., 1989; Sessions és mtsai., 1999; Srivastava és mtsai., 2008 Hategan és mtsai., 2014; Kirchenbauer és mtsai., 2016). A promóterek müködését a transzgenikus csíranövényeinken vizsgálva ellenőriztük, hogy a ProML1 az YFP-UVR8 fehérjét valóban a csíranövények epidermiszében termelte (a sziklevélben és hipokotilban egyaránt) (7. ábra G-I, 8. ábra D), felnőtt növények szárában szintén az epidermiszben tudtunk YFP-UVR8-at detektálni (9. ábra). A ProCAB3 a csíranövények sziklevelében a mezofillben (7. ábra $\mathbf{D}, \mathbf{8}$. ábra $\mathbf{H}$ ), valamint a hipokotiljuk szubepidermális sejtjeiben (7. ábra E, F) találtunk YFP-UVR8-at, felnőtt növényekben pedig a szár kortexében tudtunk YFP-UVR8-at nagy mennyiségben detektálni (9. ábra). A várakozásoknak megfelelően nem észleltük ezeknek a promótereknek az aktivitását a szállítószövetekben (7. ábra D-I, 8. ábra D-I, 9. ábra). A várakozással ellentétben a ProSUC2 nem csak a hipokotil és a sziklevelek szállítószöveteiben, hanem szubepidermális sejtjeiben is mutatott aktivitást csíranövényekben (7. ábra J-L, 8. ábra J-L), felnőtt növények szárában pedig a kortexben és a szállítószövetekben figyeltünk meg számottevő YFP-UVR8 jelet (9. ábra). 


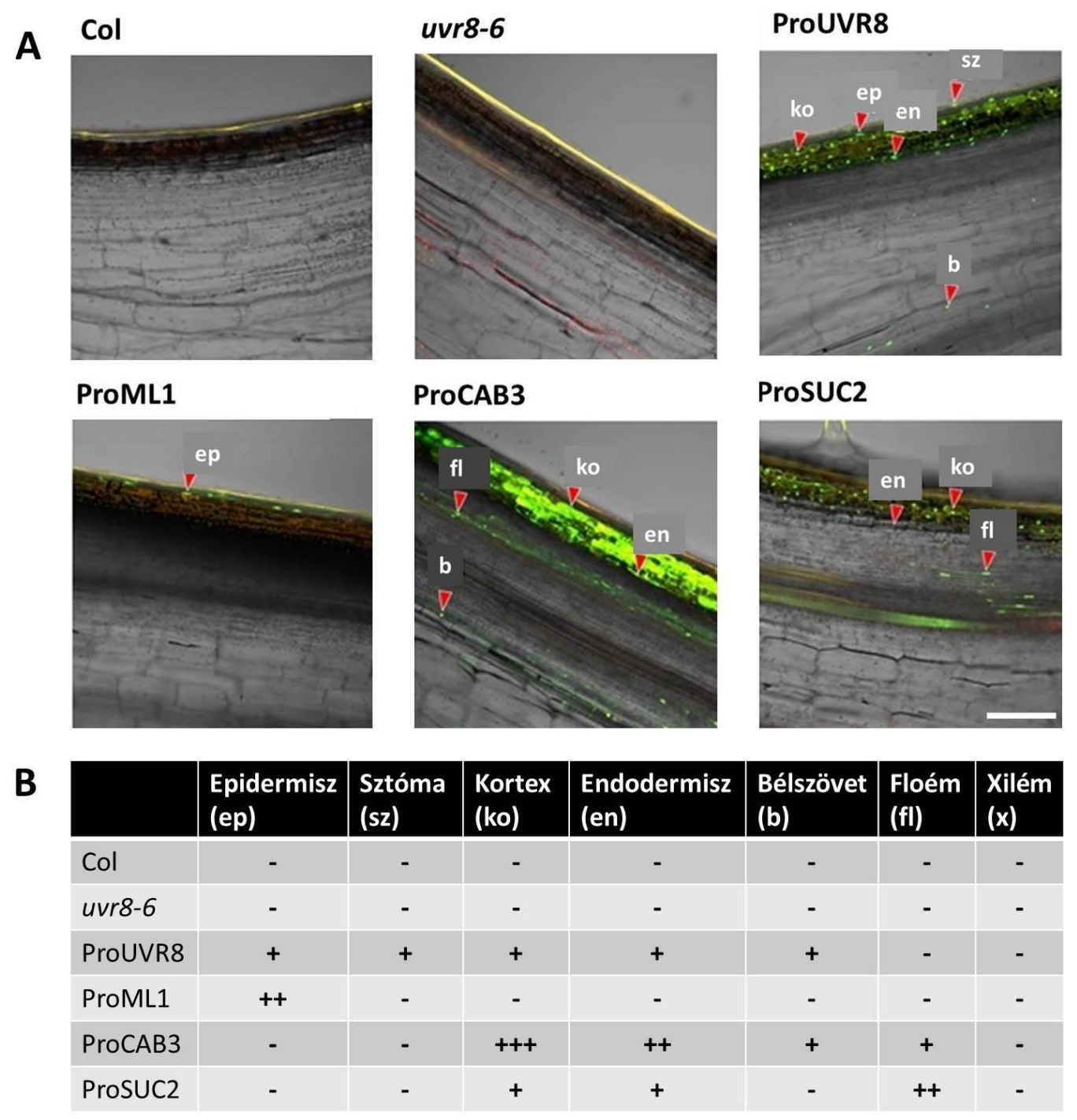

9. ábra: Az YFP-UVR8 fúziós fehérje kimutatása transzgenikus felnőtt növények szárában, különböző szövetekben

A) Felnőtt növények szárából készült hosszmetszeteken vizsgáltuk CLSM-mel az YFP-UVR8 termelödésének helyeit. Az YFP jeleket bemutató képeket és a fehér fénnyel átvilágított metszeti képeket egymásra illesztve ábrázoltuk. A piros nyilak az YFP-UVR8-ból származó YFP jeleket mutaták. A rövidítések: $\mathrm{sz}=$ sztóma, $\mathrm{ep}=$ epidermisz, $\mathrm{ko}=$ kortex, en $=$ endodermisz, $\mathrm{fl}=$ floém, $\mathrm{b}=$ bélszövet. A méret vonal $100 \mu \mathrm{m}-\mathrm{t}$ mutat.

B) Afelnött növény részletesen vizsgálható szöveteiben elöforduló fluoreszcens jelek összesítő táblázata. Jelölések: (-): nincs YFP-UVR8, (+): kevés YFP-UVR8, (++): közepes mennyiségü YFP-UVR8, (+++): nagyon sok YFP-UVR8 az adott szövetben.

Western blot analízis segítségével megállapítottuk, hogy a vad típusú csíranövényben mérhető endogén UVR8 szinthez képest az általunk használt ProML1 vonalban az összes YFP-UVR8 fehérje szintje hozzávetőlegesen 5\%, a ProSUC2-ben 25\%, míg a ProCAB3 vonalban 75\% (10. ábra A). Ezzel a módszerrel azonban csak a csíranövényekben előforduló összes YFP-UVR8 mennyisége határozható meg, külön-külön az egyes szövetekben termelődött mennyiségek nem. A növényekben található össz-UVR8 mennyiség mellett azt is fontos volt tudnunk, hogy az egyes vonalak szövetei mennyi YFP-UVR8-at tartalmaznak, ezért a 
fehérjeszinteket CLSM-mel is megmértük. Ezzel a megközelítéssel vizsgálva a különböző szövetekben található YFP-UVR8 mennyiségek egymással összehasonlíthatóak a mikroszkópos képeken látható YFP jelek lemérése alapján (10. ábra B, C). Az YFP-UVR8 fehérje mennyisége az epidermiszben hasonlónak mutatkozott a ProUVR8 és a ProML1 vonalakban (10. ábra B), a ProUVR8 mezofilljéhez képest pedig 4-5-ször több fehérje van a ProCAB3 vonal mezofill sejtjeiben (10. ábra C), míg ugyanott a ProSUC2 vonal a ProUVR8-ban mérthez hasonló szintet mutat (10. ábra C). Ezzel a módszerrel csak a felszínhez közelebbi szövetekben termelt YFP-UVR8 fehérje szint állapítható meg precízen, a mélyebben elhelyezkedő szállítószövetekben a jelek erősségét így nem tudtuk vizsgálni.

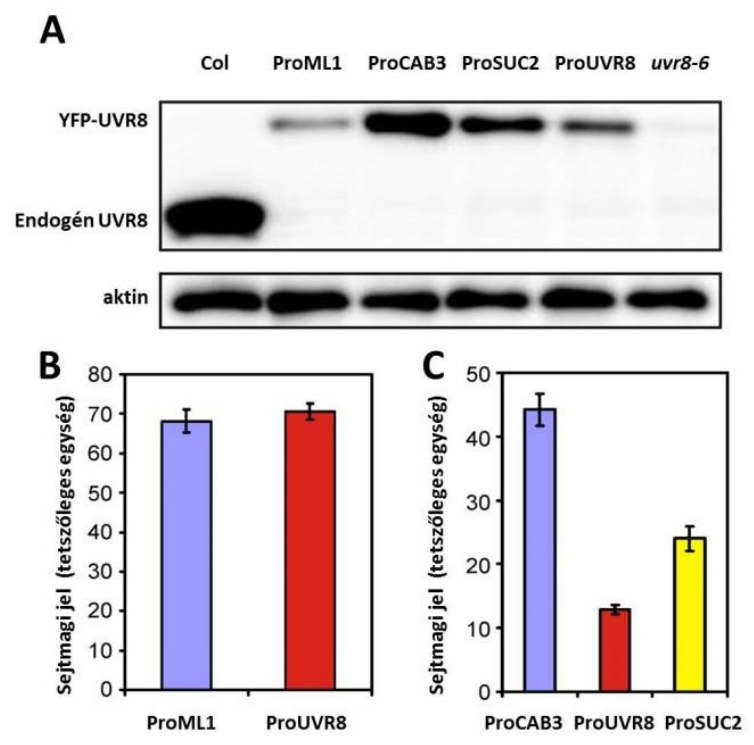

\section{0. ábra: Az YFP-UVR8 fehérje szintje a transzgenikus csíranövények különböző szövettípusaiban}

A) Endogén UVR8 és YFP-UVR8 fehérjeszintek meghatározása Western blot módszerrel. $\mathrm{Az}$ összfehérje kivonatokat folyamatos, UV-B sugárzással kiegészített fehér fényben nevelt négynapos csíranövényekből nyertük. A fehérjéket UVR8 specifikus ellenanyaggal (anti-UVR8) mutattuk ki. A minták felvitelének pontosságát anti-aktin ellenanyaggal ellenőriztük. B-C) Az YFP-UVR8 felhalmozódás vizsgálata CLSM-mel: az uvr8-6 háttérben kifejeztetett YFP-UVR8 fehérjékből származó fluoreszcens jeleket vizsgáltuk a ProUVR8, és a ProML1 vonalak sziklevelének epidermiszében (B), valamint a ProCAB3 és ProSUC2 vonalak epidermisz alatti sejtrétegében (mezofill) (C). A hibasávok az átlagok standard hibáját mutatják $(n>60)$.

\subsection{A különböző szövetekben termelt YFP-UVR8 hatásai}

\subsubsection{Csíranövények kis intenzitású UV-B sugárzás hatására bekövetkező fotomorfogenikus válaszai}

Munkánk során célunk volt felderíteni, milyen funkciókat lát el az UVR8 fehérje a különböző szövetekben: vannak-e specifikus, szövettípusokra jellemző válaszok, folyamatok, esetleg találunk-e kapcsolatot a különböző szövetekből elinduló, UVR8 által kiváltott jelátviteli folyamatok müködése között. A fölmerült kérdések megválaszolása érdekében transzgenikus csíranövényeinkben megvizsgáltuk az UV-B hatására adott legfontosabb fotomorfogenikus válaszokat: a hipokotil nyúlás gátlását, valamint a sziklevelek növekedését. Az általunk használt gyenge UV-B-kezelés alkalmas arra, hogy a fotomorfogenikus hatásokat vizsgáljuk, ugyanis a 
kezelés hatására a hipokotil megnyúlás gátlása erösödött a vad típusú csíranövények esetében, míg az uvr8 mutánsok sokkal kisebb, elhanyagolható mértékủ választ adtak (11. ábra A). Ezek a megfigyeléseink megerősítik a korábban közölt kísérletek eredményeit (Favory és mtsai., 2009) és igazolják, hogy az alkalmazott sugárzás nem (csak) általános, hanem UVR8-specifikus választ vált ki. Mindegyik transzgenikus vonalunk jól mérhető hipokotil megnyúlás gátlás választ mutatott, de egyik sem volt képes teljes mértékben helyreállítani az $u v r 8$ mutáns fenotípust. A ProUVR8 (YFP-UVR8 termeltetés endogén promóterrel) és a ProML1 (YFP-UVR8 az epidermiszben) vonalak hasonló intenzitású választ mutattak, a ProCAB3 (YFP-UVR8-at a mezofillben termelő) vonal esetében figyelhettük meg a leghangsúlyosabb, a ProSUC2 (YFP-UVR8 a szállítószövetben és a mezofillben) vonalnál pedig a leggyengébb válaszreakciót (11. ábra $\mathbf{A}$ ).

Megvizsgáltuk azt is, hogyan változik a sziklevelek felületének mérete UV-B besugárzás hatására: az uvr8 mutáns, a ProCAB3 és a ProSUC2 csíranövények szikleveleinek csökkent a felülete, ezzel szemben a ProUVR8, ProML1 esetében a vad típusú növényekhez hasonló, kismértékü sziklevél felületnövekedést tapasztaltunk (11. ábra B).
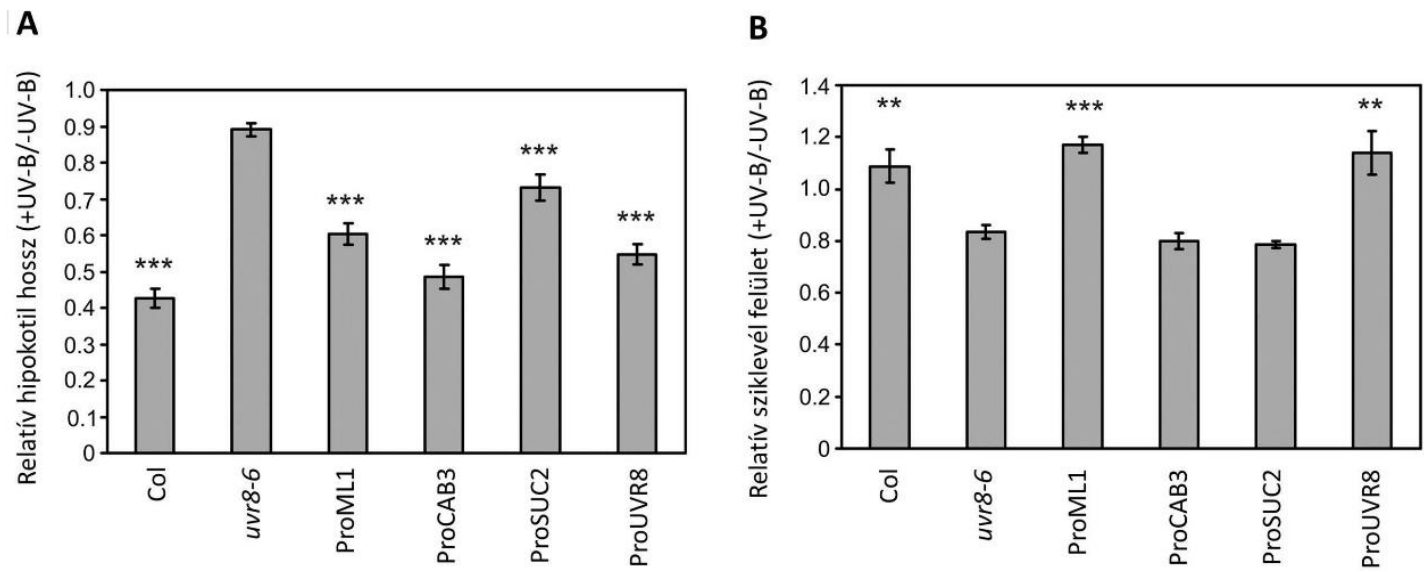

11. ábra: uvr8 mutáns fenotípus komplementálása különböző szövetekben kifejeztetett YFP-UVR8 fotoreceptorral

A) Az UV-B sugárzás hatása a hipokotilhosszra. Az UV-B-vel kiegészített (+UV-B) és UV-B nélküli (-UV-B) folyamatos fehér fényben 4 napig nevelt csíranövények hipokotiljának hosszát mértük le és a relatív hosszt ábrázoltuk (+UV-B/-UV-B).

B) UV-B sugárzás hatása a sziklevél-felületre. Az UV-B-vel kiegészített (+UV-B) és UV-B nélküli (-UV-B) folyamatos fehér fényben 4 napig nevelt csíranövények szikleveleinek felületét mértük le, a relatív felületet ábrázoltuk (+UV-B/-UV-B).

A-B) Minden mérést háromszor ismételtünk, az átlagokat ábrázoltuk. A hibasávok a standard hibát mutatják (A: $\mathrm{n}>30, \mathrm{~B}: \mathrm{n}>100$ ). Csillagokkal jelöltük azokat a vonalakat, amelyek számottevő eltérést mutatnak az uvr8 mutánshoz képest a Student-féle $t$-próba alapján (szignifikancia: ${ }^{*} \mathrm{P}<0.05,{ }^{* *} \mathrm{P}<0.01,{ }^{* * *} \mathrm{P}<0.005$ ).

$\mathrm{Az}$ eredményeket összesítve kijelenthetjük, hogy az YFP-UVR8 fúziós fehérje funkcióképes UV-B fotoreceptorként müködik a transzgenikus vonalainkban, ami összhangban áll a korábban leírt eredményekkel (Brown és mtsai., 2005; Kaiserli és Jenkins, 2007; Huang és mtsai., 2014; Binkert és mtsai., 2016). Ezen kívül megállapíthatjuk, hogy az epidermiszben és 
a mezofill/szubepidermális sejtekben található UVR8 fotoreceptor egyaránt hozzájárul az UV-B indukált hipokotil megnyúlás gátlásához, együttes hatásuk szükséges a teljes értékü válaszhoz. $\mathrm{Az}$ eredmények arra is rávilágítanak, hogy UV-B fényben a megfelelö sziklevél felületnövekedéshez nélkülözhetetlen az epidermiszben kifejezett UVR8, mivel ezt a funkciót a mezofill/szubepidermális sejtekben található UVR8 nem képes megfelelően ellátni, így ez a szabályozási mód szöveti autonómiát mutat (csíranövény növekedési fázisban). Kiderült továbbá, hogy a szállítószövetekben található UVR8-nak valószínűleg nincs számottevő szerepe a vizsgált fotomorfogenikus válaszok szabályozásában.

\subsubsection{Az UV-B sugárzás hatásai a felnőtt növények növekedésére}

Vizsgálatainkat héthetes növényeken végeztük. Elöször azt bizonyítottuk, hogy mind az uvr8 mutáns, mind pedig az uvr8 háttérben YFP-UVR8 fehérjét különböző szövetekben kifejező vonalak fehér fényben ugyanúgy fejlődtek, mint a vad típusú Arabidopsis (12. ábra A, B). A kísérletben használt növények egy részét a fehér fény mellett kiegészítő UV-B-vel is besugároztuk. A használt alacsony intenzitású kiegészítő UV-B sugárzás a vad típusú növények tőlevélrózsáinak növekedését és a levélnyél megnyúlását gátolta. Ezzel ellentétben az uvr8 mutáns növények tőlevélrózsáinak növekedését alig befolyásolta, ezen kívül a mutánsok levelei világoszöldek voltak, tehát ezekben a növényekben az UV-B érzékelés valóban sérült (12. ábra A, B). Ez a megfigyelésünk összhangban áll a korábban leírtakkal (Favory és mtsai., 2009). A kiváltott válaszok alapján arra lehet következtetni, hogy az általunk használt gyenge kiegészítő UV-B sugárzás föleg az UVR8 által kiváltott fotomorfogenikus és akklimációs válaszokat indította el. Az YFP-UVR8-at különböző szövetekben expresszáló transzgenikus vonalaink hasonlóan válaszoltak az UV-B sugárzásra, mint a vad típusú növények. Tőlevélrózsáik mérete és struktúrája a vad típuséhoz hasonló volt, kivéve a kisebb méretű tőlevélrózsával rendelkező ProCAB3 növényeket (12. ábra A, B).

Az UVR8 szükséges a fotoszintézis hatékonyságának fenntartásához UV-B sugárzásban (Davey és mtsai., 2012), ezért megmértük a növények klorofilltartalmát is, ami alapján erről a szabályozási útvonalról kaphatunk képet. Minden növényben hasonló klorofill-mennyiséget mértünk UV-B kezelés nélkül, UV-B hatására azonban az uvr8 mutáns kivételével minden vizsgált növényben (legnagyobb mértékben a ProCAB3 növényekben) nőtt a klorofill mennyisége (12. ábra C).

Az előzőekben leírt vizsgálatokban gyenge kiegészítő UV-B sugárzást alkalmaztunk, azonban ha nagyobb dózisban adunk kiegészítő UV-B sugárzást a fehér fényhez, vizsgálhatjuk a növények UV-B toleranciájának kialakulását is. Ezekhez a vizsgálatokhoz úgy választottuk meg a kiegészítő UV-B sugárzás dózisát, hogy ahhoz a vad típusú növények még képesek legyenek alkalmazkodni, míg az uvr8 mutáns növényekre nézve már letális legyen (12. ábra A). 
Ilyen körülmények között a vad típusú növények mellett képesek voltak túlélni a ProUVR8 és a ProML1 növények is, bár tőlevélrózsájuk kisebb volt, mint a vad típusé. A ProCAB3 és a ProSUC2 növények viszont erôs UVR8 túltermelő fenotípust mutattak (12. ábra A, B), hasonlóképp azokhoz a növényekhez, amikben az UVR8 termelését folyamatosan magas szintű expressziót biztosító promóter (például Pro35S) szabályozza (Favory és mtsai., 2009; Heijde és mtsai., 2013; Fasano és mtsai., 2014). Ez összefügg azzal, hogy ezek a növények, a csíranövényekhez hasonlóan, felnőtt korukban is magas szinten termelték az YFP-UVR8 fehérjét (13. ábra). A kapott eredmények alapján kijelenthetjük, hogy hasonló körülmények között az epidermális és mezofillben/kortexben található UVR8 fotoreceptor egyaránt hatékonyan képes elősegíteni az UV-B tolerancia kialakulását, következésképpen a felnőtt növények túlélését. 
A

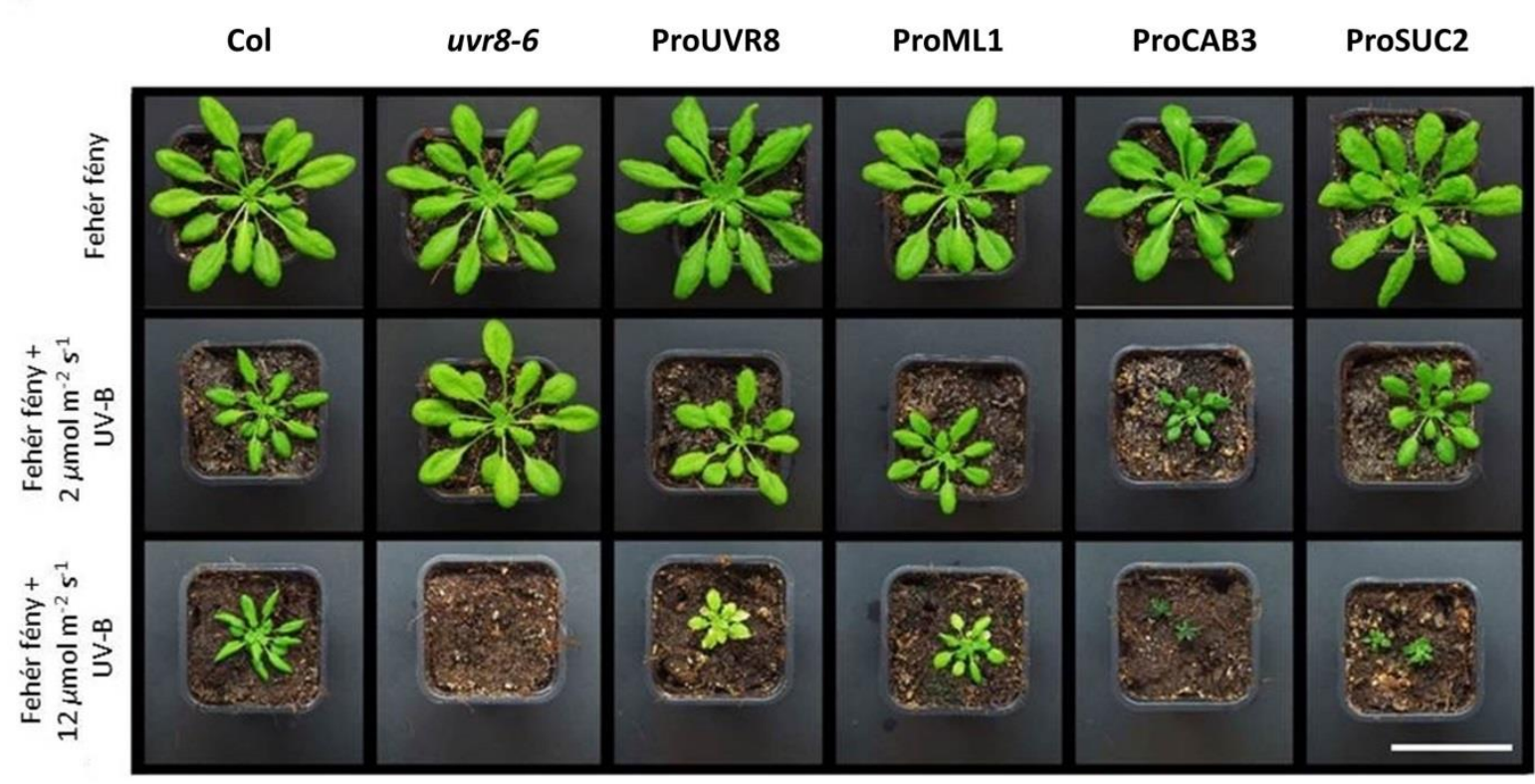

B

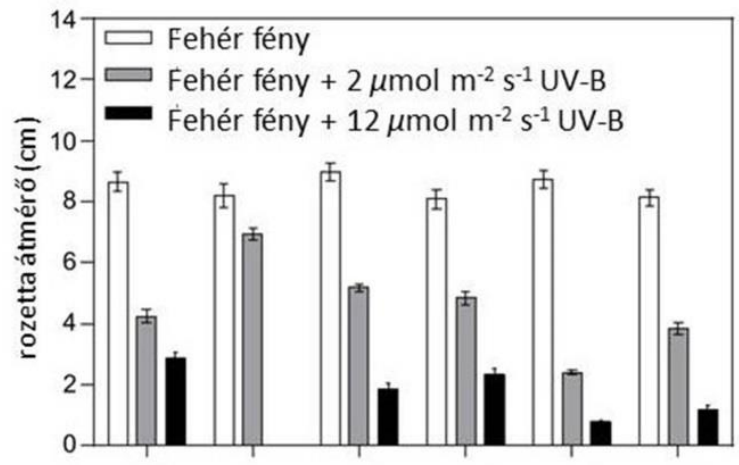

Col uvr8-6 ProUvR8 ProML1 ProCAB3 ProSUC2
C

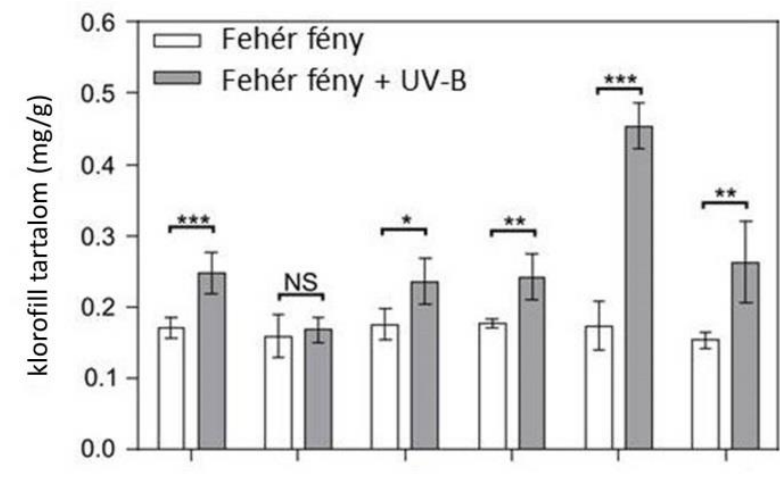

Col uvr8-6 ProUvR8 ProML1 ProCAB3 ProSUC2

\section{2. ábra: Különböző szövetekben előforduló YFP-UVR8 hatásai felnőtt Arabidopsis növényben}

A) Héthetes Arabidopsis növények fehér fényben, valamint gyenge $\left(2 \mu \mathrm{mol} \mathrm{\textrm {m } ^ { - 2 }} \mathrm{s}^{-1}\right)$, illetve erős

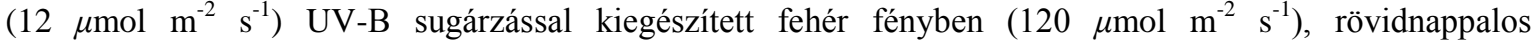
körülmények között nevelve. A méret vonal $5 \mathrm{~cm}$-t mutat.

B) A fentebb leírt körülmények között nevelt növények tőlevélrózsáinak átmérője. A hibasávok az átlag értékek standard hibáját mutatják $(\mathrm{n}>10)$.

C) Héthetes, fehér fényen, illetve UV-B-vel $\left(1,5 \mu \mathrm{mol} \mathrm{m}^{-2} \mathrm{~s}^{-1}\right)$ kiegészített fehér fényen nevelt növények klorofilltartalma (mg klorofill/g friss tömeg). Minden növényi vonalból öt-öt növényt használtunk biológiai ismétlésként, minden fénykezelésnél. A hibasávok az átlag értékek standard hibáját mutatják $(\mathrm{n}=5)$. Csillaggal jelöltük azokat az UV-B kezelt növényekböl származó értékeket, amelyek ugyanabban a genotípusban jelentősen eltérnek a fehér fényben nevelt növények értékeitöl. (Student-féle $t$-próba alapján, ${ }^{*} \mathrm{P}<0.05,{ }^{*} \mathrm{P}<0.01,{ }^{* * *} \mathrm{P}<0.005$, NS: nem szignifikáns.) 


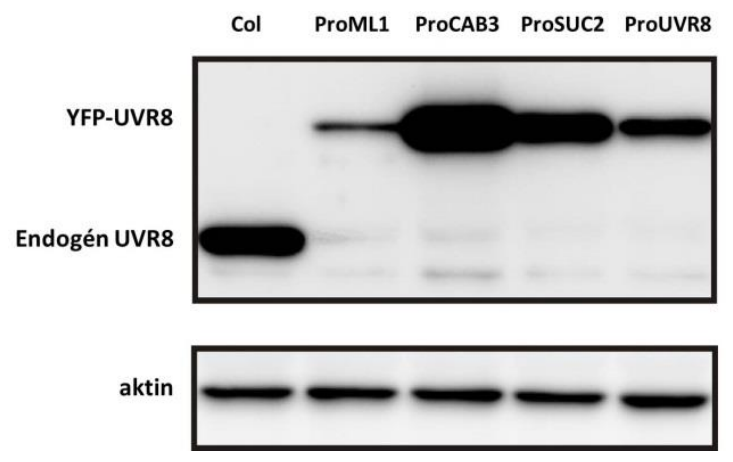

\section{3. ábra: Endogén UVR8 és YFP-UVR8 \\ fehérjeszint meghatározása felnőtt növényekben}

Rövidnappalos körülmények között nevelt héthetes növényekből készítettünk összfehérje kivonatot, melyböl Western blot módszerrel antiUVR8 ellenanyag segítségével mutattuk ki az endogén UVR8, illetve az YFP-UVR8 fehérjét. $\mathrm{Az}$ egyenletes mintafelvitelt anti-aktin ellenanyaggal ellenőriztük.

\subsubsection{Fototropizmus}

A csíranövények UV-B sugárzás irányába történő hipokotil elhajlását már körülbelül 30 éve megfigyelték (Baskin és Iino, 1987), de annak kiderítésére, hogy ez a válaszreakció a fototropinok és az UVR8 müködése révén valósul meg, a közelmúltig várni kellett (Vandenbussche és mtsai., 2014). Ezzel ellentétben eddig nem állt rendelkezésre adat arra vonatkozóan, hogy vajon a felnőtt növények virágzati tengelye (szára) is elhajlik-e a csíranövények hipokotiljához hasonlóan az egy irányból érkező UV-B sugárzás felé, és ha igen, ennek molekuláris szabályozása eltér-e a csíranövények hasonló reakciójától. Ennek vizsgálatára olyan növényeket világítottunk meg egyik oldalról UV-B-vel, melyek virágzati tengelye legalább $5 \mathrm{~cm}$ magas volt $(5-10 \mathrm{~cm})$ és megmértük a bekövetkező elhajlást. Kísérleteink azt mutatják, hogy a felnőtt vad típusú növények szára elhajlik az UV-B sugárzás irányába (14. ábra). Míg ez az elhajlás már 4 óra UV-B kezelést követően teljesen kialakul, addig az uvr8 mutáns növények alig reagálnak az egyoldali UV-B kezelésre, tehát az UVR8 biztosan szükséges a válasz kiváltásához. Ezek az eredmények a fototropinokra nézve is új információval szolgálnak, hiszen kiderült, hogy a csíranövény fázissal ellentétben a fototropinok nem játszanak fontos szerepet felnőtt növényekben a fototropikus elhajlás szabályozásában. Kísérleti eredményeink ezt megerősítik, hiszen a fototropinokat nem tartalmazó photlphot 2 mutáns növények a vad típusúakhoz hasonlóan hajlanak az UV-B forrás irányába (14. ábra). A fototropinok felnőtt korban betöltött szerepét a szárelhajlásban hármas mutáns (phot1phot2amiUVR8) növények segítségével vizsgáltuk, amiben a phot1phot2 háttérben az UVR8 gén funkcióját egy, a gént célzó mesterséges mikroRNS kifejeztetése gátolja (Vandenbussche és mtsai., 2014). Ezek a növények egyáltalán nem reagálnak az egyoldali UV-B kezelésre, tehát csak az uvr8 mutánsoknál megfigyelhető minimális elhajlásért felelősek a fototropinok felnőtt korban

\section{(14. ábra).}


A

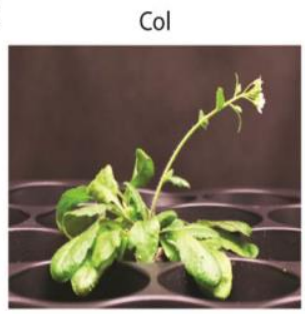

phot1-5phot2-1

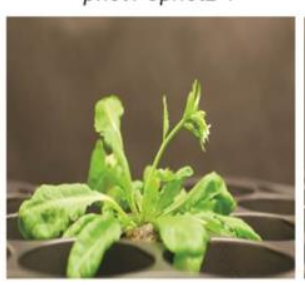

uvr8-6

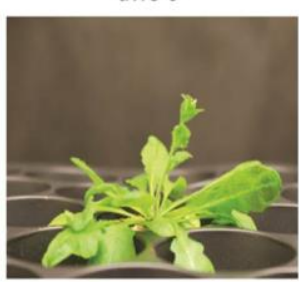

phot1-5phot2-1amiUVR8

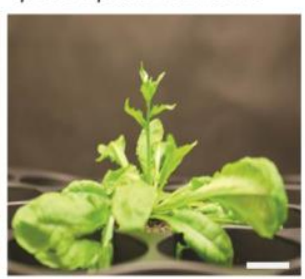

B

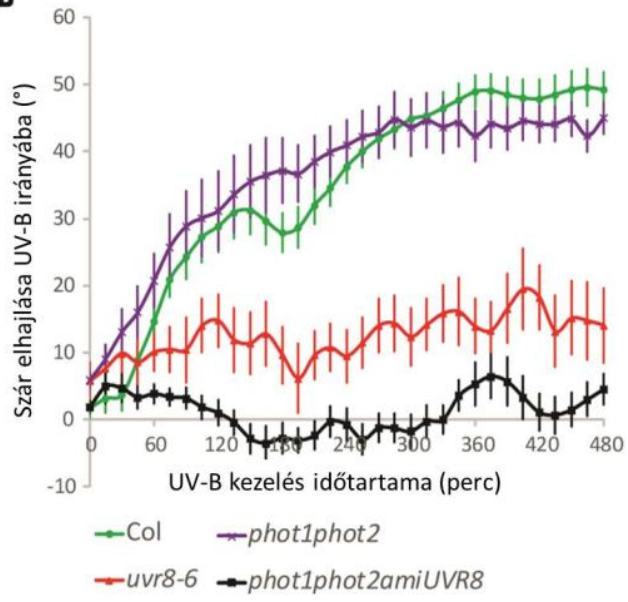

14. ábra: A fototropinok és az UVR8 szerepe felnőtt növények szárának UV-B irányú elhajlásában

Minimum $5 \mathrm{~cm}$-es (körülbelül 5-10 cm-es) virágzati szárral rendelkezö, hosszúnappalos körülmények között nevelt, felnött növények oldalirányú UV-B sugárzás $\left(1,5 \mu \mathrm{mol} \mathrm{m}^{-2} \mathrm{~s}^{-1}\right.$ UV-B $+2,5 \mu \mathrm{mol} \mathrm{m}^{-2} \mathrm{~s}^{-1}$ fehér fény) felé történő szárelhajlását mértük meg.

A) Az UV-B besugárzás jobb oldalról történt. A méret vonal $1 \mathrm{~cm}-\mathrm{t}$ mutat.

B) A növények szárelhajlása folyamatos egyirányú UV-B sugárzásban. A hibasávok az átlagok standard hibáját mutatják $(n>10)$.

A következő kísérletben megvizsgáltuk a különböző szövetekben található UVR8 szerepét a virágzati tengely elhajlásának szabályozásában. A vad típuséhoz hasonló elhajlást mutatott az YFP-UVR8-at endogén UVR8 promóterrel kifejező ProUVR8, valamint az YFP-UVR8-at a kortexben termelö ProCAB3 vonal is. Az YFP-UVR8 fehérjét a szállítószövetben és kis mennyiségben a kortexben is termelő ProSUC2 és az epidermiszben alacsony szinten termelő ProML1 vonal csak részlegesen reagált az UV-B kezelésre, míg az uvr8 mutáns az előző méréshez hasonlóan csak nagyon kismértékü elhajlásra volt képes (15. ábra). Az eredmények alapján arra következtetünk, hogy felnőtt növényben az egyoldali UV-B sugárzás irányába megfigyelhető elhajlást leginkább a mezofillben/kortexben található UVR8 szabályozza, de az epidermális UVR8-nak is van ebben szerepe, míg a szállítószövetekben lévő UVR8 fotoreceptor nem járul hozzá jelentősen a szárelhajlás kialakulásához. Az eredmények továbbá arra utalnak, hogy bizonyos mértékig az UVR8 mennyisége is befolyásolja a szár elhajlását. 


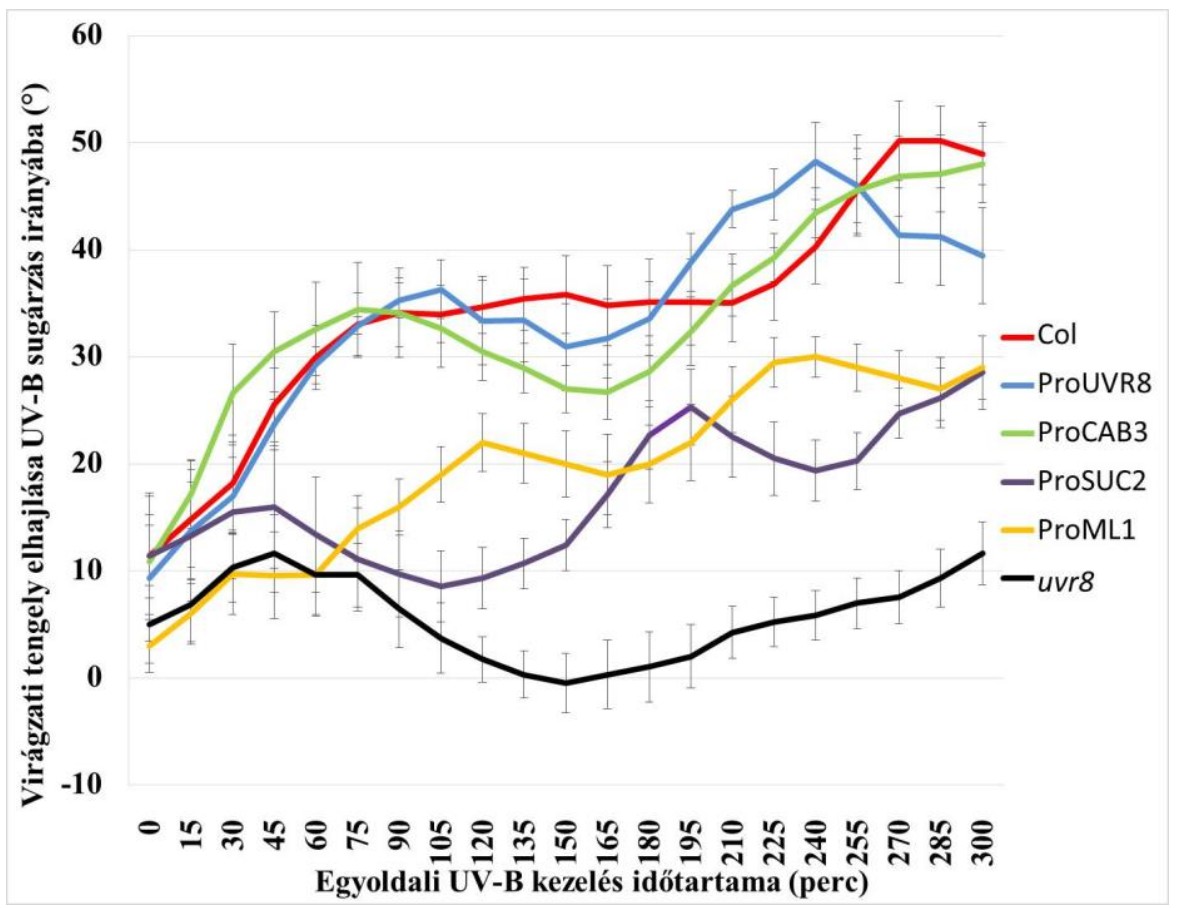

15. ábra: Az oldalirányú UV-B sugárzásban tapasztalható szárelhajlás különböző transzgenikus vonalakban

Minimum $5 \mathrm{~cm}$-es (körülbelül 5-10 cm-es) virágzati szárral rendelkezö, hosszúnappalos körülmények között nevelt, felnőtt növényeket oldalról, egy irányból UV-B sugárzással $\left(1,5 \mu \mathrm{mol} \mathrm{m}^{-2} \mathrm{~s}^{-1} \mathrm{UV}-\mathrm{B}+2,5 \mu \mathrm{mol} \mathrm{m} \mathrm{m}^{-2} \mathrm{~s}^{-1}\right.$ fehér fény) kezeltünk, majd a száruk elhajlását megmértük. A hibasávok az átlagok standard hibáját mutatják $(n>10)$.

\subsubsection{Flavonoid felhalmozódás}

A növények UV-B sugárzás hatására aktiválódó védekező reakciói közé tartozik az UV-B szürő flavonoidok felhalmozódása. A DPBA nevü vegyület fluoreszkáló komplexet képez a flavonoid molekulákkal, amit CLSM segítségével több különböző növényi rendszerben vizsgáltak korábban (Schnitzler és mtsai., 1996; Hutzler és mtsai., 1998; Peer és mtsai., 2001). Csíranövényeken végzett kísérleteink során olyan mértékű UV-B sugárzással kiegészített megvilágítást alkalmaztunk, ami az uvr8 mutánsokban nem, a vad típusú csíranövényekben viszont kimutatható mértékü flavonoid felhalmozódást váltott ki (16. ábra). A legerősebb flavonoidspecifikus jelet az adaxiális epidermisz és mezofill szövetréteg határán észleltük, a korábbi megfigyelésekhez hasonlóan (Hutzler és mtsai., 1998; Agati és mtsai., 2011). Az UV-B hatására a vad típusú és az YFP-UVR8-at termelő transzgenikus növényi vonalaink esetében is kimutatható volt a flavonoidok UVR8-függő felhalmozódása, bár a transzgenikus vonalainkban ennek mértéke alacsonyabb volt a vad típusban tapasztalthoz képest (16. ábra). Mindez arra utal, hogy mindegyik vizsgált szövetben előforduló YFP-UVR8 hozzájárul a flavonoidok akkumulációjához, a teljesértékü válaszhoz szükséges a különböző szövetekben lejátszódó folyamatok együttes hatása. 

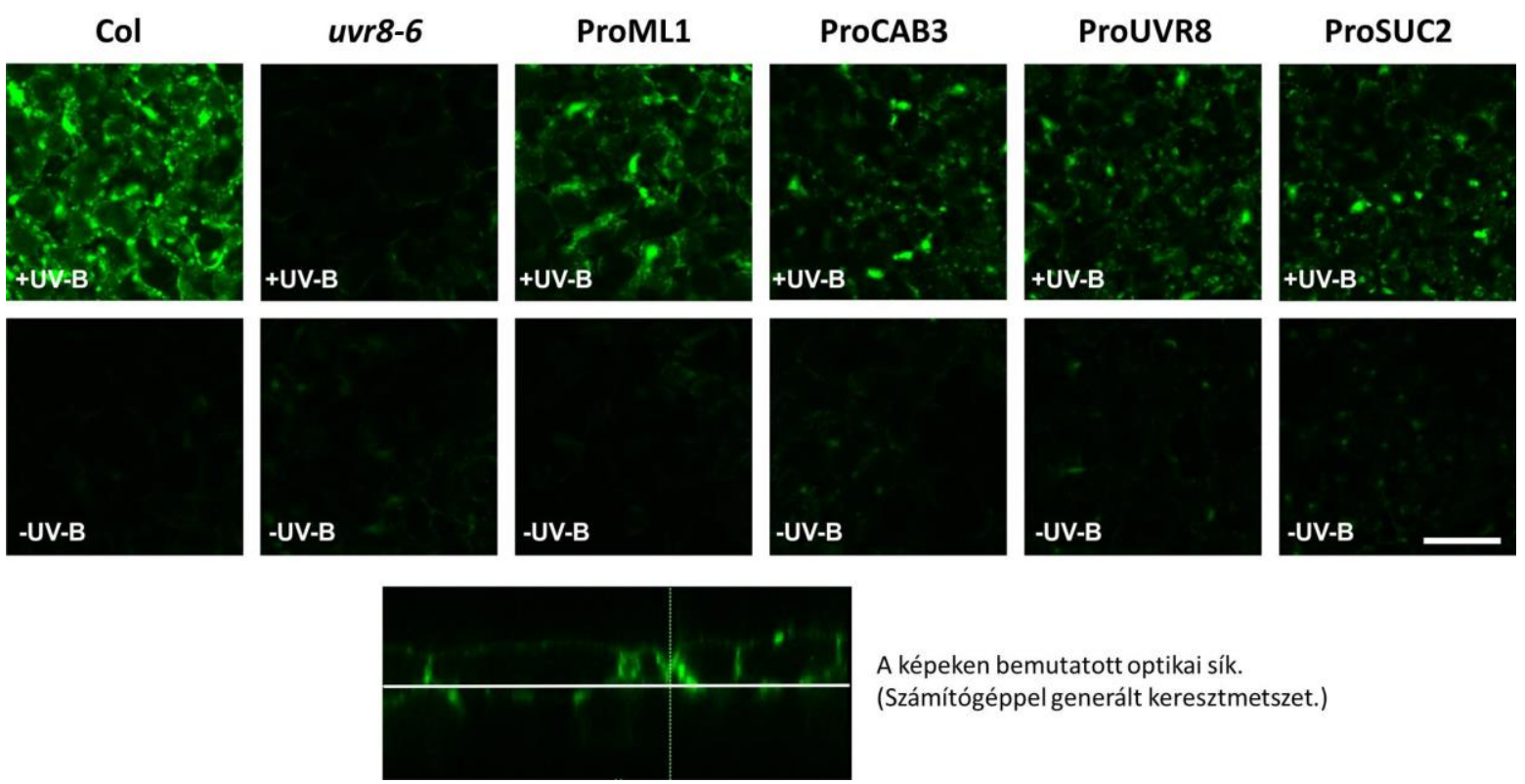

A képeken bemutatott optikai sík. (Számítógéppel generált keresztmetszet.)

16. ábra: UV-B által kiváltott flavonoid felhalmozódás transzgenikus csíranövények epidermiszében

Gyenge $\left(2 \mu \mathrm{mol} \mathrm{m} \mathrm{m}^{-2} \mathrm{~s}^{-1}\right)$ UV-B sugárzással kiegészített fehér fényben $\left(120 \mu \mathrm{mol} \mathrm{m} \mathrm{m}^{-2} \mathrm{~s}^{-1}\right)$ nőtt háromnapos csíranövényeket további négy napig neveltünk WG305 (+UV-B) filterrel, vagy WG385 (-UV-B) filterrel letakarva. DPBA kezelést követően CLSM segítségével vizsgáltuk a DPBA-flavonoid komplexek előfordulását. Az összes kép ugyanazzal a beállítással készült. A fókuszfelületet az adaxiális epidermisz alsó felére állítottuk be, ahol a legerősebb jeleket észleltük (alsó panel). A méret vonal $50 \mu \mathrm{m}$-t mutat.

Az UVR8 nem csak a csíranövényekben, hanem a felnőtt növényben is szerepet játszik az UV-B sugárzás káros hatásainak mérséklésében, többek között a flavonoidok felhalmozódásában is (Peer és mtsai., 2001; Favory és mtsai., 2009). Az 5-10 cm-es szárral rendelkező felnőtt növényeket egy oldalról UV-B-vel $\left(1,5 \mu \mathrm{mol} \mathrm{m}^{-2} \mathrm{~s}^{-1}\right)$ világítottuk meg, majd alkoholos fixálást követően DPBA festéssel tettük láthatóvá a szárban felhalmozódott flavonoidokat. Vibratóm készülékkel metszeteket készítettünk, amiket azután CLSM-mel vizsgáltunk. Azt találtuk, hogy a vad típusú növények szárában leginkább az epidermiszben és a kortexben halmozódtak fel flavonoidok, de az endodermiszben és a bélszövetben is sikerült jelet detektálnunk, míg az uvr8 mutáns növények nem termeltek flavonoidokat kimutatható mennyiségben (17. ábra). Az általunk megfigyelt flavonoid-felhalmozódás tehát UVR8-függő. Az YFP-UVR8-at a kortexében nagy mennyiségben termelő ProCAB3 növények metszeteiben bármelyik szövetet vizsgáljuk (epidermisz, kortex, endodermisz, bélszövet), mindegyikben több flavonoidot látunk, mint akármelyik másik vizsgált vonalunk esetében. Erre magyarázat lehet, hogy a ProCAB3 a legerősebb YFP-UVR8 túltermelő vonalunk (13. ábra, 17. ábra). A ProML1, ProUVR8 vonalak a vad típusú növényekhez hasonló mennyiségben halmozták fel a flavonoidokat az epidermiszben, míg a ProSUC2 vonal epidermiszében csak kis mennyiségü flavonoidot tudtunk kimutatni. 
A ProML1 és az uvr8 mutáns növényeken kívül mindegyik vonalban találtunk flavonoidokat a bélszövetben és az endodermiszben is (17. ábra).

Érdekes jelenség, hogy az epidermiszben YFP-UVR8-at nem termelő transzgenikus vonalak (ProCAB3, ProSUC2) epidermiszében is sikerült flavonoidokat detektálni, amit vagy az UVR8 által elindított jelek terjedése, vagy a flavonoidok transzportja okozhat és az epidermisz UV-B elleni védekezésben betöltött kiemelt szerepére utal. Az YFP-UVR8-at epidermiszben termelő ProML1 vonal szárában viszont csak az epidermiszben találtunk nagy mennyiségü flavonoidot, ami alapján az UVR8 jel és/vagy a flavonoid transzport csak a kortexből az epidermisz felé irányul, visszafelé nem (17. ábra). Ez szintén az epidermisz kiemelt szerepét támasztja alá.

A vad típusban és az összes transzgenikus vonalunkban jól látható különbség alakult ki a megvilágított oldal és az árnyékos oldal flavonoid felhalmozódása között: minden esetben a megvilágított oldalon halmozódott fel több flavonoid (17. ábra). Ez arra utal, hogy legalábbis ebben a folyamatban az UVR8 ott fejti ki hatását, ahol az UV-B sugárzás miatt aktív állapotba kerül, vagyis az UVR8 jel nem terjed el a növény árnyékos részei felé. 


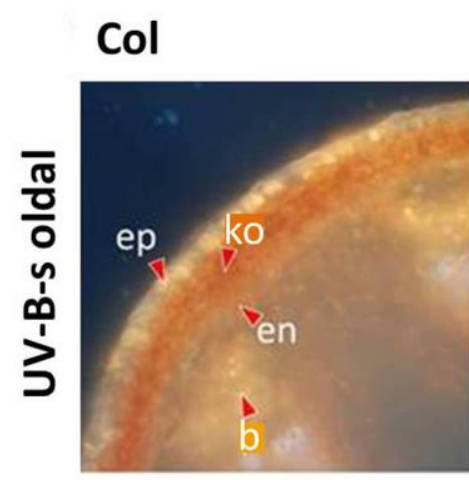

\section{uvr8-6}
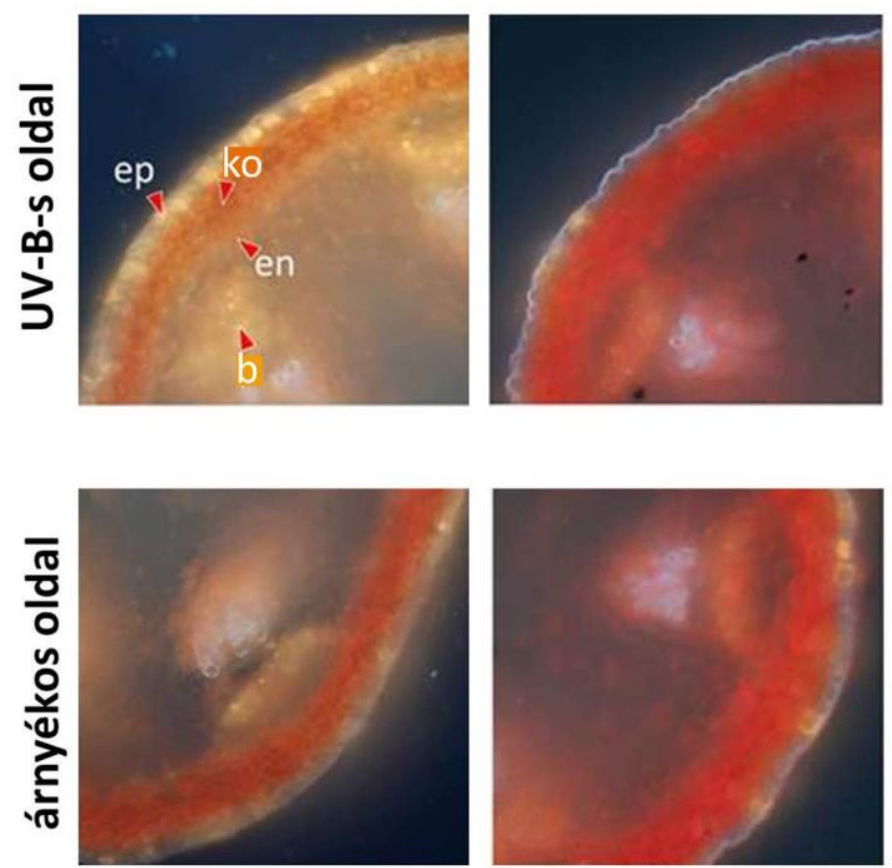

ProML1
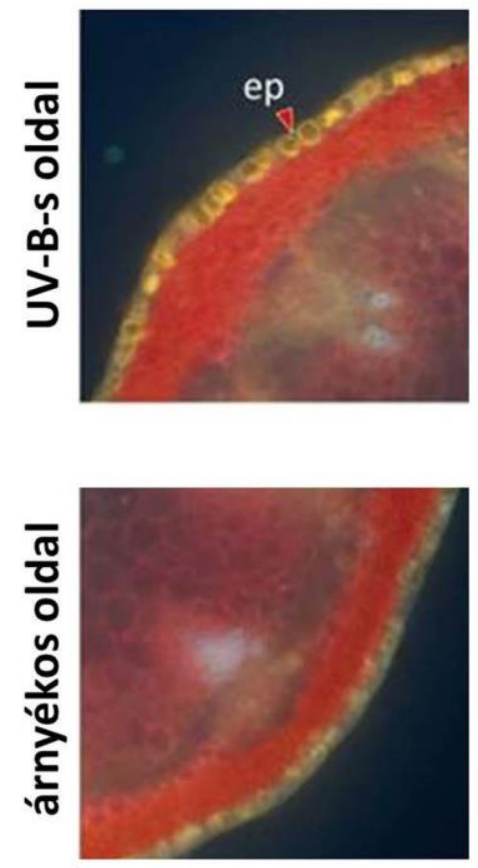

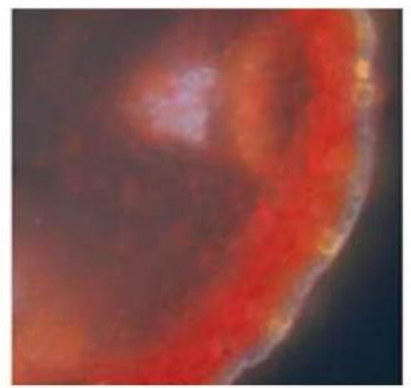

\section{ProCAB3}
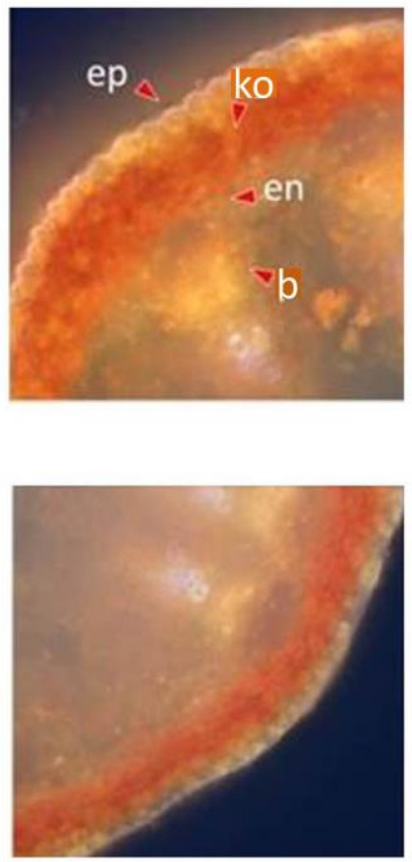

\section{ProUVR8}
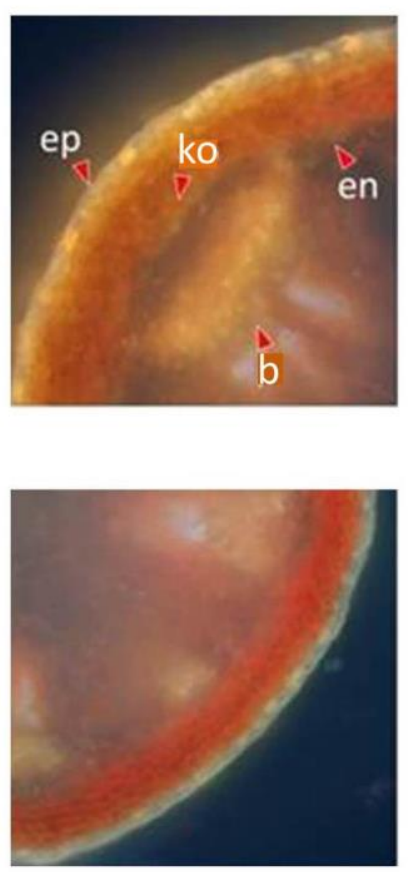

\section{ProSUC2}
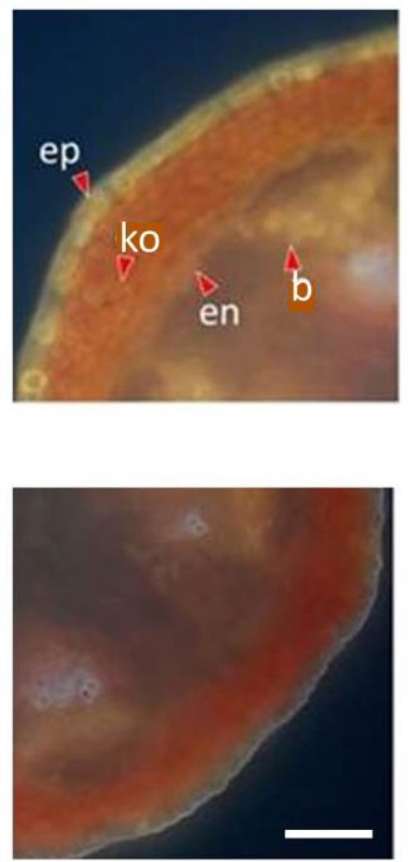

17. ábra: Egyirányú UV-B sugárzásban megfigyelhető UVR8-függő flavonoid felhalmozódás felnőtt növények szárában

Felnőtt növények szárából készített metszetekben DPBA festéssel tettük láthatóvá az egyoldali kiegészítő UV-B sugárzás hatására bekövetkező flavonoid felhalmozódás mintázatát (piros nyilakkal jelölt sárga elszíneződés), amit konfokális mikroszkóppal vizsgáltunk. Rövidítések: ep = epidermisz, ko = kortex, en $=$ endodermisz, $\mathrm{b}=$ bélszövet. A méret vonal $100 \mu \mathrm{m}$-t mutat. 
A CLSM képeken megfigyelt egyenetlen flavonoid felhalmozódást látva meg szerettük volna vizsgálni, hogy a gradiens kialakulását elősegíti-e a flavonoid szintézisben fontos $C H S$ gén egyenlötlen aktivitása a szárban, vagy a megvilágított és árnyékos oldal közötti flavonoid szintkülönbség kizárólag fehérjeszintű folyamatoknak (például helyspecifikus lebontás), vagy a flavonoidok szállításának köszönhető-e. Egyoldali UV-B sugárzás kezelést (1,5 $\mu \mathrm{mol} \mathrm{m}^{-2} \mathrm{~s}^{-1}, 6$ óra) követően vad típusú és $u v r 8$ mutáns növények szárait hosszanti vágással elfeleztük úgy, hogy a megvilágított oldal és az árnyékos oldal között legyen a vágás síkja. A megvilágított és az árnyékos oldali szárfeleket összegyüjtöttük, majd a mintákban meghatároztuk a CHS mRNS mennyiségét. Az eredmények alapján kijelenthetjük, hogy az UVR8-függő CHS génindukció mintázata nagyban (ha nem kizárólagosan) elősegíti a flavonoidok egyenetlen felhalmozódását felnőtt növények szárában (18. ábra).

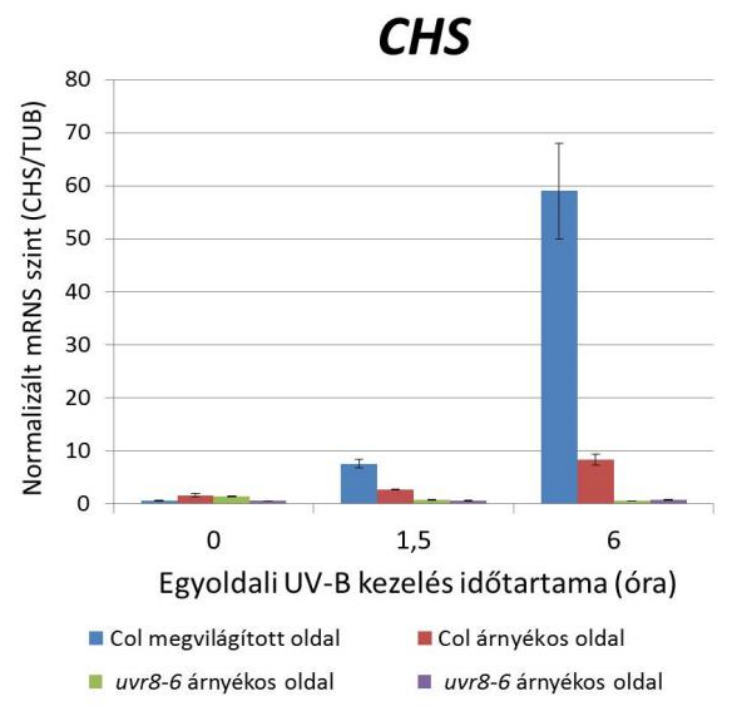

18. ábra: $C H S$ gén aktivitása a felnőtt növény
szárában, egyoldali UV-B kezelést követően

Egyoldali UV-B kezelést követően a virágzati szárak felső harmadát hosszában félbevágtuk, a megvilágított oldali és az árnyékos oldali feleket külön reakciócsövekbe gyüjtöttük, majd RT-PCRrel vizsgáltuk a $C H S$ gén aktivitását vad típusú (Col) és uvr8 mutáns (uvr8-6) növényekben. A mintaszedés időpontjai: közvetlenül az UV-B kezelés előtt (0), UV-B kezelés után 1,5 órával és 6 órával. A hibasávok az átlagok standard hibáját mutatják $(\mathrm{n}=3)$. 


\subsubsection{A morfológiai vizsgálatok eredményeinek összegzése}

Az eddig bemutatott eredmények és megfigyelések alapján táblázatokban összesítettem a vizsgált, UVR8-függő válaszok szöveti függését a könnyebb áttekinthetőség érdekében (2. táblázat, 3. táblázat).

\begin{tabular}{|l|c|c|c|}
\hline & \multicolumn{3}{|c|}{ Csíranövény fenotípusa } \\
\hline & Hipokotil nyúlás gátlás & Sziklevél felület & Flavonoid termelés \\
\hline Col & +++ & +++ & ++ \\
\hline uvr8-6 & - & - & - \\
\hline $\begin{array}{l}\text { ProUVR8:YFP-UVR8 } \\
\text { (epidermisz, mezofill) }\end{array}$ & ++ & +++ & ++ \\
\hline $\begin{array}{l}\text { ProML1:YFP-UVR8 } \\
\text { (epidermisz) }\end{array}$ & ++ & +++ & ++ \\
\hline $\begin{array}{l}\text { ProCAB3:YFP-UVR8 } \\
\text { (mezofill) }\end{array}$ & ++ & - & ++ \\
\hline $\begin{array}{l}\text { ProSUC2:YFP-UVR8 } \\
\text { (mezofill, szállítószövetek) }\end{array}$ & + & - & ++ \\
\hline
\end{tabular}

\section{2. táblázat: A transzgenikus csíranövények komplementációs vizsgálatainak összesítése}

A táblázat a különbözö fenotípus vizsgálatok eredményeit összegzi. A „,” jelek a válaszok mértékét mutatják (+: gyenge válasz, ++: közepes válasz, +++: teljes értékü, erős válasz). A vad típusú (Col) növények teljes értékủ válaszokat mutattak (+++), míg az uvr8 mutánsok egyáltalán nem adtak UVR8 specifikus válaszokat (-). Az első oszlopban jelöltem, hogy az egyes transzgenikus vonalakban mely szövet(ek)ben észleltük az YFP-UVR8 fehérjét.

\begin{tabular}{|c|c|c|c|c|}
\hline & \multicolumn{4}{|c|}{ Felnött növény fenotípusa } \\
\hline & Rozetta méret & Klorofill tartalom & Szárelhajlás & Flavonoid termelés \\
\hline Col & +++ & +++ & +++ & +++ \\
\hline$u v r 8-6$ & - & - & - & $-(+)$ \\
\hline $\begin{array}{l}\text { ProUVR8:YFP-UVR8 } \\
\text { (epidermisz, mezofill) }\end{array}$ & ++ & ++ & +++ & ++ \\
\hline $\begin{array}{l}\text { ProML1:YFP-UVR8 } \\
\text { (epidermisz) }\end{array}$ & ++ & ++ & ++ & ++ \\
\hline $\begin{array}{l}\text { ProCAB3:YFP-UVR8 } \\
\text { (mezofill) }\end{array}$ & $+++(++)$ & $+++(+)$ & +++ & $+++(+)$ \\
\hline $\begin{array}{l}\text { ProSUC2:YFP-UVR8 } \\
\text { (mezofill, szállítószövetek) }\end{array}$ & $+++(+)$ & +++ & ++ & + \\
\hline
\end{tabular}

\section{3. táblázat: Felnőtt transzgenikus növények komplementációs vizsgálatainak összesítése}

A táblázat a különbözö fenotípus vizsgálatok eredményeit összegzi. A „+” jelek a válaszok mértékét mutatják (+: gyenge válasz, ++:közepes válasz, +++: teljes értékű, erős válasz). A vad típusú (Col) növények teljes értékủ válaszokat mutattak $(+++)$, míg az uvr8 mutánsok egyáltalán nem adtak UVR8 specifikus válaszokat (-). A túltermelő fenotípus jelölése: $+++(+)$, az erős túltermelóé: $+++(++)$. Az első oszlopban jelöltem, hogy az egyes transzgenikus vonalak mely szövet(ek)ben termelnek számottevő mennyiségben YFP-UVR8 fehérjét. 


\subsubsection{Az UV-B által indukált HY5 gén indukciója és HY5 fehérje termelődése}

A fény által indukált jelátviteli folyamatok kulcsfontosságú résztvevője a HY5 transzkripciós faktor. A fotomorfogenikus válaszok elindulása jól követhetö a HY5 mRNS szintjének megemelkedésével, aminek következtében a HY5 fehérje felszaporodik a sejtmagban. A HY5 felhalmozódást az aktív UVR8 fotoreceptor is kiváltja, ráadásul UVR8 hiányában a HY5 gén nem indukálódik UV-B sugárzás hatására, ami bizonyítja az UVR8 erre vonatkozó kizárólagos szerepét UV-B-ben (Ulm és mtsai., 2004; Brown és mtsai., 2005; Oravecz és mtsai., 2006; Brown és mtsai., 2009). Annak érdekében, hogy vizsgálni tudjuk a HY5 indukció és a HY5 felhalmozódás szövetspecificitását, új transzgenikus vonalakat állítottunk elö. Az YFP-UVR8-at különbözö szövetekben expresszáló, uvr8 hátterü vonalainkba (ProUVR8, ProML1, ProCAB3) bejuttattuk a ProHY5:HY5-GFP konstrukciót, hogy CLSM segítségével vizsgálhassuk a HY5 fehérje akkumulációját. A fehér fényben nevelt növényekben alacsony szinten volt jelen a HY5-GFP fehérje, míg UV-B megvilágítás hatására elindult a HY5-GFP felhalmozódása azokban a sejtekben, amelyekben volt kimutatható mennyiségü YFP-UVR8 fotoreceptor: a ProUVR8 vonal epidermiszében és mezofilljében, a ProML1 csíranövények epidermiszében, valamint a ProCAB3 vonal mezofilljében (19. ábra). 

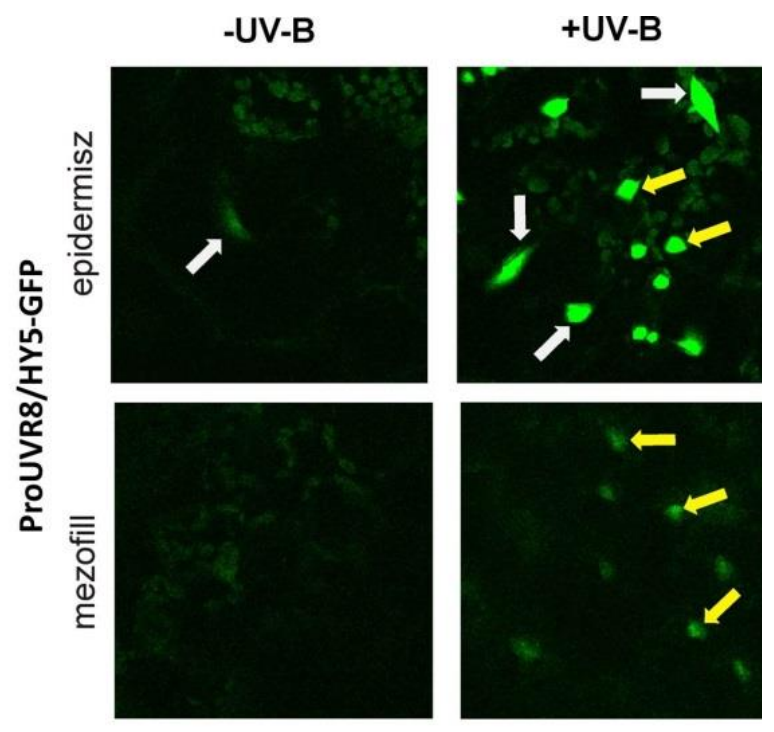

\section{9. ábra: UV-B által kiváltott ProHY5:HY5- GFP kifejeződés a transzgenikus vonalak sziklevelében}

A ProHY5:HY5-GFP konstrukciót bejuttattuk a ProUVR8, ProML1 és a ProCAB3 transzgenikus vonalainkba (az ábrán az így előállított új vonalak jelölése: ProUVR8/HY5-GFP, ProML1/HY5GFP, ProCAB3/HY5-GFP). A HY5-GFP fúziós fehérjét CLSM segítségével vizsgáltuk hétnapos csíranövények sziklevelében az epidermisz, illetve mezofill sejtrétegben, UV-B-vel (1,5 $\mu \mathrm{mol}$ $\left.\mathrm{m}^{-2} \mathrm{~s}^{-1}\right)$ kiegészített fehér fénnyel (+UV-B), illetve UV-B nélküli fehér fénnyel (-UV-B) történő megvilágítást $(16 \mathrm{~h})$ követően. A párban álló (+UV-B) és (-UV-B) képeket egymással megegyező mikroszkóp beállításokat használva készítettük el a jelek összehasonlíthatósága
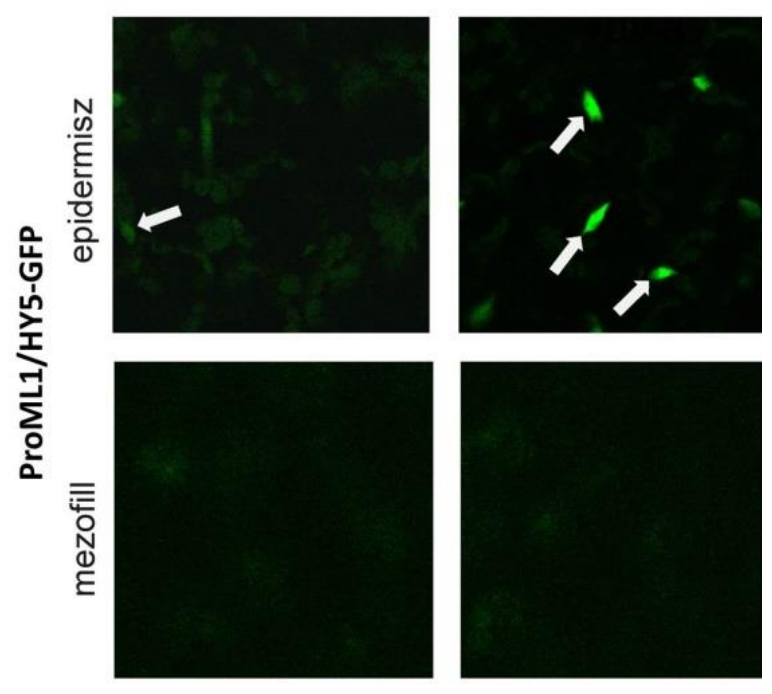
érdekében. A fehér nyilak az epidermisz rétegben kiválasztott sejtmagokat, a sárga nyilak a mezofill rétegben kiválasztott sejtmagokat jelölik. A méret vonal $50 \mu \mathrm{m}-\mathrm{t}$ mutat.
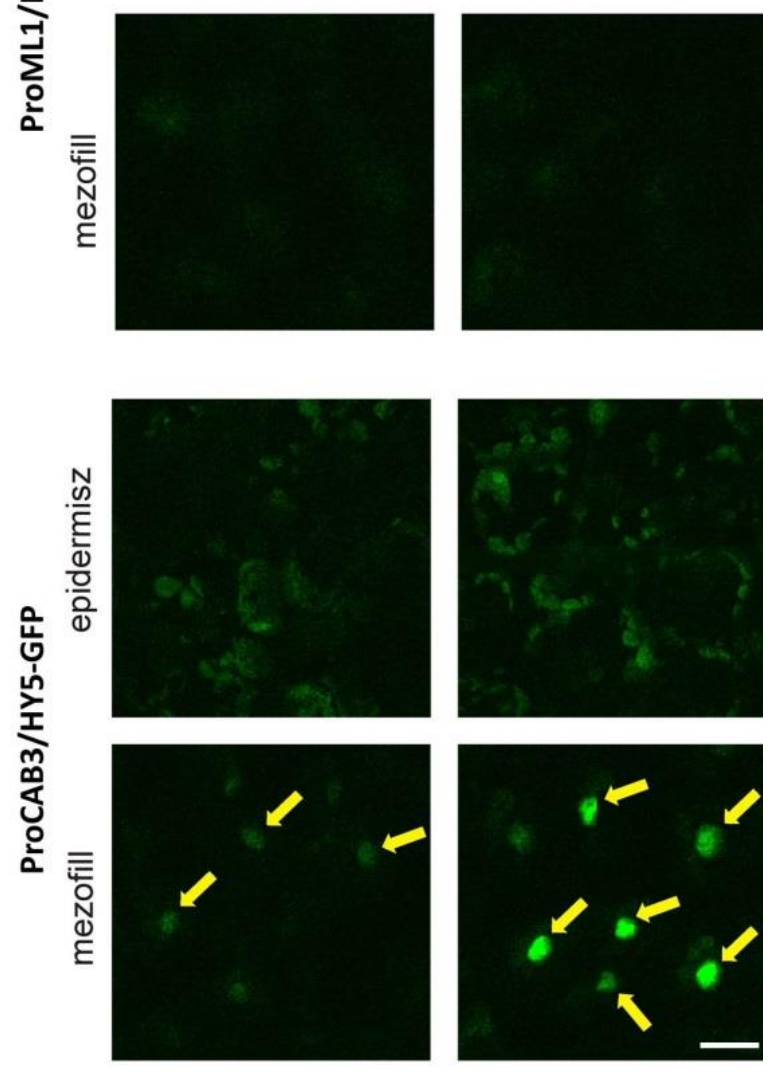

Hasonló eredményeket kaptunk az UVR8-függő HY5 transzkripciójának emelkedésével kapcsolatban is, aminek vizsgálatához újabb növényi vonalakat készítettünk. Az uvr8 mutáns háttérben az YFP-UVR8-at szövetspecifikusan termelő növényeinkbe (ProUVR8, ProML1, 
ProCAB3) bejuttattuk a $H Y 5$ promóter által szabályozott GUS-GFP-NLS riporter gén konstrukciót, hogy a termelödő GUS-GFP-NLS kimérafehérje mennyisége és helye megmutassa, hol és milyen szinten müködött a promóter. Mivel a GUS(-GFP-NLS) fehérjére nincsenek hatással a HY5(-GFP) proteint érintő fehérjeszintű szabályozási folyamatok, így ebben az esetben a detektált GFP jel kizárólag a ProHY5 indukciójának helyét és mértékét tükrözi. A transzkripciós szint emelkedése a HY5 fehérje felhalmozódásához hasonlóan az YFP-UVR8-at tartalmazó sejtekre korlátozódott: a mezofillben a ProUVR8 és a ProCAB3 vonalak, az epidermiszben a ProUVR8 és a ProML1 vonalak adtak GFP jelet (20. ábra). Mindezek alapján arra a következtetésre jutottunk, hogy az UVR8-nak az adott szövetben jelen kell lennie ahhoz, hogy indukálja a HY5 gént, vagyis ebben a folyamatban nincs szövetek közti kommunikáció. 

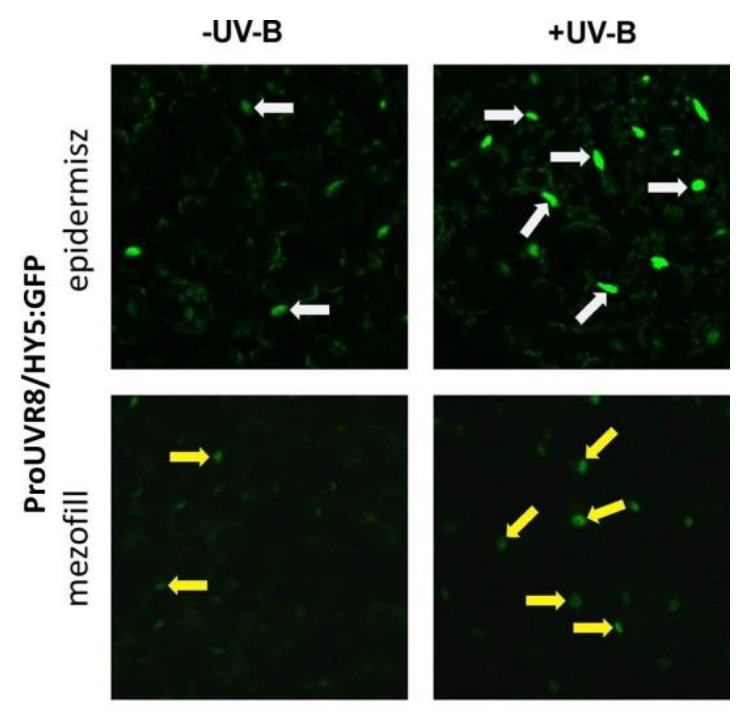

\author{
20. ábra: Az UV-B által kiváltott \\ ProHY5:GUS-GFP-NLS indukció az \\ YFP-UVR8-at különböző szövetekben termelő \\ transzgenikus vonalak sziklevelében
}

A ProHY5:GUS-GFP-NLS transzgént bejuttattuk a ProUVR8, ProML1, ProCAB3 vonalainkba (az így elóállított új vonalak jelölése: ProUVR8/HY5:GFP, ProML1/HY5:GFP, ProCAB3/HY5:GFP).

A GUS-GFP-NLS fúziós proteint CLSM segítségével vizsgáltuk hétnapos csíranövények sziklevelében az epidermisz, illetve mezofill sejtrétegben. Az UV-B-vel $\left(1,5 \mu \mathrm{mol} \mathrm{m}^{-2} \mathrm{~s}^{-1}\right)$ kiegészített fehér fénnyel (+UV-B), illetve UV-B nélküli fehér fénnyel (-UV-B) 16 órán át kezeltük
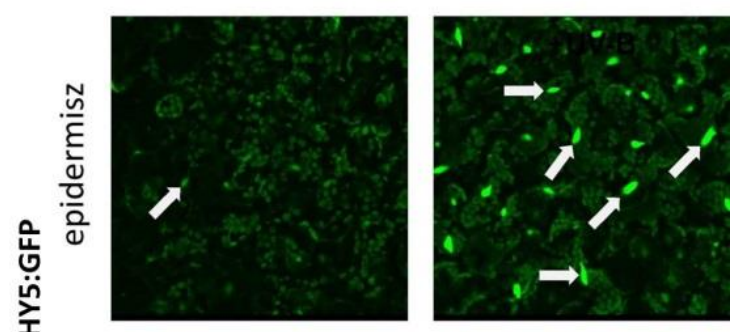
a csíranövényeket a mikroszkópos vizsgálat elött. A párban álló (+UV-B) és (-UV-B) képeket egymással megegyező mikroszkóp beállitásokat használva készítettük el a jelek összehasonlíthatósága érdekében. A fehér nyilak az epidermisz rétegben kiválasztott sejtmagokat, a sárga nyilak a mezofill rétegben kiválasztott sejtmagokat jelölik. A méret vonal $50 \mu \mathrm{m}$-t mutat.
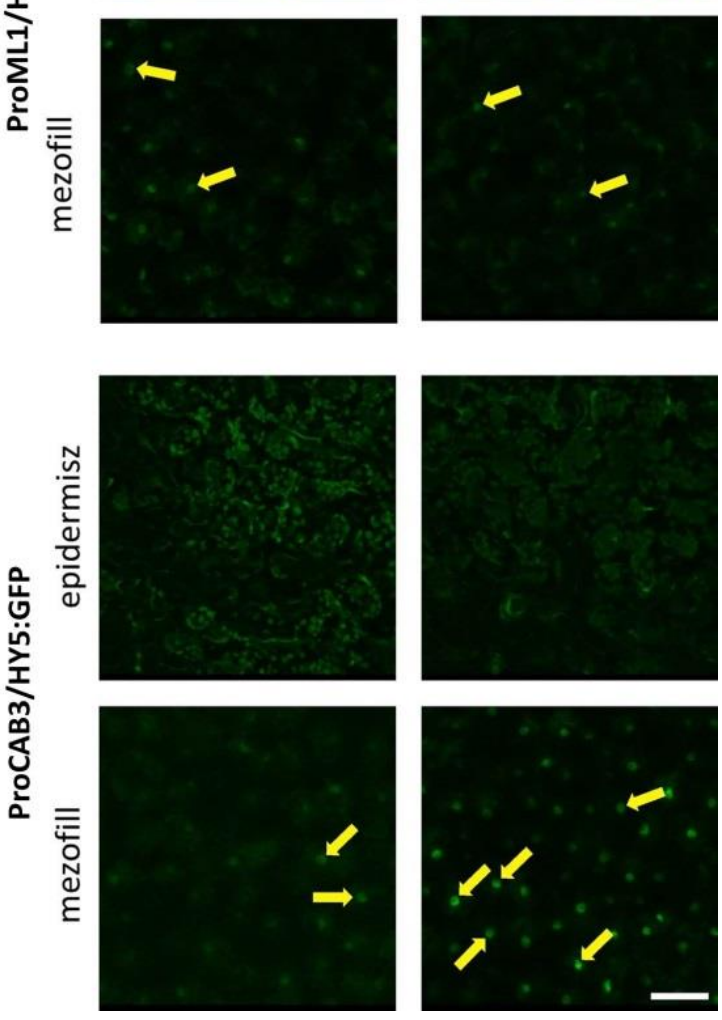

Egyoldali UV-B kezelést követően megvizsgáltuk felnőtt növények szárában is a HY5 és a HYH fehérje termelődésének UVR8 függését, valamint a termelődés helyét. Mutáns hátterü (hy5uvr8 és hy5), ProHY5:HY5-YFP transzgént hordozó növények szárából egész éjszakás UV-B

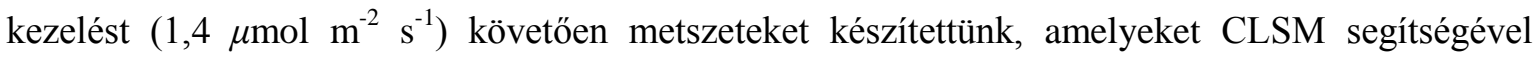


vizsgáltunk. A HY5-YFP mennyisége nőtt az UV-B sugárzás hatására, ráadásul az árnyékoshoz képest szinte kizárólag a szár megvilágított oldalán (21. ábra A). Ezt a megfigyelésünket a HY5YFP jelek intenzitásának számszerüsítése is megerősítette, ráadásul kimutattuk, hogy az UV-B sugárzás által kiváltott HY5-YFP felhalmozódása felnőtt növényben is UVR8-függő, mivel az uvr8 hátterü vonalban egyáltalán nem észleltük HY5-YFP jelenlétét (21. ábra B).

További kísérleteink középpontjában a HY5 homológja, a HYH állt. ProHYH:HYH-YFP transzgént hyh háttérben kifejező növényeket vizsgáltunk, hogy kiderítsük, a HYH felhalmozódása egyoldali UV-B hatására a HY5-éhoz hasonlóan alakul-e. A szármetszetekről készült CLSM felvételeket vizsgálva megállapítottuk, hogy a HYH-YFP fehérje szintén csak a szár UV-B kezelt oldalán detektálható, ami arra utal, hogy a HY5-hoz hasonlóan a HYH felhalmozódását is az UVR8 irányítja (21. ábra C). Ugyanezt a vizsgálatot elvégeztük olyan növényekkel is, melyek a ProHYH:HYH-YFP transzgént hy5hyh dupla hiánymutáns növényekben fejezik ki. Eredményeink azt mutatják, hogy UV-B sugárzásban a HY5 jelenléte nagyban hozzájárul a HYH-YFP fehérje felhalmozódásához, mivel jelentősen több HYH-YFP jelet adó sejtmagot észleltünk a hyh hátterü vonal metszeteiben, mint a hy5hyh hátterű transzgenikus vonalból származókban. A HYH-YFP gradiens a szárban már rövid, 4,5 órás UV-B kezelés hatására is kialakult (21. ábra C). 

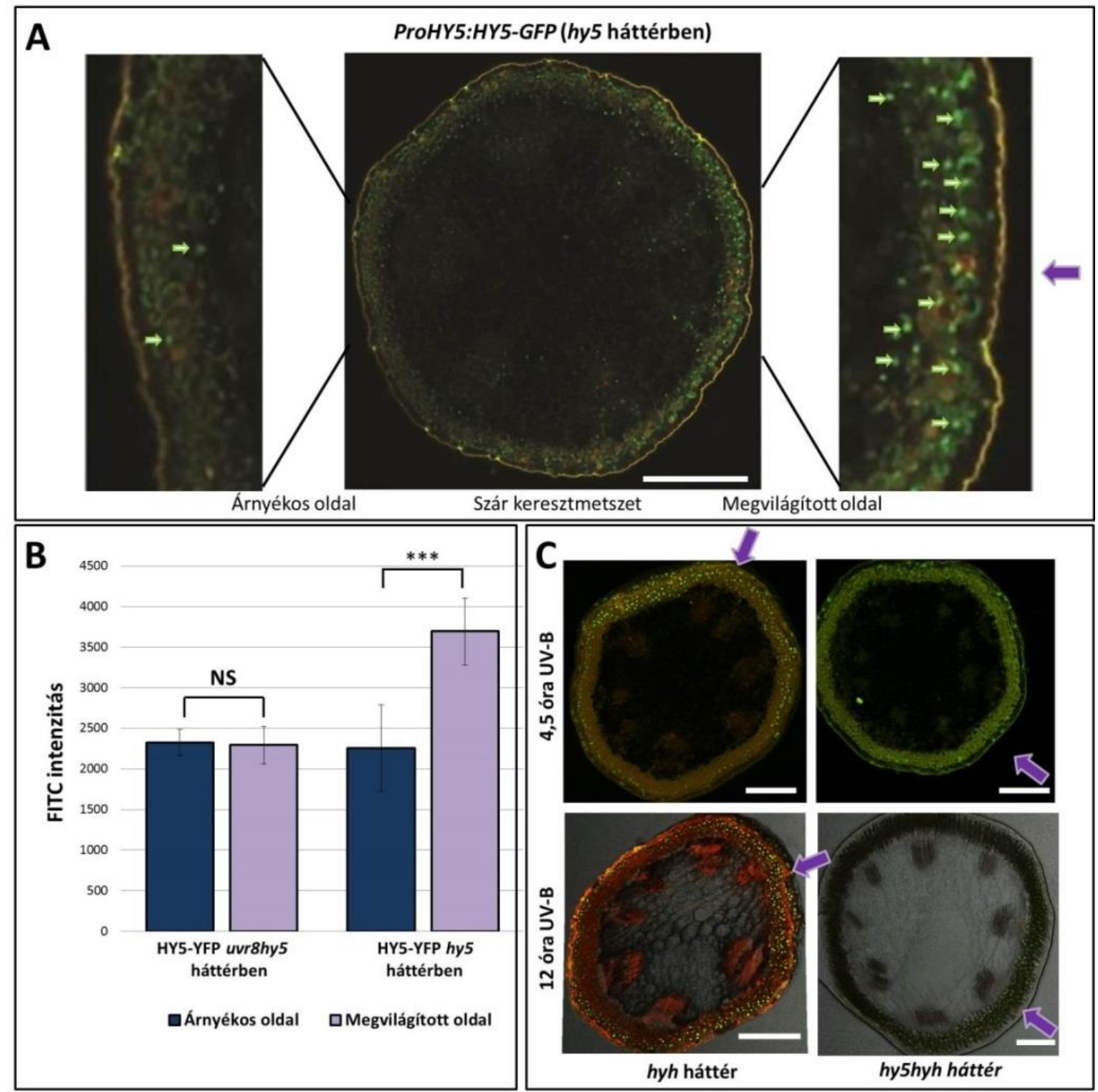

\section{1. ábra: A HY5-YFP és HYH-YFP fehérje eloszlása szárban,} egyirányú UV-B kezelést követően

A) A HY5-YFP jelek eloszlása ProHY5:HY5-YFP transzgént vad típusú háttérben expresszáló növény

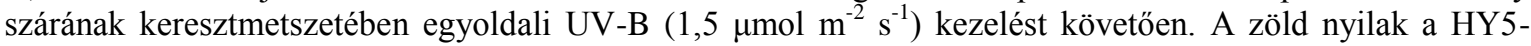
YFP-böl származó jeleket mutatják a kiválasztott sejtmagokban, amiket CLSM-mel detektáltunk. A méret vonal $300 \mu \mathrm{m}-\mathrm{t}$ mutat.

B) A HY5-YFP eloszlásának mintázatát vizsgáltuk hy5 és uvr8hy5 mutáns háttérben HY5:HY5-YFP transzgént expresszáló vonalak szárából készített keresztmetszeteken CLSM-mel, egyoldali UV-B (1,5 $\mu$ mol $\left.\mathrm{m}^{-2} \mathrm{~s}^{-1}\right)$ sugárzást követően. A metszetekröl készült képeken látható HY5-YFP jeleket képelemző szoftverrel számszerüsítettük, a kapott értékeket ábrázoltuk. A mérés jellegéből adódóan a jelet nem adó háttér értéke 2000 és 2500 FiTC intenzitás értékek közé esett, ezt a tartományt az YFP jelre nézve nullának tekintjük. A hibasávok a standard hibát mutatják $(\mathrm{n}>10)$. Szignifikancia szint a Student-féle $t$-próba alapján: ${ }^{*} \mathrm{P}<0.05$, $* * \mathrm{P}<0.01, * * * \mathrm{P}<0.005$, NS: nem szignifikáns, $\mathrm{n}>10$.

C) A korábbiakkal megegyező kísérleti elrendezésben hyh és hy5hyh háttérben ProHYH:HYH-YFP transzgént kifejező vonalakat vizsgáltunk, a metszetekről készített képeken látható HYH-YFP jeleket mutatjuk be. A felső képek az YFP-t detektáló csatornát, az alsó képek a fehér fénnyel átvilágított keresztmetszetek képét és az YFP-t detektáló csatornát egyszerre mutatják be. A lila nyilak az UV-B sugárzás irányát jelölik. A méret vonalok $300 \mu \mathrm{m}$-t mutatnak. 
Mivel a HY5 és a HYH fehérje felhalmozódásának szintje eltér a megvilágított és az árnyékos oldalon, meg szerettük volna vizsgálni, hogy a $H Y 5$ és a $H Y H$ gén indukciója is ezt a mintát követi-e, vagy a gradiens kialakulásáért fehérjeszintű folyamatok felelösek. Egyoldali UV-B

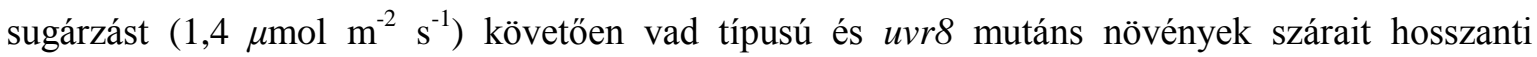
vágással elfeleztük, és a két félben meghatároztuk a $H Y 5$ és a $H Y H$ mRNS mennyiségét. Az UV-B-vel megvilágított oldalról származó szárfelekben a HY5 és HYH mRNS magasabb szinten halmozódott fel, mint az árnyékos oldaliakban. Mindez nem figyelhető meg az uvr8-6 mutáns növények esetében (22. ábra). Ezek az eredmények bizonyítják, hogy az UVR8 transzkripciós szinten is elősegíti a szárakban megfigyelhető HY5 és HYH gradiens kialakulását.
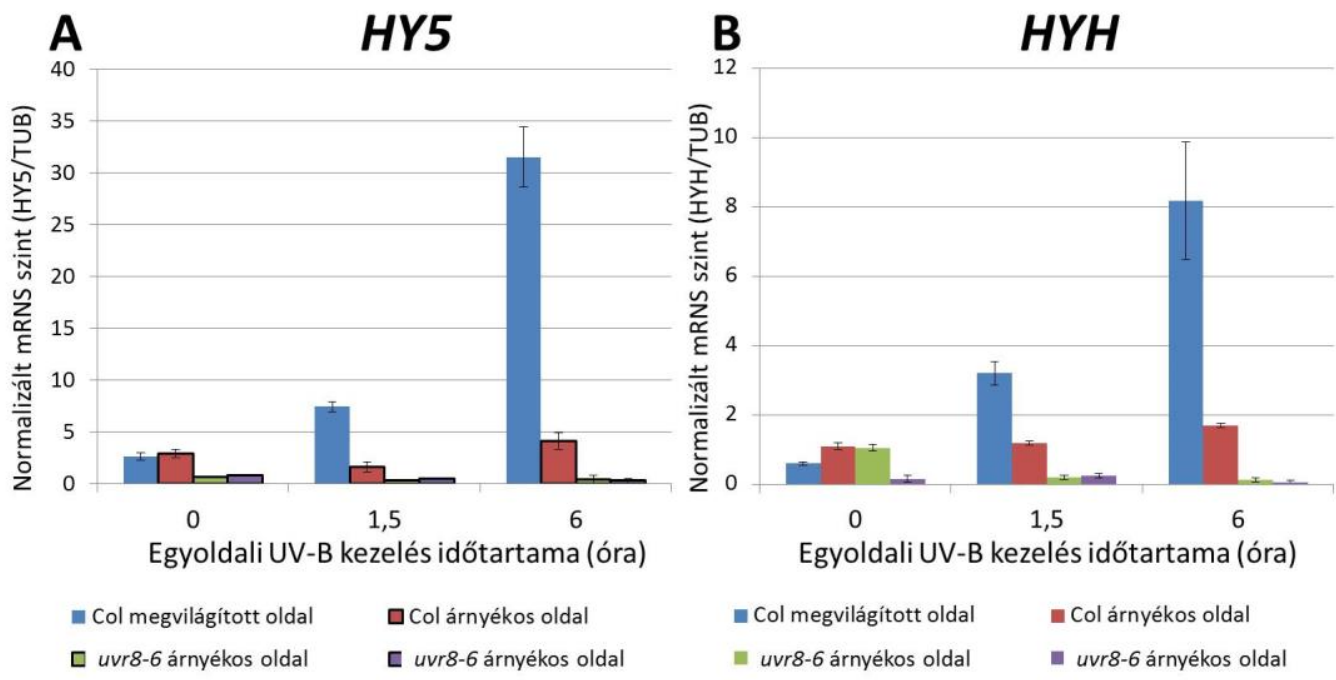

22. ábra: A HY5 és HYH gén aktivitása egyoldali UV-B sugárzást követően felnőtt növények szárában

Egyoldali UV-B kezelést követően a virágzati szárak felső harmadát hosszában félbevágtuk, a megvilágított oldali és az árnyékos oldali feleket külön gyüjtöttük, majd RT-PCR módszerrel vizsgáltuk a HY5 (A) és a $H Y H$ (B) mRNS felhalmozódását vad típusú (Col) és uvr8 mutáns (uvr8-6) növényekben. A mintaszedés időpontjai: közvetlenül az UV-B kezelés elött (0), UV-B kezelés után 1,5 órával és 6 órával. A hibasávok az átlagok standard hibáját mutatják $(\mathrm{n}=3)$.

\subsubsection{UV-B indukált HY5-függő és HY5-független gének transzkripciója}

Az EARLY LIGHT INDUCED PROTEIN 2 (ELIP2) fehérje a tilakoid membránok fotoprotekciójában játszik szerepet, ezért az UV-B sugárzás hatására megnövekedő szintje a fotoszintetikus apparátus védelmét szolgálja (Hutin és mtsai., 2003). Korábbi munkákban leírták, hogy az UV-B sugárzás serkenti az ELIP2 gén müködését, és ehhez szükség van UVR8 és HY5 fehérjére (Ulm és mtsai., 2004; Oravecz és mtsai., 2006; Favory és mtsai., 2009; Fehér és mtsai., 2011). Saját kísérleti rendszerünkben kapott eredményeink ezeket a megfigyeléseket megerősítették (23. ábra). 


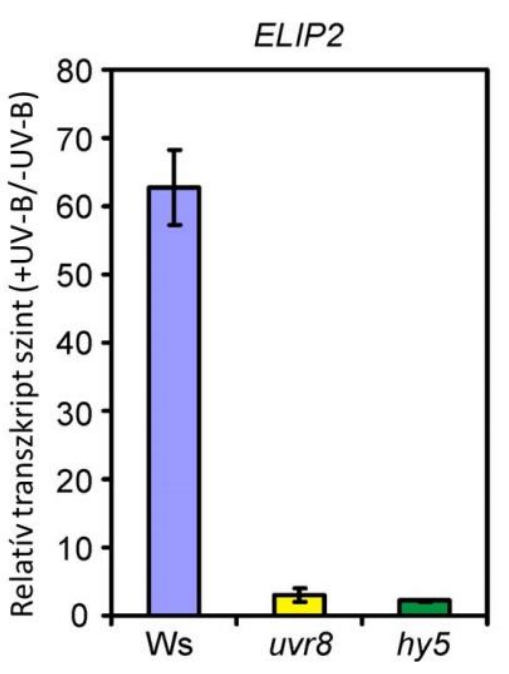

\section{3. ábra: Az ELIP2 gén transzkripciójának UVR8 általi indukciója és HY5-függése}

Hétnapos csíranövényeket UV-B-vel kiegészített fehér fénnyel világítottunk meg 90 percig. A növények felét WG305 filterrel (+UV-B), másik felét WG385 filterrel (-UV-B) takartuk le. Ezután RT-PCR módszerrel meghatároztuk az ELIP2 mRNS szintjét. A relatív értékeket (+UV-B/-UVB) mutatjuk be az ábrán. A hibasávok az átlagok standard hibáját mutatják $(n=3)$. Jelölések: Ws $=$ Wassilewskija vad típus; $u v r 8=u v r 8-7$ mutáns; hy5 = hy5-ks50 mutáns (mindegyik Ws ökotípusban).

Miután megfigyeltük, hogy a HY5 UVR8-től függő expresszió-indukciója szövetspecifikus úton müködik, meg szerettük volna vizsgálni, hogy az UVR8 által elindított jelátviteli utak HY5 után következő lépései is szövetautonómok-e. Ennek eldöntésére a ProELIP2:GUS-GFP-NLS transzgént bejuttattuk a ProUVR8, ProML1 és a ProCAB3 vonalainkba, a vizsgálatokat pedig CLSM-mel végeztük. A ProELIP2 aktivitás fehér fényben alacsony, ezt az UV-B viszont drasztikusan megemeli, de csak azokban a sejtekben, amelyek tartalmaznak detektálható mennyiségű YFP-UVR8 fehérjét. A ProUVR8 vonalunk epidermiszében és a mezofill szöveteiben egyaránt fokozódott a ProELIP2 múködése, az epidermális YFP-UVR8 kifejeződést mutató ProML1 növényekben csak az epidermiszben, míg a mezofillben YFP-UVR8-at tartalmazó ProCAB3 növényekben pedig csak a mezofillben láttunk UV-B hatására megemelkedett ProELIP2 aktivitást (23. ábra). Az eredmények alapján az UVR8 a HY5-függő ELIP2 kifejeződést szövetspecifikusan szabályozza, nem tapasztaltunk szövetek közötti jelterjedést. 


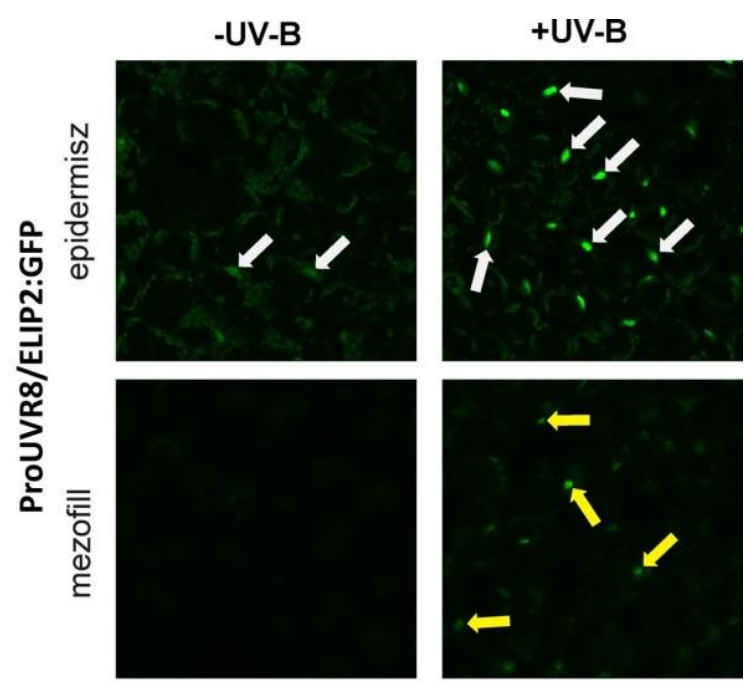

\section{4. ábra: UV-B által kiváltott ProELIP2:GUS-GFP-NLS kifejeződés a transzgenikus növények sziklevelében}

A ProELIP2:GUS-GFP-NLS konstrukciót bejuttattuk a ProUVR8, ProML1 és ProCAB3 transzgenikus vonalainkba. (Az új vonalak jelölése: ProUVR8/ELIP2:GUS, ProML1/ELIP2:GUS, ProCAB3/ELIP2:GUS.) A GUS-GFP-NLS fúziós protein előfordulását CLSM-mel vizsgáltuk hétnapos csíranövények sziklevelében az epidermisz, illetve a mezofill sejtrétegben. A csíranövényeket UV-B-vel kiegészített fehér fénnyel (+UV-B), illetve UV-B nélküli fehér fénnyel (-UV-B) kezeltük 16 órán át a mikroszkópos vizsgálat megkezdése előtt. A párban álló (+UV-B és -UV-B) képeket

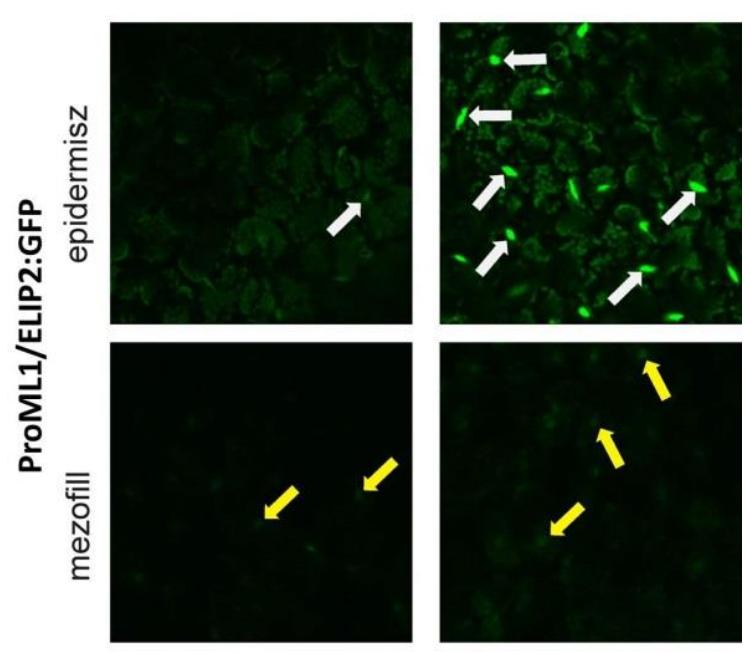
egymással megegyező mikroszkóp beállításokat használva készítettük el a jelek összehasonlíthatósága érdekében. A fehér nyilak az epidermisz rétegben kiválasztott sejtmagokat, a sárga nyilak a mezofill rétegben kiválasztott sejtmagokat jelölik. A méret vonal $50 \mu \mathrm{m}$-t mutat.

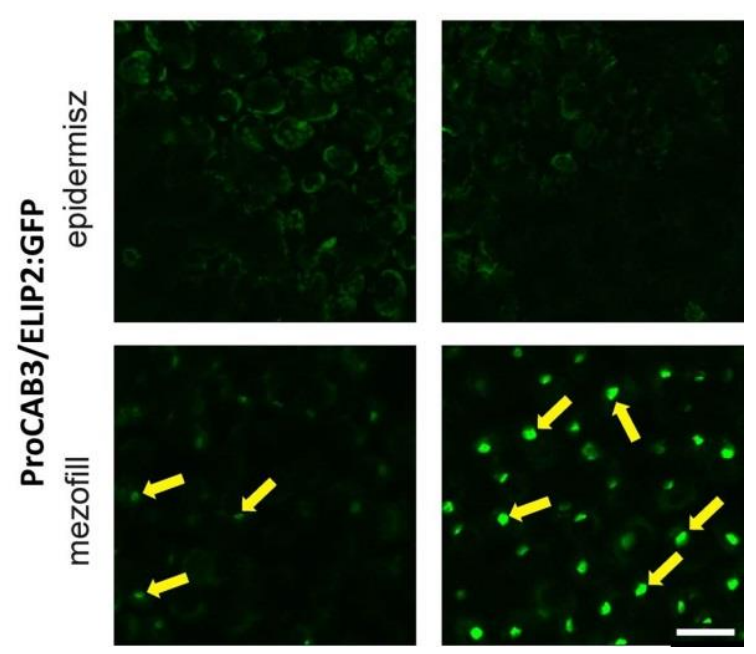

A PSEUDO-RESPONSE REGULATOR 9 (PRR9) a növényi cirkadián óra eleme. Kifejeződése mindamellett, hogy napi ritmust mutat, UV-B sugárzás által is szabályozott (Nakamichi és mtsai., 2005; Fehér és mtsai., 2011). Promóterének aktivitása UV-B hatására megemelkedik, ez a jelenség függ az UVR8-tól, de független a HY5-tól (24. ábra). 


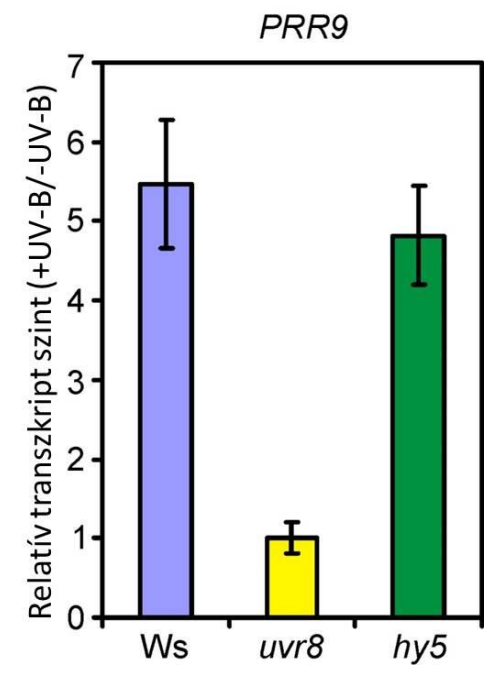

\section{5. ábra: Az PRR9 gén transzkripciójának UVR8 általi indukciója és HY5-függése}

Hétnapos csíranövényeket UV-B-vel kiegészített fehér fénnyel világítottunk meg 90 percig. A növények felét WG305 filterrel (+UV-B), másik felét WG385 filterrel (-UV-B) takartuk le. Ezután meghatároztuk a PRR9 mRNS mennyiségét. A relatív értékeket (+UV-B/-UV-B) mutatjuk be az ábrán. Ws $=$ Wassilewskija vad típus; $u v r 8=u v r 8-7$ mutáns; hy5 = hy5-ks50 mutáns (mind Ws ökotípusban). A hibasávok az átlagok standard hibáját mutatják $(\mathrm{n}=3)$.

A HY5 és az ELIP2 promótereivel ellentétben a ProPRR9 aktívan müködött a fehér fényben nevelt transzgenikus csíranövények szikleveleinek mezofill sejtjeiben. Ezt a PRR9 aktivitást az UV-B sugárzás számottevően megemelte, de csak a mezofill sejtekben, ha azok tartalmaztak kimutatható mennyiségü YFP-UVR8 fehérjét: ProUVR8 és ProCAB3 vonalainkban a mezofillben erőteljes aktivitás-emelkedést figyeltünk meg (26. ábra). Érdekes, hogy nem tapasztaltuk sem a ProML1, sem a ProUVR8 vonal epidermiszében a ProPRR9 promóter kimutatható mértékü aktivitás emelkedését, annak ellenére sem, hogy ezekben a növényekben van kimutatható mennyiségű epidermális YFP-UVR8. Ezek a megállapítások tovább erősítik a korábbi eredményeket, miszerint az UV-B hatására UVR8 által vezérelt jelátviteli utak lehetnek szövetspecifikusak, ráadásul az egyes jelátviteli útvonalakat egyéb faktorok is befolyásolhatják egyedi müködési módjaik által. 

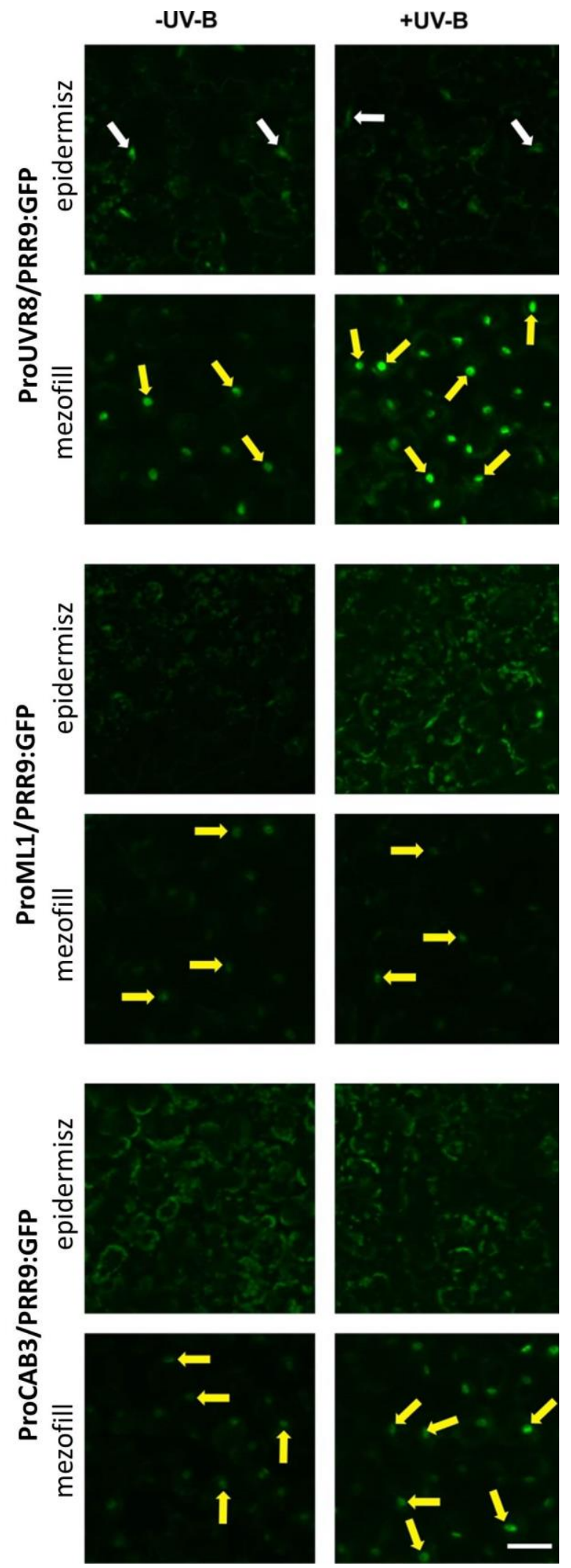

ProPRR9:GUS-GFP-NLS indukció az YFP-

UVR8-at különböző szövetekben termelö

transzgenikus vonalak sziklevelében

A ProPRR9:GUS-GFP-NLS konstrukciót bejuttattuk a ProUVR8, ProML1 és ProCAB3 transzgenikus vonalainkba. (A vonalak jelölése: ProUVR8/PRR9:GFP, ProML1/PRR9:GFP, ProCAB3/PRR9:GFP.) A GUS-GFP-NLS fúziós proteint CLSM-mel vizsgáltuk hétnapos csíranövények sziklevelében az epidermisz, illetve a mezofill sejtrétegben. A csíranövényeket UV-B-vel kiegészített fehér fénnyel (+UV-B), illetve UV-B nélküli fehér fénnyel (-UV-B) kezeltük 16 órán át a mikroszkópos vizsgálat megkezdése előtt. A párban álló (+UV-B és -UVB) képeket egymással megegyező mikroszkóp beállításokat használva készítettük el a jelek összehasonlíthatósága érdekében. A fehér nyilak az epidermisz rétegben kiválasztott sejtmagokat, a sárga nyilak a mezofill rétegben kiválasztott sejtmagokat jelölik. A méret vonal $75 \mu \mathrm{m}$-t mutat. 


\section{EREDMÉNYEK ÉRTÉKELÉSE}

\subsection{Az UVR8 fehérje előfordulása különbözö szövetekben}

Munkánk során egyik célunk az volt, hogy megfigyeljük az UVR8 fotoreceptor eloszlását a különböző növényi szövetekben. A ProUVR8:YFP-UVR8 transzgént $u v r 8$ mutáns háttérben expresszáló vonalunkban (ProUVR8) az YFP-t CLSM-el vizsgálva megállapítottuk, hogy az UVR8 fotoreceptor detektálható szinten megtalálható az UV-B sugárzásnak kitett csíranövények epidermiszében és epidermisz alatti sejtjeiben (mezofill/szubepidermális sejtek), a hipokotilban és a sziklevelekben egyaránt (7. ábra A-C, 8. ábra A-C). Mivel a szállítószövetekben nem találtunk kimutatható mennyiségű YFP-UVR8 fehérjét, valószínüsítjük, hogy az ott esetlegesen található UVR8 fotoreceptornak nincs fontos szerepe az UV-B által kiváltott jelátviteli folyamatok elindításában. Meg kell azonban jegyeznünk, hogy az általunk használt ProUVR8:YFP-UVR8 transzgenikus vonal az endogén UVR8 mennyiséghez képest alacsonyabb szinten termeli az YFP-UVR8 fehérjét (10. ábra A), emiatt nem zárhatjuk ki annak a lehetőségét, hogy az endogén UVR8 előfordulhat a szállítószövetekben is. Ha ez így is van, szerepe a fotomorfogenezis irányításában nem jelentős. Ezt támasztja alá az is, hogy az UV-B sugarak alig jutnak el a növények mélyebb szöveti rétegeibe (Day és mtsai., 1993).

\subsection{A különböző szövetekben kifejezett UVR8 funkciói}

Az YFP-UVR8 fúziós fehérje nem csak arra alkalmas, hogy az YFP jelölés révén láthatóvá váljon az UVR8 elhelyezkedése, hanem használható az uvr8 mutáns fenotípus helyreállítási vizsgálatok során is, mivel ez a protein aktív fotoreceptorként müködik a riporter gént különböző szövetekben termelő növényeinkben (11. ábra). Az YFP-UVR8-at kifejező vonalaink tehát alkalmasak arra, hogy az UVR8 különböző, szöveti elhelyezkedésétől függő funkcióit vizsgálni tudjuk.

\subsubsection{Csíranövényeken vizsgált fotomorfogenikus}

\section{UV-B-válaszok}

Ezen kísérletek során az UV-B kezelésnek kitett csíranövényekkel kapcsolatos legismertebb fotomorfogenikus válaszokat, vagyis a hipokotil megnyúlás gátlását, valamint a 
sziklevelek méretének növekedését vizsgáltuk meg. Az YFP-UVR8 fehérjét epidermiszben termelő ProML1 csíranövények UV-B kezelést követően a vad típussal megegyezö méretü sziklevelekkel rendelkeztek, de a hipokotil megnyúlás gátlásának mértéke elmaradt a vad típusnál tapasztalttól (11. ábra). A ProCAB3 vonalban az epidermisz alatti sejtekben (mezofill/szubepidermális sejtek) magas szinten termelődik az YFP-UVR8 fehérje, ez a vonal csak részleges hipokotil megnyúlás gátlás reakciót mutatott, a sziklevél növekedési válasza pedig nagyon gyenge volt (11. ábra). Ezek az eredmények arra utalnak, hogy bár a mezofillben található UVR8 is hozzájárul a hipokotil megnyúlás gátlásához, az epidermiszben müködő UVR8 fotoreceptor szerepe lényegesen hangsúlyosabb. Ezt az is alátámasztja, hogy a ProML1 vonal erőteljesebb válaszához sokkal kevesebb YFP-UVR8 elég volt, mint amennyit a ProCAB3 vonal a mezofill rétegeiben termel, ami a fotoreceptor szöveti elhelyezkedésének fontosságát mutatja.

A hipokotil válasszal ellentétben a sziklevél UV-B indukált növekedéséhez kizárólag az epidermális UVR8 járul hozzá: azok a vonalak, amelyek nem termelnek YFP-UVR8-at az epidermiszükben (ProCAB3, ProSUC2), az uvr8 mutáns növényekre jellemző fenotípust mutatták (11. ábra).

A ProSUC2 növények UV-B hatására nagyon gyenge hipokotil, illetve sziklevél növekedési választ adtak annak ellenére, hogy például az erős választ adó ProML1 vonalhoz képest magas szinten termelik az YFP-UVR8 fehérjét (10. ábra A, 11. ábra). Mivel a ProSUC2 promóter a szállítószöveteken kívül az epidermisz alatti sejtrétegben is aktívnak bizonyult (7. ábra J-L, 8. ábra J-L), még a gyenge hipokotilválasz is valószínúleg csak az ott található YFP-UVR8 fotoreceptornak köszönhető, a szállítószövetben előforduló UVR8 szerepe elhanyagolhatónak tünik a csíranövények növekedési folyamatainak szabályozásában (11. ábra).

Eredményeink arra utalnak, hogy a csíranövények UV-B sugárzás érzékelésében az epidermiszben müködő UVR8 játszik kiemelkedő szerepet, amihez, bár kisebb mértékben, de hozzájárul az epidermisz alatti sejtek csoportjában található UVR8 is (11. ábra A). Az epidermális UVR8 kiemelt szerepét erősíti, hogy az UV-B sugárzásnak csak nagyon kis hányada képes a növények mélyebb rétegeibe eljutni (Day és mtsai., 1993), ami alapján nem meglepö, hogy az UV-B sugarak legfontosabb érzékelési helye a növények felszíne, illetve a felszínhez legközelebbi rétegek. Több korábbi eredmény is arra utal, hogy a hipokotil megnyúlás szabályozásában az epidermiszben zajló fényérzékelésnek kiemelt szerepe van, ezt korábban a phyA, a phyB és a brasszinoszteroid jelátvitellel kapcsolatban is megfigyelték (Endo és mtsai., 2005; SavaldiGoldstein, Peto, és Chory, 2007; Kim és mtsai., 2016; Kirchenbauer és mtsai., 2016). Eredményeink összhangban vannak azokkal a megfigyelésekkel is, melyek szerint a phyA és a brasszinoszteroidok epidermális jelátvitele önmagában kevés ahhoz, hogy teljes mértékü növekedési válaszokat váltson ki (Savaldi-Goldstein és mtsai., 2007; Kirchenbauer és mtsai., 2016). A szövetek közötti együttmüködés azonban nem egyenlő mértékü minden folyamatra nézve: a hipokotil megnyúlás gátlását közösen irányítja az epidermiszben és a szubepidermális rétegekben 
található UVR8 (11. ábra A), a sziklevelek méretének szabályozásában viszont szinte kizárólagos az epidermiszben előforduló UVR8 szerepe (11. ábra B), így az utóbbi szabályozási módot nem csak részfolyamataiban, hanem teljes egészében is szövetautonómnak tekinthetjük.

\subsubsection{Felnőtt növényekben vizsgált fotomorfogenikus és akklimációs folyamatok}

Olyan kísérleti rendszert hoztunk létre, amely lehetővé teszi az UVR8 által irányított fejlődési folyamatok és akklimációs válaszok megfigyelését felnőtt növényekben. Fehér fényben (kontroll) minden vizsgált növény teljesen egyformán fejlödött, ezzel szemben a gyenge UV-B sugárzással kiegészített fehér fényben nőtt vad típusú, illetve az YFP-UVR8-at kifejező transzgenikus egyedek tőlevélrózsája (rozettája) kisebb volt, mint az uvr8 mutánsé. Leginkább a ProCAB3, de kisebb mértékben a ProSUC2 növények is, UVR8 túltermelő fenotípust mutattak, mivel rozettájuk jóval kisebb volt a vad típusú növényekénél (12. ábra A, B).

$\mathrm{Az}$ előbbi eredmények nagyon hasonlítanak az erős kiegészítő UV-B megvilágításban végzett akklimációs kísérletek eredményeihez, amelyben olyan UV-B intenzitást alkalmaztunk, amihez a vad típusú növények még képesek voltak alkalmazkodni, míg az uvr8 mutáns növények elhaltak. Mindegyik transzgenikus vonalunk túlélte az erős UV-B megvilágítást. Azok a vonalak, amelyek termelnek epidermiszükben YFP-UVR8-at (ProUVR8, ProML1), a vad típusú növényre hasonlítottak, a ProCAB3 és ProSUC2 növények rozettái pedig erős fényben is az UVR8-at túltermelő növényekre jellemző fenotípust mutatták (12. ábra). Ennek oka az lehet, hogy a ProCAB3 és ProSUC2 növények valóban nagy mennyiségű YFP-UVR8 fehérjét termelnek a mezofill és kortex szöveteikben (13. ábra). Eredményeink alapján valószínü, hogy az UV-B elleni védekezésben felnőtt növényekben már nem az epidermiszben, hanem a mezofillben/kortexben található UVR8 játszik fontosabb szerepet. Vonalaink fenotípusának összehasonlítása alapján (az általuk termelt YFP-UVR8 mennyiségeket figyelembe véve) az UVR8 mennyisége képes befolyásolni az UV-B-válaszok erősségét, bár valószínűleg különböző szövetekben eltérő mértékben: tágabb értelemben az összesített UVR8 mennyiség valószínüleg hatással van a válaszok intenzitására. Ezt a feltételezést támasztja alá, hogy az UVR8-at folyamatosan túltermelő növényeken jól látható és kimutatható fenotípus változásokat lehet megfigyelni (Favory és mtsai., 2009). Ráadásul ez a jelenség nem kizárólag az UVR8 fotoreceptorra jellemző, például a phyB-t folyamatosan túltermelő felnőtt növények is mutatnak a megemelkedett fotoreceptor szinthez köthető fenotípus változásokat (Hajdu és mtsai., 2015). A mezofill/kortex szövetekben előforduló UVR8 kiemelt szerepére utal továbbá, hogy felnőtt növényben ezek a szövetek az epidermiszhez hasonlítva sokkal nagyobb tömegben vannak jelen, emiatt ott több UVR8 halmozódhat fel. Érdemes megjegyezni azt is, hogy a mezofillben/kortexben található UVR8 mellett a sokkal kisebb mennyiségü epidermális UVR8 jelenléte is szükséges a rozetták megfelelő fejlődéséhez. 
A mélyebb szövetekbe az UV-B sugárzás kevésbé jut el, ennek ellenére ott is fontos az UVR8 jelenléte, ugyanis az akklimációs válaszreakcióknak éppen akkor van nagy jelentőségük, amikor erősödik az UV-B kitettség, emiatt a mélyebb rétegekbe is eljut a válaszok erősítéséhez szükséges erősségü UV-B sugárzás: az ilyen jellegü reakciókra éppen erős UV-B sugárzásban van szükség.

Eredményeink alapján tehát a különböző szövetekben az UVR8 által elindított folyamatok nagy valószínűséggel végül összeadódva fejtik ki hatásukat a fotomorfogenikus és akklimációs UV-B-válaszokra. Ez nem szükségszerüen jelenti azt, hogy az adott szövetből elinduló jelátviteli lánc váltaná ki más szövetekben is a jelátvitel elindulását, éppen ellenkezőleg: a jelátviteli láncok különböző szövetekben egyszerre elindulva, egymás mellett futva (esetleg eltérő arányban) fejtik ki hatásukat, amelyek a folyamatsor végén összeadódva eredményezik a megfelelő UV-B-választ. Míg a csíranövények fotomorfogenikus válaszaiban kevéssé hangsúlyos, addig a felnőtt növények akklimációs folyamataiban kiemelt szerepet játszik a mezofillben/kortexben található UVR8. Ezt az is alátámasztja, hogy megemelkedett UV-B sugárzás alatt a fotoszintetikus aktivitás fenntartásához is fontos a mezofillben lévő UVR8 (Davey és mtsai., 2012), valószínűleg azért, mert képes szabályozni a fotoszintetikus PSII reakciócentrum D1 és D2 fehérjéinek szintjét, ahogy azt megfigyelték Chlamydomonasban (Tilbrook és mtsai., 2013). Így tehát az UVR8 azokban a sejtekben képes ilyen irányú szabályozásra, amikben van kloroplasztisz, vagyis az epidermisz sejtjeiben nem. Frissen közölt eredmények molekuláris szinten is megerősítik az UVR8 szerepét a fotoszintetikus aktivitás fokozásában. Kiderült, hogy paradicsomban (Solanum lycopesicum) az UVR8 a GOLDEN-LIKE 2 (SIGLK2) transzkripciós faktor szintjének megemelésével képes növelni a kloroplasztok számát és a klorofill mennyiségét (Li és mtsai., 2018).

A ProSUC2 növények válaszainak elemzésekor nem szabad figyelmen kívül hagynunk, hogy CLSM felvételeink alapján a ProSUC2 promóter nem csak a szállítószövetekben aktív, hanem a mezofillben is (7. ábra J-L, 8. ábra J-L). Emiatt nem állíthatjuk, hogy a ProSUC2 vonal válaszai kizárólag a szállítószövetekben előforduló YFP-UVR8 fotoreceptornak voltak köszönhetőek, sokkal valószínübb, hogy ezekért a mezofillben elöforduló YFP-UVR8 volt a felelős. A szállítószövetekben előforduló UVR8 esetleges hatásait más módszerrel tovább kell vizsgálnunk.

\subsubsection{Fototropikus elhajlás UV-B sugárzás irányába}

Korábban kimutatták, hogy a csíranövények hipokotilja az egyoldali UV-B sugárzás forrása felé elhajlik, ezt a folyamatot ráadásul két külön jelátviteli rendszer szabályozza: a fototropinok által irányított gyors, valamint az UVR8-függő lassabb jelátviteli út (Vandenbussche és mtsai., 2014). Érdekes módon, annak ellenére, hogy csíranövényekben a fototropinok elsődleges szerepet játszanak az elhajlás szabályozásában, eredményeink alapján a felnőtt növényekben 
a fototropinok szerepe elhanyagolható (14. ábra). Ebben a fejlódési szakaszban az UVR8-é a főszerep, de minimális szinten a fototropinok is funkcionálnak. Ez akkor figyelhető meg, ha nincs jelen az UVR8 a rendszerben: míg az $u v r 8$ növények minimálisan elhajlanak (ezért felelösek a fototropinok), a phot1phot2amiUVR8 mutáns növények teljes mértékben érzéketlenek az egyirányú UV-B kezelésre (14. ábra). Ez azt is bizonyítja, hogy ezen a három fotoreceptoron kívül más faktor nem képes kiváltani mérhető szárelhajlást UV-B hatására.

Szövetspecificitásra irányuló kísérleteink során azt találtuk, hogy az elhajlás kiváltásában az epidermiszben található YFP-UVR8 fontos szerepet játszik, mivel a ProML1 vonalunk, dacára az alacsony szintü YFP-UVR8 expressziós szintjének, jól mérhető elhajlást mutat az UV-B sugárzás felé (13. ábra, 15. ábra). Figyelembe véve, hogy ez a szövet van leginkább kitéve a fénynek, ezáltal az UV-B sugárzásnak is, az eredmény nem meglepö. A ProCAB3 vonalunk a vad típushoz hasonló mértékủ választ adott, ami azt támasztja alá, hogy a mezofillben/kortexben található UVR8 is nagyban hozzájárul a szár elhajlásához (15. ábra). A ProUVR8 válasza egyenértékü a ProCAB3 növényekével, annak ellenére is, hogy jóval kevesebb össz-YFP-UVR8-at termel, mint a ProCAB3 növények (13. ábra, 15. ábra). Ez arra utalhat, hogy az epidermiszben található kevés UVR8 is nagyon effektív, aminek hatásához a mezofillben/kortexben található UVR8 is hozzájárul. Ezek az eredmények önmagukban azonban csak erösítik az előző feltevéseket, de nem bizonyítják, ugyanis nagy valószínúséggel az elhajlásválasz a korábban említett vonalak (Col, ProCAB3 és ProUVR8) által mutatott szinten tetőzik. Ez igen valószínü, tekintve, hogy a túlzott elhajlás nem lenne kedvező a növényeknek. Emiatt nem tudhatjuk pontosan, hogy az egyforma, vad típussal megegyező választ adó vonalakban található YFP-UVR8 mennyisége meghaladta-e a maximális válaszhoz szükséges fehérje szinteket az egyes szövet(ek)ben, vagy éppen csak elérte azt. Ennek tükrében akár az is előfordulhat, hogy a ProCAB3 kortexében található YFP-UVR8-hoz képest sokkal kevesebb kortikális YFP-UVR8 is elegendő lenne a vad típushoz mérhető elhajlás kiváltásához. A vad típusnál megfigyelhető válasz telítettségét az is alátámasztja, hogy a ProUVR8 és a vad típusú növények egyforma választ adtak annak ellenére, hogy a vad típusú növényben jelentősen több UVR8 fehérje van, mint amennyi YFP-UVR8 fehérjét a ProUVR8 növények termelnek, ráadásul az erős túltermelő ProCAB3 vonalak válasza sem haladta meg a vad típusú növényekét (13. ábra, 15. ábra). Feltételezve, hogy az anti-UVR8 ellenanyag ugyanúgy érzékeli az endogén UVR8 és az YFP-UVR8 fehérjéket, és a két fehérje biológiai aktivitása egyforma, megállapíthatjuk, hogy a vad típusban található több fotoreceptor nem váltott ki nagyobb mértékủ elhajlást, tehát már a ProUVR8 vonalunkban lévő, kevesebb fotoreceptor is elég a teljes értékü válaszhoz (13. ábra, 15. ábra). Mivel a ProUVR8 vonalunkban a fotoreceptor termelését az UVR8 saját promótere végzi, valószínüleg a szövetek közti eloszlás sem különbözik a vad típustól, tehát ez nem befolyásolja az összehasonlítást.

A ProSUC2 vonal elhajlását vizsgálva árnyaltabb képet kapunk arról, hogy mely szövet(ek) milyen szinten vesz(nek) részt az elhajlás szabályozásában, valamint arról, hogy 
az UVR8 mennyisége befolyásolja-e az elhajlás mértékét. A ProSUC2 növények több össz-YFP-UVR8 fehérjét termelnek a mezofilljükben/kortexükben (és szállítószöveteikben), mint a ProML1 növények az epidermiszükben (9. ábra), elhajlásuk mértéke mégis közel azonos (13. ábra, 15. ábra). Ez az eredmény alátámasztja, hogy az epidermiszben található UVR8-nak valóban kiemelt szerepe van az UV-B irányú elhajlás szabályozásában, mivel az epidermiszben lévő receptorhoz képest a mezofill/kortex szövetekben több YFP-UVR8 kellett ugyanolyan mértékủ válasz kialakulásához. Az pedig, hogy a ProSUC2 kevésbé hajlik el, mint az YFP-UVR8at magasabb szinten termelő ProCAB3 vonal, azt sugallja, hogy az UVR8 mennyisége is befolyásolja az elhajlás mértékét (13. ábra, 15. ábra). Ezeket a megállapításokat megtehetjük annak ellenére is, hogy a ProSUC2 vonal termel YFP-UVR8-at a mezofill/kortex szövetein kívül a szállítószöveteiben is: mivel a szállítószövetekben található fotoreceptor szerepe minimálisnak tủnik, így a ProSUC2 elhajlása valószínüleg szinte kizárólag a mezofill/kortex szöveteiben termelt YFP-UVR8-nak köszönhető. Mindezek miatt a ProSUC2 vonal tekinthető egy ProCAB3-hoz hasonló vonalnak, ami alacsonyabb szinten termeli az YFP-UVR8-at a mezofill/kortex szöveteiben, így a két vonalra vonatkozó eredmények összehasonlíthatóak egymással, főleg az UVR8 mennyiség befolyásoló hatását tekintve.

\subsubsection{Az UVR8-függő flavonoid felhalmozódás szabályozása}

Azt tapasztaltuk, hogy a csíranövények esetében a megfelelö mennyiségü YFP-UVR8 akár az epidermiszben (ProML1, ProUVR8), akár a mezofillben/szubepidermális sejtekben (ProUVR8, ProCAB3, ProSUC2) található, képes kiváltani a flavonoidok felhalmozódását (16. ábra). Mindemellett a flavonoidok felhalmozódását irányító jel szövetek közötti terjedése, vagy a termelődött flavonoidok szállítása is megtörténhet, esetleg mindkét folyamat együttesen eredményezi a tapasztalt flavonoid-eloszlást (Buer és Muday, 2004). Bár mindegyik transzgenikus növény halmozott fel flavonoidokat UV-B hatására, a detektált flavonoid szint elmaradt a vad típusú növényekben megfigyelttől (16. ábra). Annak ellenére, hogy az epidermiszben és a mezofillben/szubepidermális sejtekben lévő YFP-UVR8 külön-külön is képes flavonoid felhalmozódást kiváltani, az eredmények mégis arra utalnak, hogy a teljes értékü válaszhoz szükség van együttesen, a különböző szövetekben megfelelö szinten elinduló jelátviteli folyamatokra. Az endogén promóter irányításával YFP-UVR8-at termelö ProUVR8 vonalban a flavonoid felhalmozódása elmarad a vad típusétól. Mivel a ProUVR8 sokkal kevesebb YFP-UVR8-at termel, mint amennyi UVR8-at a vad típus, így feltételezhetjük, hogy a ProUVR8 vonalban a kevesebb fotoreceptor okozza az alacsonyabb szintű flavonoid termelést.

A ProML1 vonal a ProCAB3 és ProSUC2 vonalakhoz képest kevesebb YFP-UVR8-at termel, mégis ezzel a két vonaléval megegyező szintü választ adott, tehát itt az epidermiszben található UVR8-nak van kiemelt szerepe, hiszen jóval kevesebb YFP-UVR8 elég volt hasonló 
szintü válasz kiváltására az epidermiszben, mint amennyi a másik két vonal mezofilljében/szubepidermális sejtjeiben található (10. ábra A, 16. ábra). Az adatok továbbá arra utalnak, hogy a teljes értékü flavonoid felhalmozódáshoz szükség van az epidermiszben és a mezofillben elinduló folyamatok együttes hatására: ha csak egyik, vagy másik szövetben van YFP-UVR8, mint a ProML1 és a ProCAB3 vonalak esetében, a válasz szintje elmarad a vad típusétól. Hozzá kell tenni azonban, hogy más magyarázat is létezik a jelenségre: előfordulhat, hogy túl az esetlegesen megnyilvánuló szöveti preferencián, fontosabb az össz-UVR8 mennyisége, bárhol is termelödjön. Mindkét feltevésnek némileg ellentmond azonban, hogy a ProUVR8 növények nem halmoztak fel több flavonoidot a ProML1 növényekhez képest, holott ezek epidermiszében nagyon hasonló szinten fejeződik ki az YFP-UVR8, tehát a ProUVR8 növényekben az epidermiszen kívül termelt szubepidermális YFP-UVR8 nem volt képes érdemben fokozni a flavonoid termelést (10. ábra B, 16. ábra). Erre magyarázat lehet, hogy a ProUVR8 olyan alacsony szinten termel YFP-UVR8-at a mezofill/szubepidermális szöveteiben, hogy az már nem elégséges mérhető flavonoid-felhalmozódás kiváltásához ilyen UV-B kezelés hatására. A ProSUC2 vonal válasza szintén a vad típusénál gyengébbnek bizonyult, ami alapján a szállítószövetekben előforduló YFP-UVR8-nak valószínúleg nincs komoly szerepe a flavonoid felhalmozódás elősegítésében sem (16. ábra).

Felnőtt, vad típusú növények szárából készített metszeteket vizsgálva megállapítottuk, hogy a flavonoidok felhalmozódása a csíranövényekhez hasonlóan, leginkább az epidermiszben és az epidermisz alatti rétegekben figyelhető meg (17. ábra). Az epidermiszben YFP-UVR8-at termelő transzgenikus vonalak (ProML1, ProUVR8) metszetei arra utalnak, hogy felnőtt korban kiemelt szerepe van az epidermiszben található UVR8-nak az UV-B elleni védekezésben. Ez nem meglepő, hiszen ez a szövet van leginkább kitéve UV-B sugárzásnak. Ami változik a fejlődés során, hogy csíranövényekhez képest felnőtt növényekben fontosabb szerephez jut a mezofillben/kortexben található UVR8: felnőtt növények közül az YFP-UVR8-at kortexben termelö ProCAB3 vonal halmozta fel a legtöbb flavonoidot, míg csíranövény állapotban ugyanez a vonal a többivel összehasonlítható mennyiségben termelt flavonoidokat (16. ábra, 17. ábra). A ProCAB3 vonal eredménye azt is sugallja, hogy az UVR8 mennyiségének hatása van a flavonoid termelés mértékére, hiszen ez a legmagasabb szinten YFP-UVR8-at termelő vonalunk.

Elsőre furcsának tünhet, hogy a ProUVR8 nem tartozott a legerősebb flavonoid akkumuláló vonalak közé, a vad típusú növényekhez képest kevesebb flavonoidot halmozott fel a szárában. Erre magyarázat lehet, hogy a legerősebb választ adó ProCAB3 vonalhoz és az endogén UVR8 szinthez képest a ProUVR8 növények kevesebb YFP-UVR8-at termelnek (13. ábra), ami a korábban bemutatott eredményeink alapján befolyásolja a flavonoid felhalmozódás mértékét.

A flavonoidok szövetek közti eloszlását vizsgálva is érdekes megállapítást tehetünk: az YFP-UVR8-at epidermiszükben nem termelö ProCAB3 és ProSUC2 növények epidermiszében is jelentős flavonoid felhalmozódást tapasztaltunk. Az endodermiszben és a bélszövetben 
megfigyelhető alacsony szintű flavonoid felhalmozódás valószínűleg nem járul hozzá érdemben az UV-B elleni védekezéshez, de ezek az eredmények is erősítik a csíranövényekkel kapcsolatban felvetett magyarázatok létjogosultságát, tehát valószínüleg történhet flavonoid transzport (vagy jelátvitel) a szövetek között. További érdekesség, hogy az YFP-UVR8-at epidermiszben termelő ML1 vonalak metszeteiben kizárólag epidermális flavonoid felhalmozódást sikerült kimutatnunk. Ha valóban müködik flavonoid transzport a szövetek között, akkor az eredményeket összegezve csak a kortexből juthat flavonoid az epidermiszbe (valamint az endodermiszbe és a bélszövetbe), fordított irányba nem történik transzfer. Ez abból a szempontból logikus szabályozási sajátság, hogy a flavonoidokra leginkább a növény első védelmi vonalában, vagyis az epidermiszben van szükség, ezért elsődlegesen az a fontos, hogy ott megfelelő mennyiségü flavonoid álljon rendelkezésre UV-B sugárzás esetén. Kevésbé valószínű, bár továbbra is lehetséges magyarázat az UVR8 által kiváltott jel szövetek közti terjedése, de ebben az esetben ennek a flavonoid termelésre specifikusnak kellene lennie, mivel tapasztalataink alapján más folyamatok során nem jellemző az UVR8 jel terjedése a szövetek között.

A növények védekező válasza függ az UV-B sugárzás irányától és az ebből következő UVR8 aktivitástól, ugyanis felnőtt növények szárában egyértelmúen több flavonoid halmozódik fel a megvilágított oldalon, mint az árnyékos félen (17. ábra). A flavonoid akkumuláció mintázatából következtethetünk arra, hogy nem jellemző az UVR8 jel átterjedése a szár megvilágított oldaláról az árnyékos oldalra. Túl azon, hogy valószínüleg a jel nem terjed át az árnyékos szárrészre, eredményeink alapján a flavonoidok transzportja sem történik meg a szár árnyékolt oldalára. Ha az UVR8 jel mégis átterjedne az árnyékos szárrészbe, a flavonoidok egyenetlen felhalmozódását csak egy UVR8-tól független, de fényfüggő szabályozó mechanizmus által elindított, meghatározott irányú flavonoid transzport okozhatná. Kísérleteink alapján valószínűbb, hogy a szár megvilágított és árnyékos oldala között nem történik meg az UVR8 által elindított jelátviteli folyamatok terjedése, így a flavonoidok szállításának sincs létjogosultsága. A flavonoid-gradiens kialakulása alátámasztja a korábban bemutatott irodalmi adatok alapján kialakult feltevést, miszerint az UVR8 egyenetlen eloszlása az UV-B-től függő fototropikus válaszok kialakulásához is nagyban hozzájárul, főleg az auxin növekedési hormon müködésének helyspecifikus gátlása által, amit a HY5 (és HYH) megvilágított oldali, UVR8 által fokozott aktivitása nagyban elősegít (Vandenbussche és Van Der Straeten, 2014) (3. ábra). 


\subsection{UVR8 jelátvitel: génindukció}

\subsubsection{A kalkon szintáz (CHS) génjének aktivitása UV-B sugárzás alatt}

Annak érdekében, hogy az UV-B által elindított jelátviteli láncok müködésébe betekintést nyerjünk, megvizsgáltuk néhány UVR8 által szabályozott gén müködését. A flavonoid szintézis egyik kulcs enzime a kalkon szintáz, aminek a génje UVR8-függő módon indukálódik: vad típusúval ellentétben $u v r 8$ mutáns növényekben nem tapasztaltuk a gén transzkripciójának emelkedését UV-B sugárzás hatására (18. ábra). Mivel a flavonoidok a szárban a megvilágított oldalon sokkal nagyobb mennyiségben halmozódnak fel, mint az árnyékoson, megvizsgáltuk a kalkon szintáz indukciójának térbeli eloszlását is. A tapasztalt egyenetlen flavonoid felhalmozódást a gén egyenetlen indukálódása okozza, vagy legalábbis nagyban elősegíti: vad típusú növényben a hosszában elvágott szárrész megvilágított oldalán erősebb CHS müködést tapasztaltunk az árnyékos oldalihoz képest (18. ábra). Ez az eredmény szintén alátámasztja, hogy az UVR8 aktivitása oda korlátozódik, ahol nagyobb mennyiségben fordul elő aktív állapotban. Az eredmények alapján nem történik flavonoid transzport a megvilágított részekbe a szár árnyékos feléből, hiszen ott a CHS gén müködése elhanyagolható, vagyis abban a szárrészben számottevően nem termelődnek flavonoidok. Ez a jelenség kifejezetten hasznos a növényeknek abból a szempontból, hogy csak azokban a növényi részekben kell energiát használniuk a flavonoidok felhalmozására, ahol azokra valóban szükség van az erősebb UV-B sugárzás miatt.

\subsubsection{A HY5 és HYH UVR8-függő indukciója}

Az UVR8 jelátvitelében kulcsfontosságú HY5 transzkripciós faktor felhalmozódása függ az UVR8 fotoreceptortól: $u v r 8$ mutánsban sem a csíra-, sem a felnőtt növényben nem tapasztaltunk HY5-YFP felhalmozódást (19. ábra, 21. ábra) vagy HY5 transzkripció-indukciót (20. ábra, 22. ábra A). Transzgenikus vonalainkban a HY5-GFP termelődése is csak azokra a szövetekre korlátozódott, amelyek tartalmaztak kimutatható mennyiségü YFP-UVR8 receptort (19. ábra). Ez a megfigyelésünk azt mutatja, hogy az UVR8 a phyA-hoz hasonlóan aktiválja a HY5-ot (Kirchenbauer és mtsai., 2016), tehát mindkét fotoreceptor szövetautonóm módon indítja el a fotomorfogenikus válaszokhoz vezető korai jelátviteli lépéseket, például a $H Y 5$ gén indukcióját.

A hy5uvr8, illetve a hy5 mutáns hátterü, HY5:HY5-YFP transzgént kifejező felnőtt növényeket egy irányból, oldalról UV-B sugárzással kezeltük. HY5-YFP felhalmozódását a szárban csak UVR8 jelenlétében figyeltünk meg, míg UVR8 hiányában egyáltalán nem. Ez a jelenség a szárnak arra az oldalára korlátozódott, ahol az UV-B sugarak érték a növényt 
(21. ábra A, B). Mivel a HY5 csökkenti az auxinválasz mértékét a jelátvitelhez köthető gének szabályozása révén (Vanhaelewyn 2016), kizárólagos jelenléte a megvilágított oldalon előidézi a szár elhajlását UV-B sugárzás irányába. A csíranövényekkel végzett hasonló megfigyelések alapján (Vandenbussche és Van Der Straeten, 2014) (3. ábra) mindebből azt feltételezhetjük, hogy az UVR8-nak nem csak az HY5-szintet emelő hatása helyspecifikus, de a HY5 auxinválaszokra gyakorolt hatása is a HY5 jelenlétéhez kötött és nem terjed el máshova a felhalmozódás helyétől (21. ábra A, B). Ez a HY5-függő folyamat lehet az egyik oka az UV-B hatására kiváltott, fénytől függő differenciált növekedési válaszoknak, amiknek a következménye jelen esetben az UV-B irányába megfigyelhető szárelhajlás.

A fentebb bemutatott kísérletet elvégeztük hyh és hy5hyh háttérben $H Y H: H Y H-Y F P$ transzgént termelő vonalakkal is (21. ábra C). A HYH a HY5-hoz hasonlóan szintén az UV-B kezelt oldalon halmozódik fel felnőtt növények szárában (21. ábra). A hy5hyh dupla mutáns vonallal végzett kísérletek eredményei mindezeken felül arra engednek következtetni, hogy a HY5 jelenléte elősegíti a HYH fehérje termelődését: számottevően több HYH-YFP-t tudtunk detektálni a hyh hátterü növények szárában, mint a hy5hyh növényekében (21. ábra C). Erre kézenfekvő magyarázat lehet a két fehérje nagyon hasonló müködése: mivel a HY5 saját felhalmozódására pozitívan hat (Binkert és mtsai., 2014), a nagyfokú hasonlóság miatt nem meglepö, hogy a HYH termelést is képes fokozni.

Megvizsgáltuk, hogy a HY5 illetve a HYH gradiens felnőtt növények szárában már transzkripciós szinten is érvényesül-e, vagy kizárólag fehérjeszintủ szabályozás, például árnyékos oldali fehérjedegradáció okozza-e a kialakult egyenetlen felhalmozódást. A szár megvilágított oldalán jelentősen nagyobb HY5 és HYH mRNS mennyiséget mértünk (22. ábra), ami arra utal, hogy az UVR8 a HY5 és a HYH gradiens kialakulását már transzkripciós szinten elősegíti azzal, hogy csak az UV-B sugárzás helyén aktiválja a $H Y 5$ és $H Y H$ géneket, tehát az UVR8-függő, HY5 (és $H Y H$ ) gént aktiváló jel sem terjed el az UV-B besugárzás helyétől. A HY5 és HYH fehérjék szárban megfigyelhető egyenetlen eloszlása nagyban hozzájárul a csíranövényekéhez hasonló, egyoldali UV-B megvilágítás következtében megfigyelhető szárelhajláshoz.

\subsubsection{Az ELIP2 és a PRR9 gén indukciója UV-B hatására}

Nem meglepő, hogy az ELIP2 indukciója a HY5 génhez hasonlóan (valójában a HY5 felszaporodásától függően) történik, mivel az ELIP2 expressziója HY5-függő: csak ott indukálódhat, ahol jelen van kellő mennyiségü HY5 fehérje (23. ábra, 24. ábra). Érdekes módon, annak ellenére, hogy a HY5 képes vándorolni a növények szervein és szövetein keresztül (Chen és mtsai., 2016), az általunk vizsgált válaszban az UV-B kezelést követően csak azokban a szövetben találtunk HY5-ot, amelyikben kimutatható mennyiségü UVR8 is jelen volt (19. ábra). Ezzel együtt 
az ELIP2 indukciója az YFP-UVR8-at tartalmazó szövetekre korlátozódott, tehát ebben az esetben a HY5 nem közvetítette az UVR8 hatását más szövetekbe.

Érdekes a $P R R 9$ HY5-töl függetlenül megemelkedő expressziója, ami csak azokban a szövetekben figyelhető meg UV-B hatására, amelyekben volt detektálható mennyiségü YFP-UVR8 (kivéve az epidermiszben, de ez a $P R R 9$ sajátos szabályozásának a következménye) (25. ábra, 26. ábra). Ez arra utal, hogy az UVR8 jelátvitelében megfigyelhető (akár szövetautonóm) válaszok nem kizárólag az aktív UVR8 miatt szövetspecifikusan termelődő HY5 további hatásaiból eredeztethetőek, léteznek más, HY5-tól független szövetautonóm útvonalak is, melyek bizonyos gének indukálásához vezetnek. Ezeknek a jelátviteli útvonalaknak a felderítése számos további kutatási lehetőséget kínál. 


\section{7.ÖSSZEFOGLALÁS}

A növények ki vannak téve a környezetben tapasztalható folyamatos változásoknak, ezért ezekhez alkalmazkodniuk kell. Az egyik legfontosabb környezeti tényezö a fény, mivel a növények energiaforrásként hasznosítják, azonban a napfény, éppen magas energiatartalma miatt, akár komoly károkat is okozhat. Annak érdekében, hogy a növények a fényviszonyokhoz alkalmazkodni tudjanak, különböző hullámhosszúságú fényben müködö fotoreceptorokat használnak a fény mennyiségi, minőségi, időbeli, illetve irányában bekövetkező változásainak követésére.

A természetes napfény része az UV-B sugárzás, aminek érzékelése kiemelten fontos, ugyanis a napfényben az UV-B sugarak rendelkeznek a legnagyobb energiatartalommal, ami miatt könnyen károsíthatják a növények makromolekuláit. A növények a védekezésük érdekében jelként is képesek az UV-B sugarakat érzékelni, amiben az UVR8 fotoreceptornak van a legfontosabb szerepe. Az UV-B által aktivált UVR8 a COP1 E3 ubiquitin ligáz inaktiválása révén a HY5 transzkripciós faktort felszabadítja a COP1 általi gátlás alól, ennek következtében fotomorfogenikus válaszok indulnak el a növényben. Az UVR8 aktiválódás hatására számos egyéb folyamat is elindul, ilyen például az UV-B szürö flavonoidok felhalmozódása. Az UVR8 szerteágazó hatása annak köszönhetö, hogy jelátviteli rendszere szorosan összefonódik más fotoreceptorokéval és sokféle hormonális jelátvitel müködésével is kapcsolatban áll.

A fényhez kötött jelátviteli rendszerekben sok példát találhatunk szerv-, illetve szövetspecifikus részfolyamatokra, amelyek összehangolt müködésük révén, akár szöveti autonómiát nem mutató egyéb részfolyamatokkal együtt, kialakítják a szükséges összetett válaszreakciót. Éppen ezért, ha átfogó képet szeretnénk kapni egy adott válaszreakció lefolyásáról, érdemes a részfolyamatok jellegzetességeire koncentrálni. Mivel az UVR8-cal kapcsolatban eddig nem vizsgálták a jelátviteli folyamatok szövetspecificitását, célul tüztük ki, hogy YFP-UVR8 fehérjét bizonyos szövetekben termelő transzgenikus Arabidopsis növények segítségével megvizsgáljuk a legismertebb UVR8-függő válaszok szövettípusoktól függő, vagy független lefolyását. Kísérleti eredményeink alapján a következő következtetéseket tehetjük:

- Az UVR8 saját promóterével kifejeztetett YFP-UVR8 fehérje a csíranövények epidermisz és a mezofill sejtjeiben biztosan termelődik.

- A mutáns komplementációs tesztek alapján megállapítható, hogy a csíranövényekben a hipokotil megnyúlás gátlásában az epidermális és a mezofillben található UVR8 együttmüködve vesz részt, míg a sziklevél növekedését kizárólag az epidermiszben található UVR8 fotoreceptor képes elősegíteni. Eredményeink alapján a hipokotil hosszára és a sziklevelek méretére a szállítószövetben termeltetett YFP-UVR8 (nagy valószínüséggel) nincs hatással. 
- A fehér fénnyel együtt alkalmazott kiegészítő UV-B sugárzás hatására bekövetkező fotomorfogenikus és UV-B akklimációs válaszokat leginkább a felnőtt növények kortexében/mezofilljében lévő UVR8 képes elindítani, de a teljes válaszok kialakulásához szükséges az epidermiszben található UVR8 is. A klorofilltartalom emelkedését szintén leginkább a kortex/mezofill sejtekben található UVR8 indítja el, az UVR8 mennyiségével arányos mértékben.

- Csíranövényekben és felnőtt növényekben egyaránt megfigyelhető az UVR8-függő flavonoid felhalmozódás. Legnagyobb mennyiségben azokban a szövetekben termelődnek flavonoidok, ahol az UVR8 megtalálható, a teljes értékü válasz kialakulásához viszont szükség van a különböző szövetekben lejátszódó autonóm jelátviteli mechanizmusok összességére.

- Az egy irányból megvilágított felnőtt növények szárában megfigyelhető az UVR8-függő flavonoid felhalmozódás az UV-B-vel besugárzott oldalon. Ez arra utal, hogy az UVR8 ebben az esetben helyspecifikusan, a megvilágított szövetekben fejti ki hatását, nincs jelterjedés az árnyékos oldalra.

- Felnőtt növények esetében több esetben találtunk YFP-UVR8-at nem tartalmazó szövetekben is flavonoidokat, ami a flavonoidok mozgására, transzportjára utal.

- Felnőtt korban is fontos az epidermiszben található UVR8 a flavonoidok felhalmozásához, viszont a kortexben található UVR8-nak sokkal fontosabbá válik a szerepe, mint csíranövény állapotban. Az UVR8 fehérje mennyiségének is komoly hatása van a flavonoid felhalmozódás mértékére.

- Kimutattuk azt is, hogy a flavonoid termelés egyik kulcsenzimét kódoló CHS gén UV-B indukciója csak azokban a sejtekben következik be, melyekben van aktív YFP-UVR8. Ez a helyspecifikus génindukció lehet a flavonoid felhalmozódás kiváltója.

- Felnőtt növényeken megfigyeltük az unilaterális UV-B sugárzás irányába bekövetkező szárelhajlást. Ez hasonlít a csíranövények hipokotiljának korábban leírt reakciójára, azonban míg a felnőtt növényekben a folyamatot dominánsan irányító fotoreceptor az UVR8, valamint a fototropinok elhanyagolható szerepet játszanak benne, addig a csíranövények válaszában a fototropinok szerepe hangsúlyosabb. Ez arra utal, hogy a virágzati tengely fototropikus válaszait irányító jelátviteli mechanizmusok inicializálása eltér a hipokotilétól. A szár elhajlását UV-B sugárzás felé az epidermiszben és a mezofillben/kortexben termelődő UVR8 is kiváltja és az elhajlás mértékét befolyásolja az UVR8 mennyisége.

- Az UVR8 irányította jelátvitelben kulcsszerepet játszó HY5 fehérje felhalmozódása, valamint a HY5 gén indukciója szövetautonóm: a csíranövényeknek csak azokban a szöveteiben következett be a génindukció és a HY5 szint emelkedése, amelyekben volt 
kimutatható mennyiségü UVR8. Ez azt bizonyítja, hogy ezekben a folyamatokban nincs szövetek közötti jelterjedés.

- Felnőtt növények szárában a HY5 és a vele homológ HYH felhalmozódása is UVR8-függő módon, csak az UV-B-vel megvilágított oldalon figyelhető meg. Mivel a HY5 az auxin növekedési hormon hatását helyspecifikusan gátolja, ez a jelenség hozzájárulhat a megvilágított és az árnyékos oldal között megfigyelhető egyenetlen auxinválaszhoz, aminek egyenetlen szárnövekedés, vagyis UV-B irányba megfigyelhető elhajlás a következménye.

- A HY5-függő ELIP2 és a HY5-független $P R R 9$ génexpresszió UV-B általi megemelkedését az UVR8 váltotta ki, de csak azokban a szövetekben, amelyekben volt kimutatható mennyiségü YFP-UVR8. (Ez alól kivétel a PRR9 epidermális indukciója, ugyanis ez a gén ebben a szövetben nem indukálódik, de ez a ProPRR9 sajátos müködése miatt történik.) Ezek alapján az UVR8 által indított jelátviteli lépések szövetspecifitása nem csak abból eredhet, hogy a jelátvitelben kiemelt szereppel bíró HY5 felhalmozódása szöveti autonómiát mutat, mivel a HY5-tól független PRR9 szintén szövetspecifikusan indukálódik.

Összesítve az eredményeket megállapíthatjuk, hogy az UVR8 jelátviteli rendszerében szövetautonóm és szöveti specificitást nem mutató folyamatok egyaránt elöfordulnak, ezek sokszor együttesen fejtik ki hatásukat a megfelelő összetett válaszok kialakulása érdekében. Az UVR8 jelátviteli rendszerének egyre részletesebb ismerete újabb és újabb lehetőségeket biztosít a további részfolyamatok autonómiájának felderítésére, így a jövőben számos alkalom fog nyílni kísérletek tervezésére az általunk is alkalmazott megközelítéssel. Ha ezeket a folyamatokat felderítjük, a jelátvitelhez tartozó komplex válaszreakciók manipulálhatósága egy magasabb szintre kerülhet, ugyanis UVR8 (esetleg más jelátvitelben szereplő receptorok), vagy egyéb faktorok adott szövet(ek)ben történő termelődésének befolyásolása által erősíthetőek, vagy gyengíthetőek lennének egyes részfolyamatok külön-külön is. Az UV-B jelátvitel alaposabb megismerése olyan tudással ruház fel bennünket, amivel elősegíthetjük a növények túlélését, akklimációját erősebb UV-B sugárzásban, vagy akár megfelelő, UV-B sugárzással kiegészített fénykezeléseknek köszönhetően erősíthetjük a növények kártevők elleni védekezését is. Ezeket az ismereteket természetesen a haszonnövények hatékonyabb termelésével kapcsolatban is tudnánk kamatoztatni. 


\section{SUMMARY}

\subsection{Introduction}

Plants are exposed to the ever-changing environmental cues. Light is one of the most important environmental factor for plants: it is essential not only for producing energy by photosynthesis, but also as a signal, which helps plants to optimize their growth and development in the changing environment. On the other hand, sunlight can cause serious damages due to its high energy content. There are several processes which are influenced by light, for example germination, development of seedlings, phototropism, shade avoidance, chloroplast movements, opening of stomas and most of the rhythmic processes during the whole lifecycle of plants (Sullivan and Deng, 2003). Thus, plants have evolved various photoreceptors in order to monitor the duration, the wavelength, the intensity, the direction and the rhythmicity of the surrounding light. In the widely used modal plant, Arabidopsis thaliana, these receptors are the blue/UV-A light absorbing phototropins, cryptochromes and Zeitlupe-type receptors (Briggs, 2007), the red/far-red absorbing phytochromes (phyA-phyE) (Schäfer and Bowler, 2002; Bae and Choi, 2008) and the UV RESISTANCE LOCUS 8 (UVR8) UV-B photoreceptor (Rizzini et al., 2011).

UV-B radiation (280-315 nm) is a part of sunlight which reaches the Earth's surface. This part of the sunlight has the largest energy content, so UV-B can easily damage macromolecules (DNA, proteins, lipids, etc.), causing stress, or even irreversible damages (Hollósy, 2002). For this reason, it is crucial for the plants to perceive UV-B and start signalling cascades in order to adapt to UV-B irradiation and even initiate repair mechanisms to reduce the damage caused by UV-B.

It has long been assumed that UV-B radiation can result in photomorphogenic changes irrespective of considerable DNA damage. However, it took many years to identify a UV-Bspecific receptor in Arabidopsis, the UVR8 (Rizzini et al., 2011). UVR8 is a seven-bladed $\beta$-propeller protein that normally forms homodimers, which monomerize upon UV-B irradiance, leading to the enrichment of physiologically active UVR8 monomers (Christie et al., 2012). Nuclear UVR8 accumulation is a necessary, however not sufficient step of UVR8 signalling cascades (Kaiserli and Jenkins, 2007). An early step of the UVR8 signalling cascade after the receptor monomerization is the interaction between UVR8 and an E3 ubiquitin ligase, named CONSTITUTIVE PHOTOMORPHOGENIC 1 (COP1), which is needed for the nuclear import of UVR8 (Yin et al., 2016). Later, due to the interaction, COP1 is not able to ubiquitinate its target proteins (Favory et al., 2009; Rizzini et al., 2011; Huang et al., 2013). When UVR8 is active, it 
inhibits ELONGATED HYPOCOTYL 5 (HY5) and HY5 HOMOLOG (HYH) ubiquitination by COP1, which are positive regulators of photomorphogenesis. Additionally UVR8 induces the expression of the HY5 and HYH genes (Osterlund et al., 2000; Lau and Deng, 2012). Thus, UVR8 promotes photomorphogenesis by inducing high levels of HY5 and HYH proteins, leading to different responses such as inhibition of hypocotyl elongation in one hand, and enhanced synthesis of photoprotective pigment molecules for example by upregulating, for example, the CHALCONE SYNTHASE (CHS) flavonoid biosynthesis gene (Jenkins et al., 2001), leadint to better survival under UV-B radiations (Oravecz et al., 2006). UVR8 signalling is tightly linked to several pathways, regulated by other photoreceptors and hormones (Vanhaelewyn et al., 2016). The intimate relationship between UVR8 and auxin signalling has been examined extensively. The most important molecular link which connects these pathways is the HY5, since HY5 can inhibit auxin responses under UV-B irradiation. (Vandenbussche and Van Der Straeten, 2014).

It is known, that there are signals which do not spread between different tissues in the plant, these are termed tissue-autonomous or tissue-specific. Such processes were discovered and examined in the signalling pathways of different photoreceptors. The hypocotyl bending response of phyA can be triggered exclusively by phyA in the mesophyll but not in the epidermis or vasculature (Kirchenbauer et al., 2016). It was also found that some responses are controlled by inter-tissue signal spreading, like regulation of certain genes involved in cell growth (Kirchenbauer et al., 2016). Despite the gained data from different photoreceptors, the tissue autonomous or intertissue aspects of UVR8 signalling has not yet been studied. To achieve this, we developed a transgenic plant-based experimental system using promoters which are active in certain tissues and we monitored the chosen proteins of interest at tissue level using confocal laser scanning microscopy. We supplemented these observations with diverse phenotyping studies obtained from different development stages of the universal dicot model plant, Arabidopsis thaliana.

\subsection{Conclusions}

There are tissue-autonomous mechanisms working together with non-autonomous regulation processes in the light signalling system. UVR8 is taking part in this by triggering tissueautonomous and non-autonomous sub-processes as well, which are needed together for proper UV-B responses just like photomorphogenic growth inhibition, phototropic stem bending, or flavonoid accumulation. To expand our knowledge about the UVR8 signaling we developed transgenic plants expressing the YFP-UVR8 protein in particular tissues of the $u v r 8$ mutant and investigated their UVR8-related UV-B responses. Taken together, our results revealed, that: 
- YFP-UVR8 was detectable in the epidermis and in the mesophyll/cortex, where the fusion protein was expressed under the control of its own endogenous promoter. However, we cannot exclude that UVR8 is present in the vasculature.

- The mutant complementation tests revealed that YFP-UVR8 could trigger photomorphogenic hypocotyl elongation inhibition if it is present in the epidermis and in the mesophyll/subepidermal cells.

- YFP-UVR8 could restore cotyledon expansion phenotype of the $u v r 8$ mutant background, when it was expressed in the epidermis. The UVR8 in the mesophyll/subepidermal cells does not have a role in this response, thus this process is strictly tissue-autonomous.

- YFP-UVR8 expressed in the vascular bundles has a very limited, if any role in regulating hypocotyl elongation and cotyledon expansion.

- The weak supplemental UV-B treatment we applied was suitable for investigating the photomorphogenic UV-B responses of adult plants. The stronger supplemental UV-B treatment however triggered the responses needed for acclimation and survival. Our results suggest that in the regulation of chlorophyll accumulation, photomorphogenic and acclimation responses, UVR8 plays a major role in the mesophyll/cortex, rather than in the epidermis. It seems that these responses are influenced by the overall UVR8 level of the plants.

- UVR8-dependent flavonoid accumulation can be detected in all of our transgenic seedlings, however the flavonoid levels were lower compared with the wild type. It seems that UVR8 plays a major role in the epidermis, since less epidermal than cortical/subepidermal UVR8 is enough for inducing comparable flavonoid accumulation during seedling stage.

- In case of adult plants, epidermal UVR8 plays a major role in triggering flavonoid accumulation, however cortical UVR8 become more important compared to seedling stage. We could detect flavonoids not only in those tissues, which expressed YFP-UVR8: in ProCAB3 and ProSUC2 plants we could detect high amount of flavonoids in the epidermis, despite the fact that these plants do not express YFP-UVR8 in this tissue. In the ProML1 line which expresses YFP-UVR8 exclusively in the epidermis we could detect flavonoids only in the epidermis. Taken together, flavonoid transport can happen between neighbouring tissues, but it is directed only from cortex to epidermis, not vice versa. 
- Under unilateral UV-B irradiation, the UVR8-dependent induction of CHS (CHALCONE SYNTHASE, coding for a key enzyme in flavonoid biosynthesis) was much stronger in the UV-B irradiated side of the stem, compared to its shaded side. We found that flavonoids accumulate in a very similar manner, and the overall flavonoid level was influenced by the YFP-UVR8 level. UVR8 can lead to CHS upregulation, only in those parts of the plant where it is irradiated.

- Unilateral UV-B treatment triggers bending of the stem towards UV-B irradiation. This response depends mainly on UVR8 and has negligible phototropin influence compared to young seedlings. Both in the epidermis and in the mesophyll/cortex, UVR8 can trigger stem bending towards UV-B, and it seems that UVR8 signalling is more effective in the epidermis.

- The UVR8-dependent HY5 gene induction and HY5 accumulation are tissue-autonomous, since these responses only happen in those particular tissues, where detectable YFP-UVR8 is present in our lines. This finding shows that there is no signal spreading between tissues regarding these regulatory processes.

- Both HY5 and HYH gene induction as well as HY5 and HYH protein accumulation takes place in the UV-B irradiated side of the stem, which contributes to site-specific inhibition of auxin triggered growth responses. This phenomenon enhances the stem bending towards UV-B, because of the unequal growing between the irradiated and the shaded side of the stem. This finding also proves, that there is no UVR8 signal spreading from the irradiated side towards the shaded side of the stem (just like in the case of $C H S$ gene activation, and flavonoid accumulation). Additionally HY5 can enhance $H Y H$ induction during UV-B irradiation.

- The HY5-dependent ELIP2 gene induction, and the HY5-independent PRR9 gene induction are also regulated by UV-B in a UVR8-dependent manner. Both of these responses are strictly tissue-autonomous.

Taken together, there are tissue-autonomous and non-tissue-autonomous processes working together in UVR8 signalling system in order to trigger proper UVR8 responses. Despite the increasing knowledge of UVR8 signalling cascades, there are still many unknown parts of it, so in the future there will be many possibilities to plan new experiments. Revealing more and more about the UVR8 signalling system will give us the chance to manipulate particular UV-B related sub-processes in order to enhance development and survival, defence against herbivores. Moreover, favourable illumination of crop plants with supplemental weak UV-B, combined with gene manipulation could increase crop yield of plants in horticultures. 


\section{SAJÁT KÖZLEMÉNYEK}

\section{Tudományos cikkek}

\section{A dolgozat alapjául szolgáló közlemény:}

Bernula P., Crocco C. D., Arongaus A. B., Ulm R., Nagy F., Viczián A. (2017).

Expression of the UVR8 photoreceptor in different tissues reveals tissue autonomous features of UV-B signalling. Plant Cell Environ. Jul;40(7), 1104-1114.

doi: 10.1111/pce.12904. Epub 2017 Mar 27. PMID: $28058744 \mathrm{IF}_{2017}: 5,415$

Hajdu A., Ádám É., Sheerin D. J., Dobos O., Bernula P., Hiltbrunner A., Kozma-Bognár L., Nagy F. (2015). High-level expression and phosphorylation of phytochrome $B$ modulates flowering time in Arabidopsis. Plant J. Sep;83(5), 794-805.

doi: 10.1111/tpj.12926. Epub 2015 Jul 18. PMID: 26120968 IF $_{2015}: 5.468$

\section{Poszterek}

Wodala, B., Ördög, A., Ayaydin, F., Bernula, P., Horváth, F.

Investigating pathogen elicitor-induced stomatal responses in various plant species $11^{\text {th }}$ Croatian Biological Congress Šibenik, 2012

Vanhaelewyn, L., Serrano, A., Viczián A., Bernula, P., Prinsen, E., Arana, V., Ballaré, C., Van Der Straeten, D., Vandenbussche, F.

Progressive alterations in ultraviolet-B induced phototropism during Arabidopsis development

Plant Biology meeting of American Society of Plant Biologists (ASPB), Honolulu, 2017

Vanhaelewyn, L., Bernula, P., Van Der Straeten, D., Viczián A., Vandenbussche, F. Ultraviolet-B induced phototropism in Arabidopsis inflorescence stems

Plant Biology meeting of American Society of Plant Biologists (ASPB), Montreal, 2018

MTMT azonosító: 10050867 


\section{IDÉZETT KÖZLEMÉNYEK}

1. A.-H.-Mackerness, S., Surplus, S. L., Blake, P., John, C. F., Buchanan-Wollaston, V., Jordan, B. R. és mtsai. (1999). Ultraviolet-B-induced stress and changes in gene expression in Arabidopsis thaliana: role of signalling pathways controlled by jasmonic acid, ethylene and reactive oxygen species. Plant, Cell és Environment, 22(11), 1413-1423.

2. Abas, L., Benjamins, R., Malenica, N., Paciorek, T., Wisniewska, J., Moulinier-Anzola, J. C. és mtsai. (2006). Intracellular trafficking and proteolysis of the Arabidopsis auxin-efflux facilitator PIN2 are involved in root gravitropism. Nat Cell Biol, 8(3), 249-256.

3. Adam, E., Kozma-Bognar, L., Dallmann, G., és Nagy, F. (1995). Transcription of tobacco phytochrome-A genes initiates at multiple start sites and requires multiple cis-acting regulatory elements. Plant Mol Biol, 29(5), 983-993.

4. Agati, G., Biricolti, S., Guidi, L., Ferrini, F., Fini, A., és Tattini, M. (2011). The biosynthesis of flavonoids is enhanced similarly by UV radiation and root zone salinity in L. vulgare leaves. J Plant Physiol, 168(3), 204-212.

5. Ahmad, M., Grancher, N., Heil, M., Black, R. C., Giovani, B., Galland, P. és mtsai. (2002). Action spectrum for cryptochrome-dependent hypocotyl growth inhibition in Arabidopsis. Plant Physiol, 129(2), 774-785.

6. Ahmad, M., Jarillo, J. A., és Cashmore, A. R. (1998). Chimeric proteins between cry1 and cry2 Arabidopsis blue light photoreceptors indicate overlapping functions and varying protein stability. Plant Cell, 10(2), 197-207.

7. Ahmad, M., Jarillo, J. A., Smirnova, O., és Cashmore, A. R. (1998). Cryptochrome bluelight photoreceptors of Arabidopsis implicated in phototropism. Nature, 392(6677), 720723.

8. Aphalo, P. J., Albert, A., Björn, L. O., McLeod, A., Robson, T. M., Rosenqvist, E. és mtsai. (2012). Beyond the visible: A handbook of best practice in plant UV photobiology. COST Action FA0906 UV4growth. Helsinki: Universiti of Helsinki, Division of Plant Biology., ISBN: 978-952-10-8362-4.

9. Azuma, Y., Renault, L., Garcia-Ranea, J. A., Valencia, A., Nishimoto, T., és Wittinghofer, A. (1999). Model of the ran-RCC1 interaction using biochemical and docking experiments. J Mol Biol, 289(4), 1119-1130.

10. Bae, G., és Choi, G. (2008). Decoding of light signals by plant phytochromes and their interacting proteins. Annu Rev Plant Biol, 59, 281-311.

11. Bai, Y., Falk, S., Schnittger, A., Jakoby, M. J., és Hulskamp, M. (2010). Tissue layer specific regulation of leaf length and width in Arabidopsis as revealed by the cell autonomous action of ANGUSTIFOLIA. Plant J, 61(2), 191-199.

12. Ballare, C. L., Mazza, C. A., Austin, A. T., és Pierik, R. (2012). Canopy light and plant health. Plant Physiol, 160(1), 145-155.

13. Baskin, T. I., és Iino, M. (1987). AN ACTION SPECTRUM IN THE BLUE and ULTRAVIOLET FOR PHOTOTROPISM IN ALFALFA*. Photochemistry and Photobiology, 46(1), 127-136.

14. Bauer, D., Viczián, A., Kircher, S., Nobis, T., Nitschke, R., Kunkel, T. és mtsai. (2004). Constitutive Photomorphogenesis 1 and Multiple Photoreceptors Control Degradation of Phytochrome Interacting Factor 3, a Transcription Factor Required for Light Signaling in Arabidopsis. The Plant Cell, 16(6), 1433-1445.

15. Binkert, M., Crocco, C. D., Ekundayo, B., Lau, K., Raffelberg, S., Tilbrook, K. és mtsai. (2016). Revisiting chromatin binding of the Arabidopsis UV-B photoreceptor UVR8. BMC Plant Biol, 16(42), 016-0732.

16. Binkert, M., Kozma-Bognar, L., Terecskei, K., De Veylder, L., Nagy, F., és Ulm, R. (2014). UV-B-responsive association of the Arabidopsis bZIP transcription factor ELONGATED HYPOCOTYL5 with target genes, including its own promoter. Plant Cell, 26(10), 4200-4213. 
17. Bornman, J. F., Reuber, S., Cen, Y. P., és Weissenböck, G. (1997). Ultraviolet radiation as a stress factor and the role of protective pigments. In P. Lumsden (Ed.), Plants and UV-B: Responses to Environmental Change (pp. 157-168). Cambridge: Cambridge University Press.

18. Bouly, J. P., Giovani, B., Djamei, A., Mueller, M., Zeugner, A., Dudkin, E. A. és mtsai. (2003). Novel ATP-binding and autophosphorylation activity associated with Arabidopsis and human cryptochrome-1. Eur J Biochem, 270(14), 2921-2928.

19. Breuninger, H., és Lenhard, M. (2010). Control of tissue and organ growth in plants. Curr Top Dev Biol, 91, 185-220.

20. Briggs, W. R. (2007). The LOV domain: a chromophore module servicing multiple photoreceptors. J Biomed Sci, 14(4), 499-504.

21. Briggs, W. R., és Christie, J. M. (2002). Phototropins 1 and 2: versatile plant blue-light receptors. Trends Plant Sci, 7(5), 204-210.

22. Brown, B. A., Cloix, C., Jiang, G. H., Kaiserli, E., Herzyk, P., Kliebenstein, D. J. és mtsai. (2005). A UV-B-specific signaling component orchestrates plant UV protection. Proc Natl Acad Sci U S A, 102(50), 18225-18230.

23. Brown, B. A., Headland, L. R., és Jenkins, G. I. (2009). UV-B action spectrum for UVR8mediated HY5 transcript accumulation in Arabidopsis. Photochem Photobiol, 85(5), 11471155 .

24. Brown, B. A., és Jenkins, G. I. (2008). UV-B signaling pathways with different fluencerate response profiles are distinguished in mature Arabidopsis leaf tissue by requirement for UVR8, HY5, and HYH. Plant Physiol, 146(2), 576-588.

25. Brown, D. E., Rashotte, A. M., Murphy, A. S., Normanly, J., Tague, B. W., Peer, W. A. és mtsai. (2001). Flavonoids act as negative regulators of auxin transport in vivo in arabidopsis. Plant Physiol, 126(2), 524-535.

26. Buer, C. S., és Muday, G. K. (2004). The transparent testa4 Mutation Prevents Flavonoid Synthesis and Alters Auxin Transport and the Response of Arabidopsis Roots to Gravity and Light. The Plant Cell, 16(5), 1191-1205.

27. Casal, J. J. (2013). Photoreceptor signaling networks in plant responses to shade. Annu Rev Plant Biol, 64, 403-427.

28. Casal, J. J., Candia, A. N., és Sellaro, R. (2014). Light perception and signalling by phytochrome A. J Exp Bot, 65(11), 2835-2845.

29. Casati, P., és Walbot, V. (2004). Rapid transcriptome responses of maize (Zea mays) to UV-B in irradiated and shielded tissues. Genome Biol, 5(3), 2004-2005.

30. Cerdan, P. D., és Chory, J. (2003). Regulation of flowering time by light quality. Nature, 423(6942), 881-885.

31. Chen, R., Hilson, P., Sedbrook, J., Rosen, E., Caspar, T., és Masson, P. H. (1998). The arabidopsis thaliana AGRAVITROPIC 1 gene encodes a component of the polar-auxintransport efflux carrier. Proc Natl Acad Sci U S A, 95(25), 15112-15117.

32. Chen, S., Wirthmueller, L., Stauber, J., Lory, N., Holtkotte, X., Leson, L. és mtsai. (2016). The functional divergence between SPA1 and SPA2 in Arabidopsis photomorphogenesis maps primarily to the respective N-terminal kinase-like domain. BMC Plant Biol, 16(1), 016-0854.

33. Chen, X., Yao, Q., Gao, X., Jiang, C., Harberd, N. P., és Fu, X. (2016). Shoot-to-Root Mobile Transcription Factor HY5 Coordinates Plant Carbon and Nitrogen Acquisition. Curr Biol, 26(5), 640-646.

34. Choudhury, S., Panda, P., Sahoo, L., és Panda, S. K. (2013). Reactive oxygen species signaling in plants under abiotic stress. Plant Signal Behav, 8(4), 20.

35. Christie, J. M., Arvai, A. S., Baxter, K. J., Heilmann, M., Pratt, A. J., O'Hara, A. és mtsai. (2012). Plant UVR8 photoreceptor senses UV-B by tryptophan-mediated disruption of cross-dimer salt bridges. Science, 335(6075), 1492-1496.

36. Christie, J. M., és Murphy, A. S. (2013). Shoot phototropism in higher plants: new light through old concepts. Am J Bot, 100(1), 35-46.

37. Cloix, C., és Jenkins, G. I. (2008). Interaction of the Arabidopsis UV-B-specific signaling component UVR8 with chromatin. Mol Plant, 1(1), 118-128. 
38. Cloix, C., Kaiserli, E., Heilmann, M., Baxter, K. J., Brown, B. A., O'Hara, A. és mtsai. (2012). C-terminal region of the UV-B photoreceptor UVR8 initiates signaling through interaction with the COP1 protein. Proc Natl Acad Sci U S A, 109(40), 16366-16370.

39. Clough, S. J., és Bent, A. F. (1998). Floral dip: a simplified method for Agrobacteriummediated transformation of Arabidopsis thaliana. Plant J, 16(6), 735-743.

40. Cluis, C. P., Mouchel, C. F., és Hardtke, C. S. (2004). The Arabidopsis transcription factor HY5 integrates light and hormone signaling pathways. Plant J, 38(2), 332-347.

41. Correll, M. J., Coveney, K. M., Raines, S. V., Mullen, J. L., Hangarter, R. P., és Kiss, J. Z. (2003). Phytochromes play a role in phototropism and gravitropism in Arabidopsis roots. Adv Space Res, 31(10), 2203-2210.

42. Cosio, C., és Dunand, C. (2009). Specific functions of individual class III peroxidase genes. J Exp Bot, 60(2), 391-408.

43. Davey, M. P., Susanti, N. I., Wargent, J. J., Findlay, J. E., Paul Quick, W., Paul, N. D. és mtsai. (2012). The UV-B photoreceptor UVR8 promotes photosynthetic efficiency in Arabidopsis thaliana exposed to elevated levels of UV-B. Photosynth Res, 114(2), 121131.

44. Day, T. A., Martin, G., és Vogelmann, T. C. (1993). Penetration of UV-B radiation in foliage: evidence that the epidermis behaves as a non-uniform filter. Plant, Cell és Environment, 16(6), 735-741.

45. Ding, Z., Galvan-Ampudia, C. S., Demarsy, E., Langowski, L., Kleine-Vehn, J., Fan, Y. és mtsai. (2011). Light-mediated polarization of the PIN3 auxin transporter for the phototropic response in Arabidopsis. Nat Cell Biol, 13(4), 447-452.

46. Dinh, S. T., Baldwin, I. T., és Galis, I. (2013). Multiple interactions of NaHER1 protein with abscisic acid signaling in Nicotiana attenuata plants. Plant Signal Behav, 8(11), 10.

47. Endo, M., Mochizuki, N., Suzuki, T., és Nagatani, A. (2007). CRYPTOCHROME2 in vascular bundles regulates flowering in Arabidopsis. Plant Cell, 19(1), 84-93.

48. Endo, M., Nakamura, S., Araki, T., Mochizuki, N., és Nagatani, A. (2005). Phytochrome B in the mesophyll delays flowering by suppressing FLOWERING LOCUS T expression in Arabidopsis vascular bundles. Plant Cell, 17(7), 1941-1952.

49. Esmon, C. A., Tinsley, A. G., Ljung, K., Sandberg, G., Hearne, L. B., és Liscum, E. (2006). A gradient of auxin and auxin-dependent transcription precedes tropic growth responses. Proc Natl Acad Sci U S A, 103(1), 236-241.

50. Fasano, R., Gonzalez, N., Tosco, A., Dal Piaz, F., Docimo, T., Serrano, R. és mtsai. (2014). Role of Arabidopsis UV RESISTANCE LOCUS 8 in plant growth reduction under osmotic stress and low levels of UV-B. Mol Plant, 7(5), 773-791.

51. Favory, J. J., Stec, A., Gruber, H., Rizzini, L., Oravecz, A., Funk, M. és mtsai. (2009). Interaction of COP1 and UVR8 regulates UV-B-induced photomorphogenesis and stress acclimation in Arabidopsis. Embo J, 28(5), 591-601.

52. Feher, B., Kozma-Bognar, L., Kevei, E., Hajdu, A., Binkert, M., Davis, S. J. és mtsai. (2011). Functional interaction of the circadian clock and UV RESISTANCE LOCUS 8controlled UV-B signaling pathways in Arabidopsis thaliana. Plant J, 67(1), 37-48.

53. Fierro, A. C., Leroux, O., De Coninck, B., Cammue, B. P., Marchal, K., Prinsen, E. és mtsai. (2015). Ultraviolet-B radiation stimulates downward leaf curling in Arabidopsis thaliana. Plant Physiol Biochem, 93, 9-17.

54. Fischer, B. B., Krieger-Liszkay, A., Hideg, E., Snyrychova, I., Wiesendanger, M., és Eggen, R. I. (2007). Role of singlet oxygen in chloroplast to nucleus retrograde signaling in Chlamydomonas reinhardtii. FEBS Lett, 581(29), 5555-5560.

55. Foyer, C. H., és Noctor, G. (2005). Redox homeostasis and antioxidant signaling: a metabolic interface between stress perception and physiological responses. Plant Cell, 17(7), 1866-1875.

56. Friml, J., Vieten, A., Sauer, M., Weijers, D., Schwarz, H., Hamann, T. és mtsai. (2003). Efflux-dependent auxin gradients establish the apical-basal axis of Arabidopsis. Nature, 426(6963), 147-153. 
57. Galweiler, L., Guan, C., Muller, A., Wisman, E., Mendgen, K., Yephremov, A. és mtsai. (1998). Regulation of polar auxin transport by AtPIN1 in Arabidopsis vascular tissue. Science, 282(5397), 2226-2230.

58. Ge, L., Peer, W., Robert, S., Swarup, R., Ye, S., Prigge, M. és mtsai. (2010). Arabidopsis ROOT UVB SENSITIVE2/WEAK AUXIN RESPONSE1 is required for polar auxin transport. Plant Cell, 22(6), 1749-1761.

59. Goyal, A., Szarzynska, B., és Fankhauser, C. (2013). Phototropism: at the crossroads of light-signaling pathways. Trends Plant Sci, 18(7), 393-401.

60. Gruber, H., Heijde, M., Heller, W., Albert, A., Seidlitz, H. K., és Ulm, R. (2010). Negative feedback regulation of UV-B-induced photomorphogenesis and stress acclimation in Arabidopsis. Proc Natl Acad Sci U S A, 107(46), 20132-20137.

61. Guo, H., Yang, H., Mockler, T. C., és Lin, C. (1998). Regulation of flowering time by Arabidopsis photoreceptors. Science, 279(5355), 1360-1363.

62. Hajdu, A., Adam, E., Sheerin, D. J., Dobos, O., Bernula, P., Hiltbrunner, A. és mtsai. (2015). High-level expression and phosphorylation of phytochrome B modulates flowering time in Arabidopsis. Plant J, 83(5), 794-805.

63. Halliday, K. J., Martinez-Garcia, J. F., és Josse, E. M. (2009). Integration of light and auxin signaling. Cold Spring Harb Perspect Biol, 1(6), 4.

64. Hanks, S. K., és Hunter, T. (1995). Protein kinases 6. The eukaryotic protein kinase superfamily: kinase (catalytic) domain structure and classification. Faseb J, 9(8), 576-596.

65. Harada, A., Sakai, T., és Okada, K. (2003). Phot1 and phot2 mediate blue light-induced transient increases in cytosolic Ca2+ differently in Arabidopsis leaves. Proc Natl Acad Sci U S A, 100(14), 8583-8588.

66. Hategan, L., Godza, B., Kozma-Bognar, L., Bishop, G. J., és Szekeres, M. (2014). Differential expression of the brassinosteroid receptor-encoding BRI1 gene in Arabidopsis. Planta, 239(5), 989-1001.

67. Hauvermale, A. L., Ariizumi, T., és Steber, C. M. (2012). Gibberellin signaling: a theme and variations on DELLA repression. Plant Physiol, 160(1), 83-92.

68. Hayes, S., Sharma, A., Fraser, D. P., Trevisan, M., Cragg-Barber, C. K., Tavridou, E. és mtsai. (2017). UV-B Perceived by the UVR8 Photoreceptor Inhibits Plant Thermomorphogenesis. Curr Biol, 27(1), 120-127.

69. Hayes, S., Velanis, C. N., Jenkins, G. I., és Franklin, K. A. (2014). UV-B detected by the UVR8 photoreceptor antagonizes auxin signaling and plant shade avoidance. Proc Natl Acad Sci U S A, 111(32), 11894-11899.

70. Heijde, M., Binkert, M., Yin, R., Ares-Orpel, F., Rizzini, L., Van De Slijke, E. és mtsai. (2013). Constitutively active UVR8 photoreceptor variant in Arabidopsis. Proc Natl Acad Sci U S A, 110(50), 20326-20331.

71. Heijde, M., és Ulm, R. (2013). Reversion of the Arabidopsis UV-B photoreceptor UVR8 to the homodimeric ground state. Proc Natl Acad Sci U S A, 110(3), 1113-1118.

72. Hideg, E., Jansen, M. A., és Strid, A. (2013). UV-B exposure, ROS, and stress: inseparable companions or loosely linked associates? Trends Plant Sci, 18(2), 107-115.

73. Hideg, É., és Strid, A. (2016). The effects of UV-B on the biochemistry and metabolism in plants. $U V-B$ radiation and plant growth and development. Wallingford, UK: CABI Publishing.

74. Hiltbrunner, A., Tscheuschler, A., Viczian, A., Kunkel, T., Kircher, S., és Schafer, E. (2006). FHY1 and FHL act together to mediate nuclear accumulation of the phytochrome A photoreceptor. Plant Cell Physiol, 47(8), 1023-1034.

75. Hiltbrunner, A., Viczian, A., Bury, E., Tscheuschler, A., Kircher, S., Toth, R. és mtsai. (2005). Nuclear accumulation of the phytochrome A photoreceptor requires FHY1. Curr Biol, 15(23), 2125-2130.

76. Hollosy, F. (2002). Effects of ultraviolet radiation on plant cells. Micron, 33(2), 179-197.

77. Hornitschek, P., Kohnen, M. V., Lorrain, S., Rougemont, J., Ljung, K., Lopez-Vidriero, I. és mtsai. (2012). Phytochrome interacting factors 4 and 5 control seedling growth in changing light conditions by directly controlling auxin signaling. Plant J, 71(5), 699-711. 
78. Huala, E., Oeller, P. W., Liscum, E., Han, I. S., Larsen, E., és Briggs, W. R. (1997). Arabidopsis NPH1: a protein kinase with a putative redox-sensing domain. Science, 278(5346), 2120-2123.

79. Huang, X., Ouyang, X., Yang, P., Lau, O. S., Chen, L., Wei, N. és mtsai. (2013). Conversion from CUL4-based COP1-SPA E3 apparatus to UVR8-COP1-SPA complexes underlies a distinct biochemical function of COP1 under UV-B. Proc Natl Acad Sci U S A, $110(41), 16669-16674$.

80. Huang, X., Ouyang, X., Yang, P., Lau, O. S., Li, G., Li, J. és mtsai. (2012). Arabidopsis FHY3 and HY5 positively mediate induction of COP1 transcription in response to photomorphogenic UV-B light. Plant Cell, 24(11), 4590-4606.

81. Huang, X., Yang, P., Ouyang, X., Chen, L., és Deng, X. W. (2014). Photoactivated UVR8COP1 module determines photomorphogenic UV-B signaling output in Arabidopsis. PLoS Genet, 10(3).

82. Hutin, C., Nussaume, L., Moise, N., Moya, I., Kloppstech, K., és Havaux, M. (2003). Early light-induced proteins protect Arabidopsis from photooxidative stress. Proc Natl Acad Sci U S A, 100(8), 4921-4926.

83. Hutzler, P., Fischbach, R., Heller, W., Jungblut, T. P., Reuber, S., Schmitz, R. és mtsai. (1998). Tissue localization of phenolic compounds in plants by confocal laser scanning microscopy. Journal of Experimental Botany, 49(323), 953-965.

84. Iino, M. (1990). Phototropism: mechanisms and ecological implications. Plant, Cell és Environment, 13(7), 633-650.

85. Inskeep, W. P., és Bloom, P. R. (1985). Extinction coefficients of chlorophyll a and B in n,n-dimethylformamide and 80\% acetone. Plant Physiol, 77(2), 483-485.

86. Ivanov, B., Mubarakshina, M., és Khorobrykh, S. (2007). Kinetics of the plastoquinone pool oxidation following illumination Oxygen incorporation into photosynthetic electron transport chain. FEBS Lett, 581(7), 1342-1346.

87. Janoudi, A. K., Gordon, W. R., Wagner, D., Quail, P., és Poff, K. L. (1997). Multiple phytochromes are involved in red-light-induced enhancement of first-positive phototropism in Arabidopsis thaliana. Plant Physiol, 113(3), 975-979.

88. Jansen, M. A., van den Noort, R. E., Tan, M. Y., Prinsen, E., Lagrimini, L. M., és Thorneley, R. N. (2001). Phenol-oxidizing peroxidases contribute to the protection of plants from ultraviolet radiation stress. Plant Physiol, 126(3), 1012-1023.

89. Jenkins, G. I. (2009). Signal transduction in responses to UV-B radiation. Annu Rev Plant Biol, 60, 407-431.

90. Jenkins, G. I., Long, J. C., Wade, H. K., Shenton, M. R., és Bibikova, T. N. (2001). UV and blue light signalling: pathways regulating chalcone synthase gene expression in Arabidopsis. New Phytologist, 151(1), 121-131.

91. Jordan, E. T., Hatfield, P. M., Hondred, D., Talon, M., Zeevaart, J. A., és Vierstra, R. D. (1995). Phytochrome A overexpression in transgenic tobacco. Correlation of dwarf phenotype with high concentrations of phytochrome in vascular tissue and attenuated gibberellin levels. Plant Physiol, 107(3), 797-805.

92. Kaiserli, E., és Jenkins, G. I. (2007). UV-B promotes rapid nuclear translocation of the Arabidopsis UV-B specific signaling component UVR8 and activates its function in the nucleus. Plant Cell, 19(8), 2662-2673.

93. Kami, C., Hersch, M., Trevisan, M., Genoud, T., Hiltbrunner, A., Bergmann, S. és mtsai. (2012). Nuclear phytochrome A signaling promotes phototropism in Arabidopsis. Plant Cell, 24(2), 566-576.

94. Kevei, E., Schafer, E., és Nagy, F. (2007). Light-regulated nucleo-cytoplasmic partitioning of phytochromes. J Exp Bot, 58(12), 3113-3124.

95. Kim, B., Jeong, Y. J., Corvalan, C., Fujioka, S., Cho, S., Park, T. és mtsai. (2014). Darkness and gulliver2/phyB mutation decrease the abundance of phosphorylated BZR1 to activate brassinosteroid signaling in Arabidopsis. Plant J, 77(5), 737-747.

96. Kim, J., Song, K., Park, E., Kim, K., Bae, G., és Choi, G. (2016). Epidermal Phytochrome B Inhibits Hypocotyl Negative Gravitropism Non-Cell-Autonomously. Plant Cell, 28(11), 2770-2785. 
97. Kim, S., Mochizuki, N., Deguchi, A., Nagano, A. J., Suzuki, T., és Nagatani, A. (2018). Auxin contributes to the intra-organ regulation of gene expression in response to shade. Plant Physiology.

98. Kirchenbauer, D., Viczian, A., Adam, E., Hegedus, Z., Klose, C., Leppert, M. és mtsai. (2016). Characterization of photomorphogenic responses and signaling cascades controlled by phytochrome-A expressed in different tissues. New Phytol, 211(2), 584-598.

99. Kliebenstein, D. J., Lim, J. E., Landry, L. G., és Last, R. L. (2002). Arabidopsis UVR8 regulates ultraviolet-B signal transduction and tolerance and contains sequence similarity to human regulator of chromatin condensation 1. Plant Physiol, 130(1), 234-243.

100. Koncz, C., Martini, N., Szabados, L., Hrouda, M., Bachmair, A., és Schell, J. (1994). Specialized vectors for gene tagging and expression studies. Gelvin SB, Schilperoort RA (eds) Plant Molecular Biology Manual. Springer, Dordrecht.

101. Kozuka, T., Kong, S. G., Doi, M., Shimazaki, K., és Nagatani, A. (2011). Tissueautonomous promotion of palisade cell development by phototropin 2 in Arabidopsis. Plant Cell, 23(10), 3684-3695.

102. Krasylenko, Y. A., Yemets, A. I., Sheremet, Y. A., és Blume, Y. B. (2012). Nitric oxide as a critical factor for perception of UV-B irradiation by microtubules in Arabidopsis. Physiol Plant, 145(4), 505-515.

103. Krieger-Liszkay, A., Kos, P. B., és Hideg, E. (2011). Superoxide anion radicals generated by methylviologen in photosystem I damage photosystem II. Physiol Plant, 142(1), 17-25.

104. Ksas, B., Becuwe, N., Chevalier, A., és Havaux, M. (2015). Plant tolerance to excess light energy and photooxidative damage relies on plastoquinone biosynthesis. Scientific Reports, 5, 10919.

105. Lau, O. S., és Deng, X. W. (2012). The photomorphogenic repressors COP1 and DET1: 20 years later. Trends Plant Sci, 17(10), 584-593.

106. Laubinger, S., Fittinghoff, K., és Hoecker, U. (2004). The SPA quartet: a family of WDrepeat proteins with a central role in suppression of photomorphogenesis in arabidopsis. Plant Cell, 16(9), 2293-2306.

107. Leivar, P., Monte, E., Cohn, M. M., és Quail, P. H. (2012). Phytochrome signaling in green Arabidopsis seedlings: impact assessment of a mutually negative phyB-PIF feedback loop. Mol Plant, 5(3), 734-749.

108. Li, H., Li, Y., Deng, H., Sun, X., Wang, A., Tang, X. és mtsai. (2018). Tomato UV-B receptor SIUVR8 mediates plant acclimation to UV-B radiation and enhances fruit chloroplast development via regulating SIGLK2. Sci Rep, 8(1), 018-24309.

109. Li, J., Li, G., Wang, H., és Wang Deng, X. (2011). Phytochrome signaling mechanisms. Arabidopsis Book, 9(10), 29.

110. Li, K., Yu, R., Fan, L. M., Wei, N., Chen, H., és Deng, X. W. (2016). DELLA-mediated PIF degradation contributes to coordination of light and gibberellin signalling in Arabidopsis. Nat Commun, 7(11868).

111. Li, Q. F., \& He, J. X. (2016). BZR1 Interacts with HY5 to Mediate Brassinosteroid- and Light-Regulated Cotyledon Opening in Arabidopsis in Darkness. Mol Plant, 9(1), 113-125.

112. Liang, T., Mei, S., Shi, C., Yang, Y., Peng, Y., Ma, L. és mtsai. (2018). UVR8 Interacts with BES1 and BIM1 to Regulate Transcription and Photomorphogenesis in Arabidopsis. Dev Cell, 44(4), 512-523.

113. Lichtenthaler, H. K. (1998). The stress concept in plants: an introduction. Ann N Y Acad Sci, 851, 187-198.

114. Lin, C., és Shalitin, D. (2003). Cryptochrome structure and signal transduction. Annu Rev Plant Biol, 54, 469-496.

115. Liu, Q., Wang, Q., Deng, W., Wang, X., Piao, M., Cai, D. és mtsai. (2017). Molecular basis for blue light-dependent phosphorylation of Arabidopsis cryptochrome 2. Nature Communications, 8, 15234 .

116. Lorrain, S., Allen, T., Duek, P. D., Whitelam, G. C., és Fankhauser, C. (2008). Phytochrome-mediated inhibition of shade avoidance involves degradation of growthpromoting bHLH transcription factors. Plant J, 53(2), 312-323. 
117. Luo, X. M., Lin, W. H., Zhu, S., Zhu, J. Y., Sun, Y., Fan, X. Y. és mtsai. (2010). Integration of light- and brassinosteroid-signaling pathways by a GATA transcription factor in Arabidopsis. Dev Cell, 19(6), 872-883.

118. Ma, L., Li, J., Qu, L., Hager, J., Chen, Z., Zhao, H. és mtsai. (2001). Light control of Arabidopsis development entails coordinated regulation of genome expression and cellular pathways. Plant Cell, 13(12), 2589-2607.

119. Mackerness, John, C. F., Jordan, B., és Thomas, B. (2001). Early signaling components in ultraviolet-B responses: distinct roles for different reactive oxygen species and nitric oxide. FEBS Lett, 489(2-3), 237-242.

120. Makde, R. D., England, J. R., Yennawar, H. P., és Tan, S. (2010). Structure of RCC1 chromatin factor bound to the nucleosome core particle. Nature, 467(7315), 562-566.

121. Marchant, A., Kargul, J., May, S. T., Muller, P., Delbarre, A., Perrot-Rechenmann, C. és mtsai. (1999). AUX1 regulates root gravitropism in Arabidopsis by facilitating auxin uptake within root apical tissues. Embo J, 18(8), 2066-2073.

122. Mazza, C. A., és Ballare, C. L. Photoreceptors UVR8 and phytochrome B cooperate to optimize plant growth and defense in patchy canopies: New Phytol. 2015 Jul;207(1):4-9. doi: 10.1111/nph.13332. Epub 2015 Feb 6.

123. Mitra, A., Choi, H. K., és An, G. (1989). Structural and functional analyses of Arabidopsis thaliana chlorophyll a/b-binding protein (cab) promoters. Plant Mol Biol, 12(2), 169-179.

124. Mittler, R. (2002). Oxidative stress, antioxidants and stress tolerance. Trends Plant Sci, 7(9), 405-410.

125. Nagy, F., és Schafer, E. (2002). Phytochromes control photomorphogenesis by differentially regulated, interacting signaling pathways in higher plants. Annu Rev Plant Biol, 53, 329-355.

126. Nakamichi, N., Kita, M., Ito, S., Yamashino, T., és Mizuno, T. (2005). PSEUDORESPONSE REGULATORS, PRR9, PRR7 and PRR5, together play essential roles close to the circadian clock of Arabidopsis thaliana. Plant Cell Physiol, 46(5), 686-698.

127. Napier, R. M., David, K. M., és Perrot-Rechenmann, C. (2002). A short history of auxinbinding proteins. Plant Mol Biol, 49(3-4), 339-348.

128. Navari-Izzo, F., Pinzino, C., Quartacci, M. F., és Sgherri, C. L. (1999). Superoxide and hydroxyl radical generation, and superoxide dismutase in PSII membrane fragments from wheat. Free Radic Res, 31(9), S3-9.

129. Nick, P., Ehmann, B., Furuya, M., és Schafer, E. (1993). Cell Communication, Stochastic Cell Responses, and Anthocyanin Pattern in Mustard Cotyledons. Plant Cell, 5(5), 541552.

130. Nito, K., Kajiyama, T., Unten-Kobayashi, J., Fujii, A., Mochizuki, N., Kambara, H. és mtsai. (2015). Spatial Regulation of the Gene Expression Response to Shade in Arabidopsis Seedlings. Plant Cell Physiol, 56(7), 1306-1319.

131. Nogues, S., Allen, D. J., Morison, J. I., és Baker, N. R. (1999). Characterization of stomatal closure caused by ultraviolet-B radiation. Plant Physiol, 121(2), 489-496.

132. O'Hara, A., és Jenkins, G. I. (2012). In vivo function of tryptophans in the Arabidopsis UV-B photoreceptor UVR8. Plant Cell, 24(9), 3755-3766.

133. Oh, E., Zhu, J. Y., és Wang, Z. Y. (2012). Interaction between BZR1 and PIF4 integrates brassinosteroid and environmental responses. Nat Cell Biol, 14(8), 802-809.

134. Oravecz, A., Baumann, A., Mate, Z., Brzezinska, A., Molinier, J., Oakeley, E. J. és mtsai. (2006). CONSTITUTIVELY PHOTOMORPHOGENIC1 is required for the UV-B response in Arabidopsis. Plant Cell, 18(8), 1975-1990.

135. Osterlund, M. T., Hardtke, C. S., Wei, N., és Deng, X. W. (2000). Targeted destabilization of HY5 during light-regulated development of Arabidopsis. Nature, 405(6785), 462-466.

136. Oyama, T., Shimura, Y., és Okada, K. (1997). The Arabidopsis HY5 gene encodes a bZIP protein that regulates stimulus-induced development of root and hypocotyl. Genes és Development, 11(22), 2983-2995. 
137. Peer, W. A., Brown, D. E., Tague, B. W., Muday, G. K., Taiz, L., és Murphy, A. S. (2001). Flavonoid accumulation patterns of transparent testa mutants of arabidopsis. Plant Physiol, 126(2), 536-548.

138. Peer, W. A., és Murphy, A. S. (2007). Flavonoids and auxin transport: modulators or regulators? Trends Plant Sci, 12(12), 556-563.

139. Pietta, P. G. (2000). Flavonoids as antioxidants. J Nat Prod, 63(7), 1035-1042.

140. Podolec, R., és Ulm, R. (2018). Photoreceptor-mediated regulation of the COP1/SPA E3 ubiquitin ligase. Current opinion in plant biology, 45, 18-25.

141. Porra, R. J., Thompson, W. A., és Kriedemann, P. E. (1989). Determination of accurate extinction coefficients and simultaneous equations for assaying chlorophylls $\mathrm{a}$ and $\mathrm{b}$ extracted with four different solvents: verification of the concentration of chlorophyll standards by atomic absorption spectroscopy. Biochimica et Biophysica Acta (BBA) Bioenergetics, 975(3), 384-394.

142. Preuten, T., Hohm, T., Bergmann, S., és Fankhauser, C. (2013). Defining the site of light perception and initiation of phototropism in Arabidopsis. Curr Biol, 23(19), 1934-1938.

143. Quint, M., és Gray, W. M. (2006). Auxin signaling. Current opinion in plant biology, 9(5), 448-453.

144. Rakitina, T. Y., Rakitin, V. Y., Vlasov, P. V., és Prudnikova, O. N. (2004). Effect of ABA on the UV-B-Induced Ethylene Evolution by the etr and ctr Mutants of Arabidopsis thaliana. [journal article]. Russian Journal of Plant Physiology, 51(5), 663-668.

145. Rizzini, L., Favory, J. J., Cloix, C., Faggionato, D., O'Hara, A., Kaiserli, E. és mtsai. (2011). Perception of UV-B by the Arabidopsis UVR8 protein. Science, 332(6025), 103106.

146. Sakai, T., Kagawa, T., Kasahara, M., Swartz, T. E., Christie, J. M., Briggs, W. R. és mtsai. (2001). Arabidopsis nph1 and npl1: blue light receptors that mediate both phototropism and chloroplast relocation. Proc Natl Acad Sci U S A, 98(12), 6969-6974.

147. Sakamoto, K., és Briggs, W. R. (2002). Cellular and subcellular localization of phototropin 1. Plant Cell, 14(8), 1723-1735.

148. Sambrook, J. (2001). Molecular cloning : a laboratory manual: Third edition. Cold Spring Harbor, N.Y. : Cold Spring Harbor Laboratory Press, [2001] (C2001.

149. Savaldi-Goldstein, S., Peto, C., és Chory, J. (2007). The epidermis both drives and restricts plant shoot growth. Nature, 446(7132), 199-202.

150. Schäfer, E., és Bowler, C. (2002). Phytochrome-mediated photoperception and signal transduction in higher plants. EMBO Reports, 3(11), 1042-1048.

151. Schnitzler, J.-P., Jungblut, T. P., Heller, W., KÖFferlein, M., Hutzler, P., Heinzmann, U. és mtsai. (1996). Tissue localization of u.v.-B-screening pigments and of chalcone synthase mRNA in needles of Scots pine seedlings. New Phytologist, 132(2), 247-258.

152. Sessions, A., Weigel, D., és Yanofsky, M. F. (1999). The Arabidopsis thaliana MERISTEM LAYER 1 promoter specifies epidermal expression in meristems and young primordia. Plant J, 20(2), 259-263.

153. Shalitin, D., Yu, X., Maymon, M., Mockler, T., és Lin, C. (2003). Blue light-dependent in vivo and in vitro phosphorylation of Arabidopsis cryptochrome 1. Plant Cell, 15(10), 2421-2429.

154. Shigeto, J., és Tsutsumi, Y. (2016). Diverse functions and reactions of class III peroxidases. New Phytol, 209(4), 1395-1402.

155. Sibout, R., Sukumar, P., Hettiarachchi, C., Holm, M., Muday, G. K., és Hardtke, C. S. (2006). Opposite root growth phenotypes of hy5 versus hy5 hyh mutants correlate with increased constitutive auxin signaling. PLoS Genet, 2(11), 0020202.

156. Smith, H., és Whitelam, G. C. (1997). The shade avoidance syndrome: multiple responses mediated by multiple phytochromes. Plant, Cell és Environment, 20(6), 840-844.

157. Srivastava, A. C., Ganesan, S., Ismail, I. O., és Ayre, B. G. (2008). Functional characterization of the Arabidopsis AtSUC2 Sucrose/H+ symporter by tissue-specific complementation reveals an essential role in phloem loading but not in long-distance transport. Plant Physiol, 148(1), 200-211. 
158. Stracke, R., Favory, J. J., Gruber, H., Bartelniewoehner, L., Bartels, S., Binkert, M. és mtsai. (2010). The Arabidopsis bZIP transcription factor HY5 regulates expression of the PFG1/MYB12 gene in response to light and ultraviolet-B radiation. Plant Cell Environ, 33(1), 88-103.

159. Sullivan, J. A., és Deng, X. W. (2003). From seed to seed: the role of photoreceptors in Arabidopsis development. Dev Biol, 260(2), 289-297.

160. Sun, J., Qi, L., Li, Y., Zhai, Q., és Li, C. (2013). PIF4 and PIF5 transcription factors link blue light and auxin to regulate the phototropic response in Arabidopsis. Plant Cell, 25(6), 2102-2114.

161. Sun, z., Wen, C., Chen, Z., Zhang, Q. a., Fang, L., Li, J. és mtsai. (2011). A role for Ethylene-Insensitive 2 gene in the regulation of the ultraviolet-B response in Arabidopsis (Vol. 33).

162. Tao, Y., Ferrer, J. L., Ljung, K., Pojer, F., Hong, F., Long, J. A. és mtsai. (2008). Rapid synthesis of auxin via a new tryptophan-dependent pathway is required for shade avoidance in plants. Cell, 133(1), 164-176.

163. Tilbrook, K., Arongaus, A. B., Binkert, M., Heijde, M., Yin, R., és Ulm, R. (2013). The UVR8 UV-B Photoreceptor: Perception, Signaling and Response. Arabidopsis Book, 11(11).

164. Tiwari, S. B., Wang, X. J., Hagen, G., és Guilfoyle, T. J. (2001). AUX/IAA proteins are active repressors, and their stability and activity are modulated by auxin. Plant Cell, 13(12), 2809-2822.

165. Toledo-Ortiz, G., Johansson, H., Lee, K. P., Bou-Torrent, J., Stewart, K., Steel, G. és mtsai. (2014). The HY5-PIF regulatory module coordinates light and temperature control of photosynthetic gene transcription. PLoS Genet, 10(6).

166. Tossi, V., Lamattina, L., és Cassia, R. (2009). An increase in the concentration of abscisic acid is critical for nitric oxide-mediated plant adaptive responses to UV-B irradiation. New Phytol, 181(4), 871-879.

167. Uchida, N., Lee, J. S., Horst, R. J., Lai, H. H., Kajita, R., Kakimoto, T. és mtsai. (2012). Regulation of inflorescence architecture by intertissue layer ligand-receptor communication between endodermis and phloem. Proc Natl Acad Sci U S A, 109(16), 6337-6342.

168. Ulm, R., Baumann, A., Oravecz, A., Mate, Z., Adam, E., Oakeley, E. J. és mtsai. (2004). Genome-wide analysis of gene expression reveals function of the bZIP transcription factor HY5 in the UV-B response of Arabidopsis. Proc Natl Acad Sci U S A, 101(5), 1397-1402.

169. Ulmasov, T., Hagen, G., és Guilfoyle, T. J. (1997). ARF1, a transcription factor that binds to auxin response elements. Science, 276(5320), 1865-1868.

170. Vandenbussche, F., Habricot, Y., Condiff, A. S., Maldiney, R., Van der Straeten, D., és Ahmad, M. (2007). HY5 is a point of convergence between cryptochrome and cytokinin signalling pathways in Arabidopsis thaliana. Plant J, 49(3), 428-441.

171. Vandenbussche, F., Petrasek, J., Zadnikova, P., Hoyerova, K., Pesek, B., Raz, V. és mtsai. (2010). The auxin influx carriers AUX1 and LAX3 are involved in auxin-ethylene interactions during apical hook development in Arabidopsis thaliana seedlings. Development, 137(4), 597-606.

172. Vandenbussche, F., Tilbrook, K., Fierro, A. C., Marchal, K., Poelman, D., Van Der Straeten, D. és mtsai. (2014). Photoreceptor-mediated bending towards UV-B in Arabidopsis. Mol Plant, 7(6), 1041-1052.

173. Vandenbussche, F., és Van Der Straeten, D. (2014). Differential accumulation of ELONGATED HYPOCOTYL5 correlates with hypocotyl bending to ultraviolet-B light. Plant Physiol, 166(1), 40-43.

174. Vandenbussche, F., Yu, N., Li, W., Vanhaelewyn, L., Hamshou, M., Van Der Straeten, D. és mtsai. (2018). An ultraviolet B condition that affects growth and defense in Arabidopsis. Plant Sci, 268, 54-63.

175. Vanhaelewyn, L., Prinsen, E., Van Der Straeten, D., és Vandenbussche, F. (2016). Hormone-controlled UV-B responses in plants. J Exp Bot, 67(15), 4469-4482. 
176. Vanhaelewyn, L., Schumacher, P., Poelman, D., Fankhauser, C., Van Der Straeten, D., és Vandenbussche, F. (2016). REPRESSOR OF ULTRAVIOLET-B PHOTOMORPHOGENESIS function allows efficient phototropin mediated ultraviolet-B phototropism in etiolated seedlings. Plant Sci, 252, 215-221.

177. Wade, H. K., Bibikova, T. N., Valentine, W. J., és Jenkins, G. I. (2001). Interactions within a network of phytochrome, cryptochrome and UV-B phototransduction pathways regulate chalcone synthase gene expression in Arabidopsis leaf tissue. Plant J, 25(6), 675685.

178. Wan, J., Zhang, P., Wang, R., Sun, L., Wang, W., Zhou, H. és mtsai. (2018). UV-B Radiation Induces Root Bending Through the Flavonoid-Mediated Auxin Pathway in Arabidopsis. Front Plant Sci, 9(618).

179. Wan, Y. L., Eisinger, W., Ehrhardt, D., Kubitscheck, U., Baluska, F., és Briggs, W. (2008). The subcellular localization and blue-light-induced movement of phototropin 1GFP in etiolated seedlings of Arabidopsis thaliana. Mol Plant, 1(1), 103-117.

180. Wargent, J. J., Gegas, V. C., Jenkins, G. I., Doonan, J. H., és Paul, N. D. (2009). UVR8 in Arabidopsis thaliana regulates multiple aspects of cellular differentiation during leaf development in response to ultraviolet B radiation. New Phytol, 183(2), 315-326.

181. Weller, J. L., Hecht, V., Vander Schoor, J. K., Davidson, S. E., és Ross, J. J. (2009). Light regulation of gibberellin biosynthesis in pea is mediated through the COP1/HY5 pathway. Plant Cell, 21(3), 800-813.

182. Wellmann, E. (1976). SPECIFIC ULTRAVIOLET EFFECTS IN PLANT MORPHOGENESIS. Photochemistry and Photobiology, 24(6), 659-660.

183. Wolf, I., Kircher, S., Fejes, E., Kozma-Bognar, L., Schafer, E., Nagy, F. és mtsai. (2011). Light-regulated nuclear import and degradation of Arabidopsis phytochrome-A N-terminal fragments. Plant Cell Physiol, 52(2), 361-372.

184. Woodward, A. W., és Bartel, B. (2005). Auxin: regulation, action, and interaction. Ann Bot, 95(5), 707-735.

185. Xu, C., és Min, J. (2011). Structure and function of WD40 domain proteins. Protein Cell, 2(3), 202-214.

186. Yang, Y., Liang, T., Zhang, L., Shao, K., Gu, X., Shang, R. és mtsai. (2018). UVR8 interacts with WRKY36 to regulate HY5 transcription and hypocotyl elongation in Arabidopsis. Nat Plants, 4(2), 98-107.

187. Yanykin, D. V., Khorobrykh, A. A., Khorobrykh, S. A., és Klimov, V. V. (2010). Photoconsumption of molecular oxygen on both donor and acceptor sides of photosystem II in Mn-depleted subchloroplast membrane fragments. Biochim Biophys Acta, 4, 516-523.

188. Yin, R., Skvortsova, M. Y., Loubery, S., és Ulm, R. (2016). COP1 is required for UV-Binduced nuclear accumulation of the UVR8 photoreceptor. Proc Natl Acad Sci U S A, $113(30), 12$.

189. Yokawa, K., és Baluska, F. (2015). Pectins, ROS homeostasis and UV-B responses in plant roots. Phytochemistry, 112, 80-83.

190. Yu, X., Klejnot, J., Zhao, X., Shalitin, D., Maymon, M., Yang, H. és mtsai. (2007). Arabidopsis cryptochrome 2 completes its posttranslational life cycle in the nucleus. Plant Cell, 19(10), 3146-3156.

191. Yu, Y., Wang, J., Zhang, Z., Quan, R., Zhang, H., Deng, X. W. és mtsai. (2013). Ethylene promotes hypocotyl growth and HY5 degradation by enhancing the movement of COP1 to the nucleus in the light. PLoS Genet, 9(12), 12.

192. Zhong, S., Shi, H., Xue, C., Wang, L., Xi, Y., Li, J. és mtsai. (2012). A molecular framework of light-controlled phytohormone action in Arabidopsis. Curr Biol, 22(16), 1530-1535.

193. Zhu, D., Maier, A., Lee, J. H., Laubinger, S., Saijo, Y., Wang, H. és mtsai. (2008). Biochemical characterization of Arabidopsis complexes containing CONSTITUTIVELY PHOTOMORPHOGENIC1 and SUPPRESSOR OF PHYA proteins in light control of plant development. Plant Cell, 20(9), 2307-2323.

194. Ziegler, T., és Möglich, A. (2015). Photoreceptor engineering. Frontiers in Molecular Biosciences, 2, 30 . 


\section{KÖSZÖNETNYILVÁNÍTÁS}

A dolgozatban bemutatott kísérletek döntő többségét a Magyar Tudományos Akadémia Szegedi Biológiai Kutatóközpontjának Növénybiológiai Intézetében, a Foto- és Kronobiológiai Csoport tagjaként végeztem. Köszönöm volt és jelenlegi csoportvezetőimnek, Dr. Nagy Ferencnek és Dr. Kozma-Bognár Lászlónak a jelentős anyagi támogatást, valamint a szakmai segítséget, amellyel végig segítették munkámat. Köszönettel tartozok Dr. Ormos Pál volt- és Dr. Nagy Ferenc jelenlegi főigazgató, valamint Dr. Vass Imre igazgató uraknak, hogy a Szegedi Biológiai Központban biztosították munkámhoz a feltételeket. Dolgozatom a GINOP-2.3.2-15-2016-00001, GINOP-2.3.2-15-2016-00015, valamint a GINOP-2.3.2-15-2016-00032 számú pályázatok nélkül nem készülhetett volna el. Munkámat az MTA Fiatal Kutató ösztöndíjjal segítette.

Köszönöm témavezetőimnek, Dr. Nagy Ferencnek és Dr. Viczián Andrásnak, hogy a csoportban eltöltött évek alatt figyelemmel kísérték munkámat, szakmai segítséget nyújtottak, mindvégig bátorítottak közös céljaink elérése érdekében. Külön köszönöm Dr. Viczián Andrásnak a dolgozatommal kapcsolatos minden részletre kiterjedő és lelkiismeretes javítási munkát, javaslatait. Külön köszönöm azt a lehetőséget, hogy Dr. Dominique Van Der Straeten (Ghent University, Belgium) csoportjával közös pályázatának köszönhetően a dolgozat témájában számos új eredmény születhetett, genti tartózkodásom ideje alatt értékes szakmai tapasztalatokra és új ismeretségekre tehettem szert.

Köszönöm Dr. Dominique Van Der Straetennek, hogy kísérleteink egy részét kooperációs pályázatunk keretében laboratóriumában végezhettem. Az ottani munkában Dr. Filip Vandenbussche és Lucas Vanhaelewyn nyújtott szakmai segítséget. Külön köszönöm Lucas Vanhaelewynnek a barátságos fogadtatást, segítőkészséget, a feledhetetlen hangulatú együtt töltött időt, valamint a dolgozatom megírásához nyújtott rengeteg segítséget.

Hálásan köszönök mindent a Foto- és Kronobiológiai Csoport minden egyes volt és jelenlegi tagjának, akik munkámat segítették. Kiemelten köszönöm Dr. Ádám Évának, Dr. KozmaBognárné Dr. Hajdu Anitának és Dr. Kozma-Bognár Lászlónak a rengeteg elméleti és gyakorlati segítséget, amit az évek alatt nyújtottak. Mindenkinek köszönöm a segítséget, aki dolgozatom hibajavításában részt vett. Hálásan köszönöm Mártinak, Györgyinek, Hédinek, és Gabinak a vidám hangulatú munkanapokat, a növénynevelésben és a kísérletek előkészítésében nyújtott nélkülözhetetlen segítséget.

Nagyon köszönöm Dr. Kereszt Attilának a házi védésre elkészített precíz és lelkiismeretes bírálati munkát, értékes észrevételeit, amik hozzájárultak a dolgozatom végleges formájának kialakulásához. 
Köszönöm bírálóimnak, hogy a nagy védésre elkészítették dolgozatom bírálatát, köszönöm a Bizottság minden tagjának, hogy védésem lebonyolításához munkájukkal hozzájárultak.

Köszönöm minden biológus kollégámnak, egyetemi csoporttársaimnak, hogy velük tartalmas és hasznos beszélgetéseket ejthettem meg a kutatói élettel és a fokozatszerzés folyamatával kapcsolatban. Hálás vagyok minden irodai dolgozónak, amiért hivatalos ügyeim lebonyolításában mindig számíthattam segítségükre. Köszönöm a technikai dolgozóknak, hogy mindig tiszta, rendezett környezetben végezhettem munkámat.

Nagyon köszönöm családomnak, barátaimnak a kitartó érdeklődést, szüleimnek a támogatást és minden egyéb segítséget, amik hozzásegítettek a Ph.D. fokozat megszerzéséhez. Testvéremnek, Bernula Dórának mindezek mellett a dolgozatom hibajavításában nyújtott segítségéért külön is nagyon hálás vagyok. Végül, de nem utolsó sorban feleségemnek, Áginak is őszintén köszönöm a dolgozatom ellenőrzését, az évek alatt tanúsított kitartó támogatást és a szeretetteljes családi légkör megteremtését, amik nélkül ez a dolgozat nem jöhetett volna létre. 


\section{Nyilatkozat}

Mint az alábbi közlemény felelős szerzője igazolom, hogy Bernula Péter Ph.D. jelölt jelentős mértékben hozzájárult az alábbi tudományos publikáció létrehozásához és tézisében közölt eredményeit más Ph.D. értekezésben nem használjuk fel:

Bernula P., Crocco C. D., Arongaus A. B., Ulm R., Nagy F., Viczián A. (2017).

Expression of the UVR8 photoreceptor in different tissues reveals tissue autonomous features of UV-B signalling. Plant Cell Environ. Jul;40(7), 1104-1114.

doi: 10.1111/pce.12904. Epub 2017 Mar 27. PMID: 28058744

Szeged, 2018. szeptember 12.

Dr. Viczián András

tudományos fömunkatárs

MTA-SZBK, Növénybiológiai Intézet 